P.S.

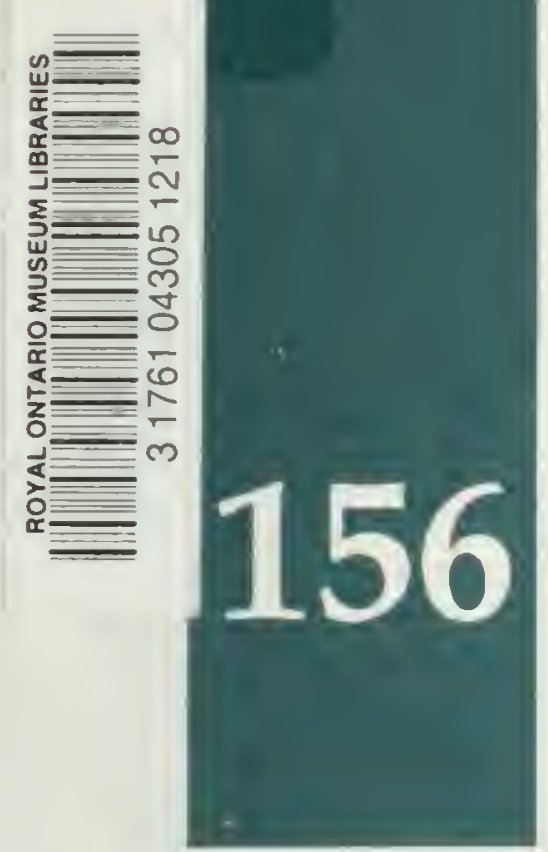

CONODONTS OF THE LOWER BORDER GROUP AND EQUIVALENT STRATA (LOWER CARBONIFEROUS) IN NORTHERN CUMBRIA AND THE SCOTTISH BORDERS, U.K.

Mark A. Purnell

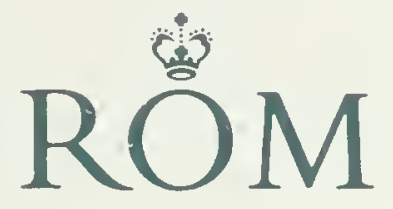


Digitized by the Internet Archive in 2011 with funding from Royal Ontario Museum 


\section{ROYAL ONTARIO MUSEUM \\ LIFE SCIENCES CONTRIBUTIONS \\ 156 \\ CONODONTS OF THE LOWER BORDER GROUP AND EQUIVALENT STRATA (LOWER CARBONIFEROUS) IN NORTHERN CUMBRIA AND THE SCOTTISH BORDERS, U.K.}

Mark A. Purnell

RỒM 
(C) 1992 Royal Ontario Museum

All rights reserved. No part of this publication may be reproduced, stored in a retrieval system or data base, or transmitted, in any form or by any means, electronic, mechanical, photocopying, or otherwise, without the prior written consent of the publisher.

First published in 1992 by the Royal Ontario Museum, 100 Queen's Park, Toronto, Ontario M5S 2C6.

Publication date: 1 December 1992

ISBN: 0-88854-405-7

ISSN: 0384-8159

\section{Canadian Cataloguing in Publication Data}

Purnell, Mark A., 1964-

Conodonts of the Lower Border Group and

equivalent strata (Lower Carboniferous) in Northern

Cumbria and the Scottish Borders, U.K.

(Life Sciences Contribution ; no. 156)

Includes bibliographical references.

ISBN 0-88854-405-7

1. Conodonts - Cumbria (England). 2. Conodonts -

England, Northern. 3. Paleontology - Carboniferous.

4. Paleontology - Cumbria. 5. Paleontology -

England, Northern. I. Royal Ontario Museum.

1I. Title. III. Series.

QE899.2.C65P87 $1992 \quad 562.2094278 \quad$ C92-095152-X

ROYAL ONTARIO MUSEUM PUBLICATIONS IN LIFE SCIENCES

The Royal Ontario Museum publishes books on a variety of topics in the life sciences, including Life Sciences Contributions, a numbered series of original scientific publications. All manuscripts considered for publication are subject to the scrutiny and editorial policies of the Life Sciences Editorial Board, and to independent refereeing by two or more persons, other than Museum staff, who are authorities in the particular field involved.

Life Sciences Editorial Board

Senior Editor: J. H. McAndrews

Editor: M. D. Engstrom

Editor: G. B. Wiggins

External Editor: C. S. Churcher

Manuscript Editor: M. D. Engstrom

Production Editor: K. Mototsune

Mark A. Purnell received his Ph.D. (Geology) from the University of Newcastle upon Tyne, U. K., and has been postdoctoral research fellow in the Department of Invertebrate Palaeontology, Royal Ontario Museum, and in the Department of Geology, University of Toronto. He is currently postdoctoral research fellow in the Department of Geology, the University of Leicester, U. K.

The Royal Ontario Museum is an agency of the Ontario Ministry of Culture and Communications.

Printed and bound in Canada 


\section{CONTENTS}

$\begin{array}{ll}\text { Abstract } & 1\end{array}$

Introduction 1

Geological Setting: the Northumberland Trough 1

Stratigraphic Framework 1

Conodont Fauna 3

Materials and Methods $\quad 4$

$\begin{array}{ll}\text { Systematic Palaeontology } & 6\end{array}$

$\begin{array}{ll}\text { Hindeodus Rexroad and Furnish, } 1964 & 6\end{array}$

Hindeodus crassidentatus (Branson and Mehl, 1934b)? 6

$\begin{array}{ll}\text { Cavusgnathus Harris and Hollingsworth, } 1933 & 7\end{array}$

$\begin{array}{ll}\text { Cavusgnathus hudsoni (Metcalfe, 1981) } & 7\end{array}$

$\begin{array}{ll}\text { Cavusgnathus unicornis Youngquist and Miller, } 1949 & 10\end{array}$

Cavusgnathus cf. hudsoni (Metcalfe, 1981) 11

Cavusgnathus cf. unicornis Youngquist and Miller, 1949

$\begin{array}{ll}\text { Cavusgnathus? sp. a } & 12\end{array}$

Clydagnathus Rhodes, Austin, and Druce, $1969 \quad 12$

$\begin{array}{ll}\text { Clydagnathus windsorensis (Globensky, 1967) } & 13\end{array}$

Patrognathus Rhodes, Austin, and Druce, $1969 \quad 14$

Patrognathus capricornis (Druce, 1970) 15

$\begin{array}{ll}\text { Taphrognathus Branson and Mehl, 1941 } & 17\end{array}$

$\begin{array}{ll}\text { Taphrognathus carinatus (Higgins and Varker, 1982) } & 19\end{array}$

$\begin{array}{ll}\text { Taphrognathus varians Branson and Mehl, } 1941 & 20\end{array}$

$\begin{array}{ll}\text { Taphrognathus cf. varians } & 27\end{array}$

$\begin{array}{ll}\text { Taphrognathus sp. a } & 28\end{array}$

Taphrognathus? transatlanticus (von Bitter and Austin, 1984)? 30

Gnathodus Pander, $1856 \quad 30$

Gnathodus cuneiformis Mehl and Thomas, $1947 \quad 30$

Gnathodus? simplicatus (Rhodes, Austin, and Druce, 1969) 31

Mestognathus Bischoff, 1957

Mestognathus beckmanni Bischoff, 1957

Mestognathus praebeckmanni Sandberg, Johnston, Orchard, and von Bitter, 198633

Mestognathus praebeckmanni-M. beckmanni intermediates 33 
Polygnathus Hinde, 1879

Polygnathus bischoffi Rhodes, Austin, and Druce, 1969

Polygnathus mehli Thompson, 1967

Lochriea Scott, $1942 \quad 36$

$\begin{array}{ll}\text { Lochriea scotiaensis (Globensky, 1967) } & 36\end{array}$

$\begin{array}{ll}\text { Lochriea sp. indet. } & 37\end{array}$

$\begin{array}{ll}\text { Vogelgnathus Norby and Rexroad, } 1985 & 37\end{array}$

Vogelgnathus gladiolus Purnell and von Bitter, $1992 \quad 37$

Vogelgnathus kyphus Purnell and von Bitter, $1992 \quad 38$

Vogelgnathus pesaquidi Purnell and von Bitter, $1992 \quad 38$

$\begin{array}{ll}\text { Vogelgnathus cf. pesaquidi } & 38\end{array}$

Kladognathus Rexroad, 1958

Kladognathus tenuis (Branson and Mehl, 1941a) 39

"Apatognathus" 40

"Apatognathus" cuspidatus Varker, 1967

"Apatognathus" sp. a $\quad 42$

"Apatognathus" sp. indet. $\quad 42$

Genus Indeterminate $\quad 42$

$\begin{array}{ll}\text { Gen. a sp. a } & 42\end{array}$

$\begin{array}{ll}\text { Acknowledgments } & 43\end{array}$

Appendices 44

Appendix I: Locality Details $\quad 44$

Appendix II: Conodont Elements Recovered 46

Literature Cited $\quad 56$

$\begin{array}{ll}\text { Plates } & 63\end{array}$ 


\title{
Conodonts of the Lower Border Group and Equivalent Strata (Lower Carboniferous) in Northern Cumbria and the Scottish Borders, U.K.
}

\begin{abstract}
The shallow-shelf carbonates of the Lower Border Group and equivalent strata of the Northumberland trough have yielded conodont elements belonging to 28 multielement species. Study of these cavusgnathid-dominated faunas highlights the nced for major revision of the Cavusgnathidae. Cloghergnathus globenskii Austin is an ecophenotype of Taphrognathus varians Branson and Mchl; Cloghergnathus Austin is a junior synonym of Taphrognathus Branson and Mehl. Capricornognathus Austin appears to be a junior synonym of Patrognathus Rhodes, Austin, and Drucc.

The apparatuses of Cavusgnathus hudsoni (Metcalfe), Taphrognathus varians, Polygnathus mehli Thompson, and "Apatognathus" cuspidatus Varker are described for the first time. Patrognathus capricornis (Drucc), Mestognathus beckmanni Bischoff, Polygnathus bischoffi Rhodes, Austin, and Druce, and "Apatognathus" sp. a are partially reconstructed. The assignment of $C$. hudsoni to Cavusgnathus extends the range of the genus into the Tournaisian Series in Britain.
\end{abstract}

\section{Introduction}

\section{GEOLOGICAL SETTING: THE NORTHUMBERLAND TROUGH}

During the late Paleozoic, crustal extension associated with subduction-collision processes led to the formation of a number of sedimentary basins in what is now northern Britain (Johnson, 1981; Bott, 1987; Leeder, 1988; cf. Haszeldine, 1984, 1988). The Northumberland trough, comprising the Northumberland and Solway basins (Leeder, 1971, 1974a), developed during the Carboniferous as a half-graben structure between the Southern Uplands to the north and the Alston block to the south (Text-Fig. 1). Rapid, fault-controlled subsidence of the Northumberland trough took place during the early Dinantian (Johnson, 1984; Kimbell et al., 1989). At that time, the emergent margins of the trough were sources of clastic sediment (Leeder, 1974b). Marginal clastic deposition persisted in the Solway basin (Ord, Clemmey, and Leeder, 1988), but in the Northumberland basin axial drainage systems were dominant for most of the Dinantian. These drainage systems were sourced in the north and east (Robson, 1956;
Frost, 1969; Leeder, 1974b) and flowed towards the shallow, gulflike sea in the west. Marine influence in the trough, therefore, decreased eastwards (Garwood, 1931; Day, 1970; Johnson, 1984) and marine strata have not been recorded east or north of the Rothbury area (TextFig. 2).

The character of Dinantian sediments in the trough reflects the interplay of fluviodeltaic and shallow marine depositional systems (Leeder, 1974a, b, 1975a, b; Johnson, 1984). Sedimentation kept pace with subsidence (Johnson, 1984), and water depth in the trough probably never exceeded $50 \mathrm{~m}$ (Leeder and McMahon, 1988).

\section{STRATIGRAPHIC FRAMEWORK}

The outcrop of the Cementstone Group and Lower Border Group in the Northumberland basin, and the equivalent strata in the Solway basin is shown in Text-Fig. 2. With the exception of coastal sections on the Solway Firth, exposure is limited to isolated stream sections and rare 
quarries. There is considerable variation in the sediment characteristics and in the lithostratigraphic terminology applied to these strata in different areas of the Northumberland trough. Throughout this work the following stratigraphic schemes are followed: Fowler $(1936,1966)$ for sections located in the Rothbury and North Tyne areas; Leeder (1974b) for the Newcastleton-Langholm area; Day (1970) for the Bewcastle area; Craig (1956) for the Kirkbean outlier; Deegan (1973) and Ord, Clemmey, and Leeder (1988) for the Rerrick outlier (see Text-Fig. 2 for locations). Where appropriate, lithostratigraphic terms are modified according to Holland et al. (1978), although the term "band" is replaced by "Member." Biostratigraphic terminology also follows Holland et al. (1978). Locality details are included as Appendix I. Stratigraphic relationships between Lower Border Group sections and equivalent strata within the Northumberland trough are shown in Text-Fig. 3.

The Cementstone Group in the Rothbury area comprises a generally thinly-bedded sequence of alternating sandstones, shales, and lime mudstones (Fowler, 1936). The lime mudstones are commonly sandy or dolomitic (Fowler, 1936), and the limestone members towards the top of the group are dominated by calcareous algae, chiefly in the form of oncoids. Deposition of these sediments took place in a shallow, restricted intertidal setting or a coastal plain environment with periodic marine infiuence (Belt, Freshney, and Read, 1967). The algal members were deposited in a shallow, restricted shelf/ lagoon environment.

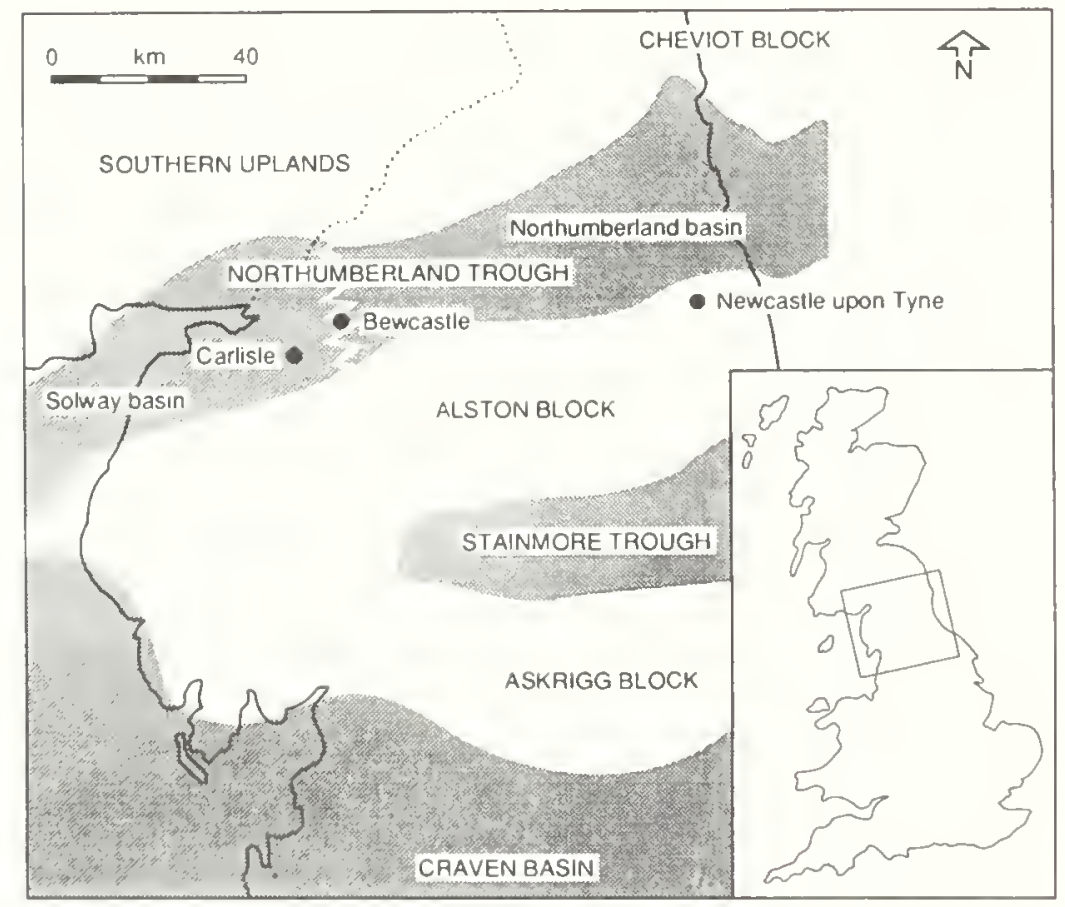

TEXT-FIG. 1. Location and palaeogeographic setting of the Northumberland trough.
In the "North Tyne basin" (Fowler, 1966), the Cementstone Group is probably not more than $180 \mathrm{~m}$ thick (Fowler, 1966) and consists of sandstones, shales, and limestones. Some of the limestones contain marine faunal components such as crinoid ossicles and brachiopods (Fowler, 1966; pers. obs.). The character of the sequence reflects the interaction of fluviodeltaic and marine depositional systems (cf. Fowler, 1966).

The sediments of the Lower Border Group in the Bewcastle area were deposited in a variety of environments reflecting periodic delta progradation into a shallow marine gulf (Leeder, 1974b, 1975a, b). Leeder (1974b) discussed the detailed sedimentology of the clastic deltaic facies. Carbonate depositional environments ranged from intertidal to shallow subtidal marine (see Leeder, 1975a, b).

In the Newcastleton-Langholm area, the Whita Formation is more than $500 \mathrm{~m}$ thick near Langholm and is composed mainly of sandstones deposited in a fluvial environment (Leeder, 1974b). The Black Burn Formation comprises more than $150 \mathrm{~m}$ of sandstones, shales, and limestones deposited in coastal plain, marginal marine, and deltaic environments (Leeder, 1974b). The Arnton Fell Formation is more than $200 \mathrm{~m}$ thick and is made up of sandstones and shales with rare thin beds of limestone. The sequence reflects deposition in a fluvial setting with ephemeral lake development (Leeder, 1974b). A section exposed in Black Burn (G.R. NY 47878880 to 48768869; section 11 of Leeder, 1972, 1974b; locality 18 on Text-Fig. 2) was considered to be part of the Arnton Fell Formation by Leeder (1972). This section was included in the formation in figure 1 of Leeder (1974b) but not in the details of sections (1974b:175); its stratigraphic position is uncertain. More than $250 \mathrm{~m}$ of alternating beds of sandstone, shale, and limestone make up the Liddel Formation. Clastic strata were deposited in deltaic environments (Leeder, 1974b); carbonate beds in a range of shallow subtidal and probable intertidal marine environments (Leeder, 1975a, b). The Harden Member is distinguished by its distinctive fauna, which includes abundant Syringothyris cf. cuspidata (J. Sowerby) (Lumsden et al., 1967). It was deposited in a shallow subtidal marine environment.

The Basal Cementstone Formation of the Cementstone Group in the Kirkbean outlier is composed of shales and lime mudstones. Some of the latter are dolomitic and occasionally contain ostracodes, bivalves, or vermiform gastropods (Craig, 1956; Leeder, 1974b; pers. obs.). Deposition probably took place in a shallow, very restricted marine or coastal plain environment, similar to that discussed by Belt et al. (1967). The Southerness Formation comprises approximately $140 \mathrm{~m}$ of altemating shales and fossiliferous limestones, containing a fauna dominated by brachiopods and molluscs (Craig, 1956; 


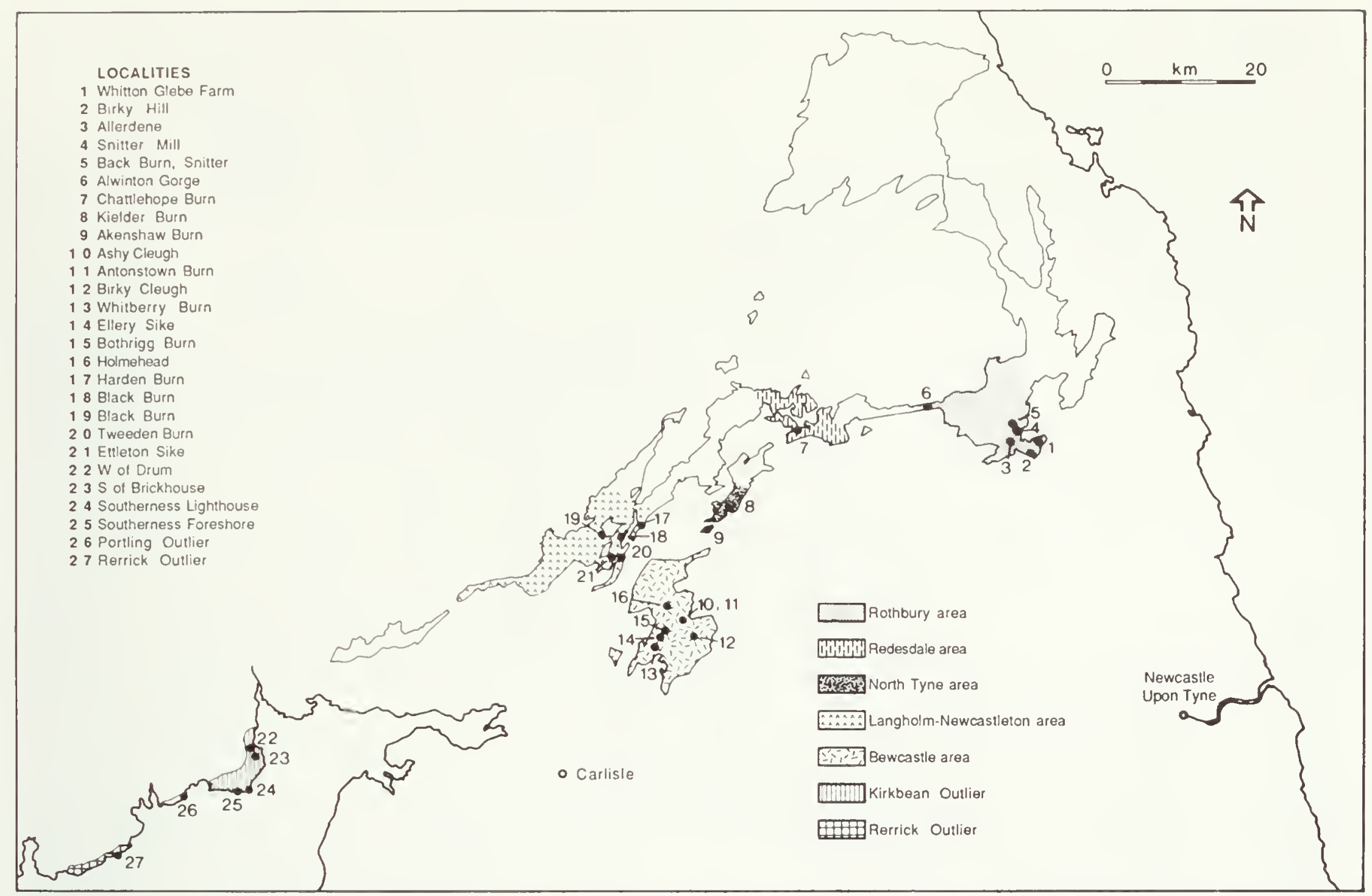

TEXT-FIG. 2. Outcrop of the Lower Border and Cementstone groups in the Northumberland basin, and equivalent strata in the Solway basin, showing localities and geographic subdivisions used in the text. For locality details see Appendix I.

pers. obs.). These strata were probably deposited in a shallow open marine or slightly restricted subtidal environment. The Gillfoot Formation is dominantly composed of reddish-brown conglomerates and sandstones (Craig, 1956). Occasional thin limestones and some of the sandstone beds contain a fauna that includes brachiopods and corals (Craig, 1956; pers. obs.). The depositional environment was, therefore, at least periodically marine.

In the Rerrick outlier, the Wall Hill Sandstone and Orroland groups together represent the approximate lateral equivalents of the Lower Border Group (Deegan, 1973). The Wall Hill Sandstone Group is $360 \mathrm{~m}$ thick and comprises the White Port, Sheep Bught, and Abbey Head formations, each composed of different proportions of conglomerates, sandstones, siltstones, and shales (Deegan, 1973). These strata were deposited in a variety of fluvial environments (Deegan, 1973) and have not been sampled for conodonts. Strata of the Orroland Group reflect deposition under a range of dominantly fluvial and alluvial conditions. Of the seven formations of the group (see Deegan, 1973), only the Barlacco Heugh and Orroland Lodge formations contain marginal marine strata.

\section{CONODONT FAUNA}

Previous work on British Dinantian conodonts was reviewed by Varker and Sevastopulo (1985). Few studies have dealt with shallow-shelf conodont faunas of Dinantian age; Rhodes, Austin, and Druce (1969) is the most recent major systematic work to do so. Since that publication, there has been a major shift away from traditional "form taxonomy" towards a more biologically sound, multielement concept of conodont species. The systematic palaeontology of shallow-shelf faunas is, therefore, in need of thorough revision.

Conodont faunas from shallow restricted environments are usually limited in their diversity (e.g., von Bitter and Plint-Geberl, 1982; Higgins and Varker, 1982; Austin and Davies, 1984). This may limit their biostratigraphic utility, but such faunas provide good evidence for the multielement composition of conodont species (von Bitter, 1976; Kozur, 1976). Study of the low-diversity faunas recovered from restricted facies of the Northumberland trough sequence has enabled reconstruction of the apparatuses of several species of conodonts. 


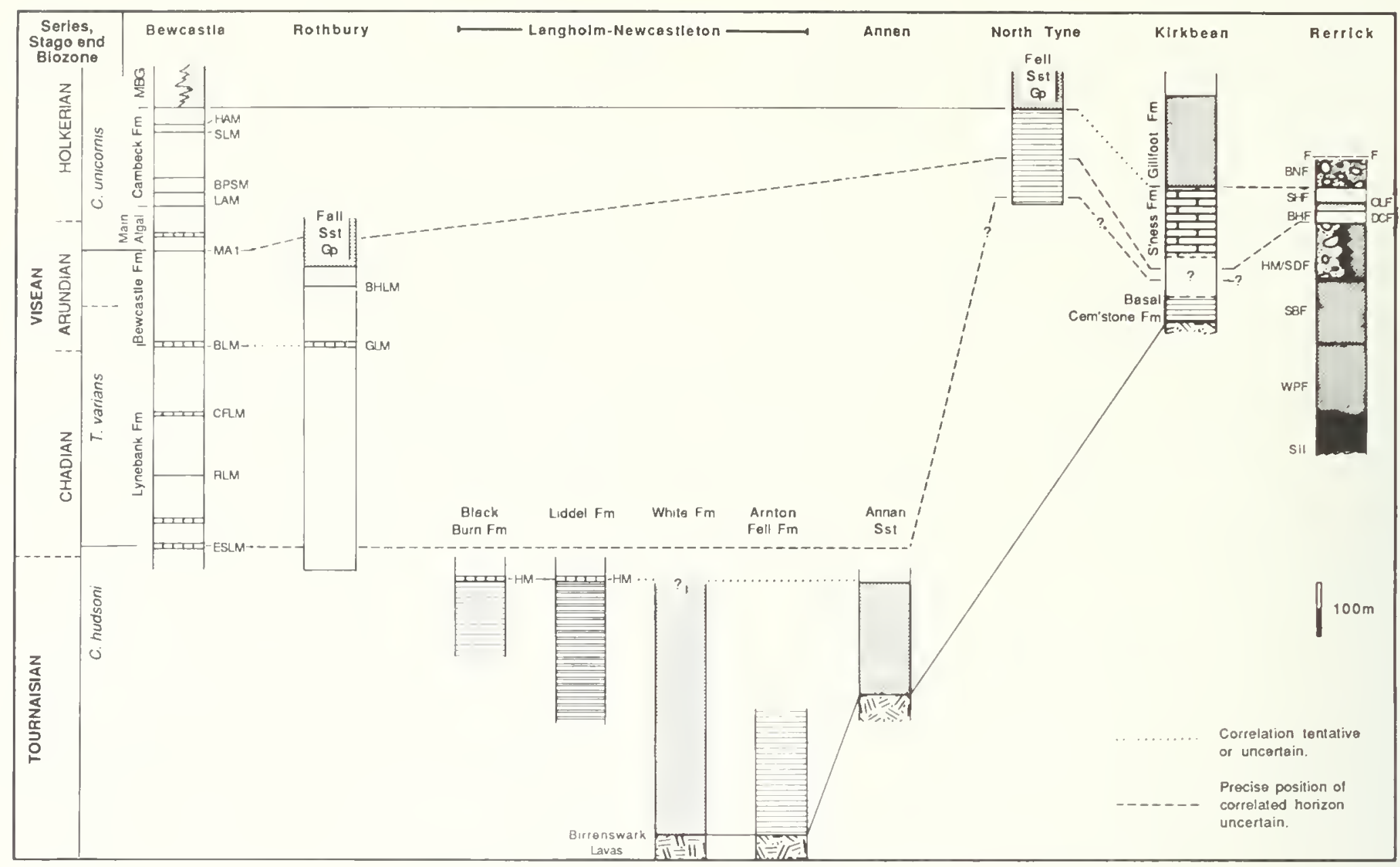

TEXT-FIG. 3. Stratigraphic framework of the Lower Border and Cementstone groups and equivalent strata in the Northumberland trough. Conodont biozonation and correlation from Purnell (1989); local correlation in the Langholm-Newcastleton area follows Leeder (1974b). Sections are not arranged geographically. MBG = Middle Border Group; ESLM = Ellery Sike Limestone Member; RLM = Rawney Limestone Member; CFLM = Common Flat Limestone Member; BLM = Bogside Limestone Member; MA 1 = Main Algal Member One; LAM = Lower Antiquatonia Member; BPSM = Barron's Pike Sandstone Member; SLM = Syringothyris Limestone Member; HAM = Hillend Algal Member; GLM = Glebe Limestone Member; BHLM = Birky Hill Limestone Member; HM = Harden Member; WPF = White Port Formation; SBF = Sheep Bught Formation; HM/SDF = Hanged Man and Spouty Dennans formations; DCF = Dropping Craig Formation; BHF = Barlacco Heugh Formation; OLF = Orroland Lodge Formation; SHF = Scar Heugh Formation; BNF = Black Neuk Formation.

\section{Materials and Methods}

One hundred and ninety-five samples from the Lower Border Group and equivalent strata were processed for conodonts using standard recovery techniques (Austin, 1987). Most samples were taken from the Lower Border Group in its type area (Text-Fig. 4). Samples were selected to maximize yield and stratigraphic coverage, but also to represent the broad range of carbonate facies encountered. Almost 5000 conodont elements were recovered, most of which were assigned to one of 28 species of 12 genera.

With a few exceptions, the suprageneric classification of Sweet (1988) is followed herein. The Conodonta, however, are referred to the phylum Chordata (Aldridge et al., 1986; see Smith, 1990, for discussion).

Wherever possible, synonymy lists are abbreviated to give the original species designation, important taxonomic changes, and the most recent reference containing a more complete list. All synonymy lists are annotated using the symbols recommended by Matthews (1973, after Richter, 1948; Rabien, 1954). To avoid confusion, these symbols are enclosed in square brackets and appear to the left of taxonomic names.

Element notation and, except where indicated otherwise, morphological terminology follows Sweet (1981a, b); symmetry classification follows Lane (1968); and heterochronic terminology follows Alberch et al. (1979). Open nomenclature and the signs for taxonomic uncertainty follow Bengtson (1988). The use of quotation marks to indicate invalid or obsolete taxonomic names follows Jcppsson and Merrill (1982). The terms dextral and sinistral are used to describe curvature of elements (contra Sweet, 1981b:W63, W67). In upper view, dextral elements are convex towards the right, sinistral elements 
are convex towards the left. Under "Material Studied" (and in Appendix II), numbers in parentheses refer to additional, poorly preserved, usually fragmentary specimens and to questionably assigned specimens. All figured material is deposited in the Department of Invertebrate Palacontology, Royal Ontario Museum.

TEXT-FIG. 4. Generalized vertical section through the Lower Border Group in the Bewcastle area showing sample distribution and lithostratigraphic terminology (based on Day, 1970; and measured sections of the author). For locality details see Appendix I.

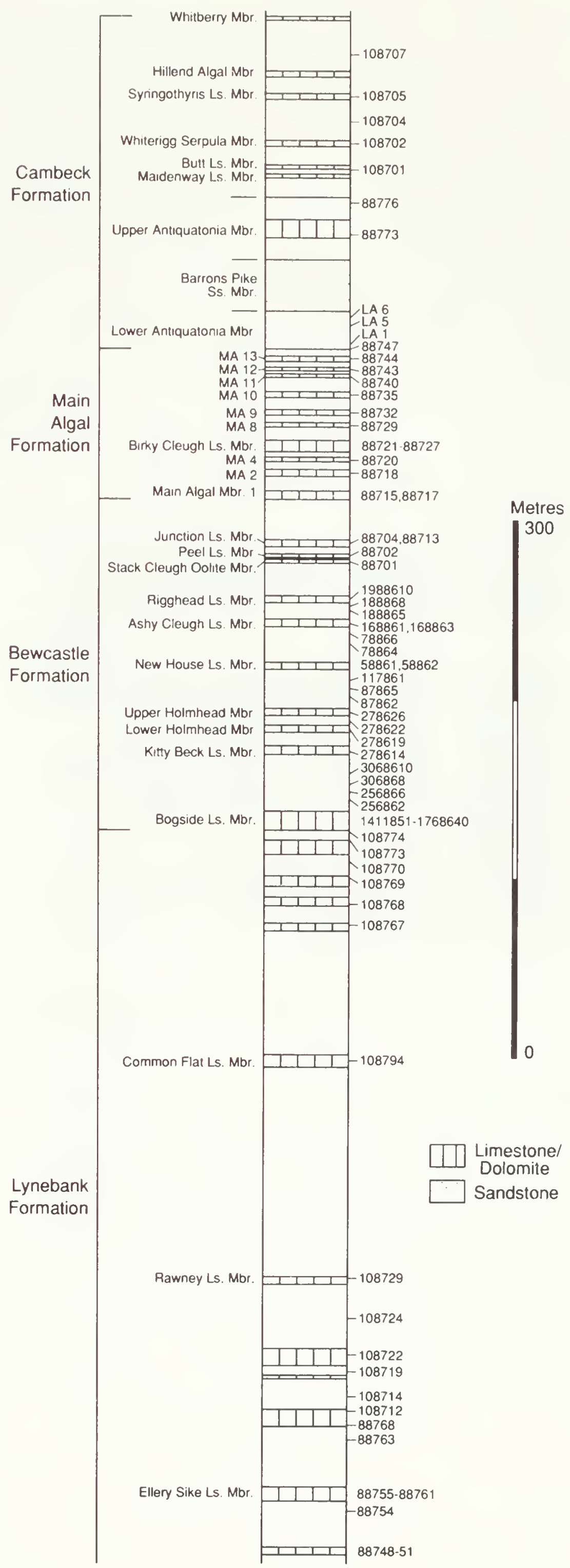




\title{
Systematic Palaeontology
}

\author{
Phylum Chordata Bateson, 1886 \\ Class Conodonta Pander, 1856 \\ Subclass Conodonti Branson, 1938 \\ Order Ozarkodinida Dzik, 1976 \\ Family Anchignathodontidae Clark, 1972
}

\section{Genus Hindeodus Rexroad and Furnish, 1964}

Hindeodus Rexroad and Furnish, 1964:671.

Anchignathodus Sweet, 1970:7.

\section{DIAGNOSIS}

See Sweet (in Ziegler, 1977:203-4).

\section{TYPE SPECIES}

Trichonodella imperfecta Rexroad, 1957, by original designation (= Sa element of Hindeodus cristula (Youngquist and Miller, 1949)).

Hindeodus crassidentatus (Branson and Mehl, 1934b)? Plate 1, Figs. 1a, b

Bispathodus stabilis (Branson and Mehl)-Armstrong and Purnell, 1987, pl. 1, fig. 5.

\section{MATERIAL STUDIED}

Pa elements, 3(4) from the Cambeck and Bewcastle formations, Lower Border Group, and the Southerness Formation, Cementstone Group.

\section{DESCRIPTION}

Apparatus unknown. See Branson and Mehl (1934b:276) under Spathodus crassidentatus for a description of $\mathrm{Pa}$ elements.

\section{DISCUSSION}

These specimens are indistinguishable from "Spathognathodus crassidentatus" sensu Klapper (1966), assigned by Sweet (1988) to Hindeodus. Their occurrence in rocks of Chadian and Arundian age is considerably above the range indicated for the species by Klapper (1966) and by Rexroad and Thompson (1979). This apparent anomaly suggests that the range of the species is greater than previously thought, or that these specimens are reworked. Alternatively, they may represent a younger homeomorph of $H$. crassidentatus. Considering their simple carminate morphology, the latter possibility is the most likely. Without additional information, such as ontogeny or apparatus structure, the assignment of these and similar specimens remains problematical (see Rexroad and Thompson, 1979; discussion of Gen. a sp. a).

Family Cavusgnathidae Austin and Rhodes, in Robison, 1981

\section{DISCUSSION}

The family Cavusgnathidae as defined by Austin and Rhodes (in Robison, 1981) contains seven genera. Of these, Capricornognathus Austin (in Austin and Mitchell, 1975) and Cloghergnathus Austin (in Austin and Mitchell, 1975) are herein considered junior synonyms of Patrognathus Rhodes, Austin, and Druce, 1969, and of Taphrognathus Branson and Mehl, 1941, respectively.

The apparatuses of the remaining five genera are, as far as they are known, similar, and the genera are differentiated on $\mathrm{Pa}$ element morphology (Table 1). Considering the similarities between these genera and the rather minor differences that divide them, compared with their intra- and interspecific variability, the separate generic status of each is perhaps unjustified (cf. Sweet, 1988). A major revision of the systematics of the Cavusgnathidae based on apparatus structure and phylogenetic information is required but is beyond the scope of this study. 
TABLE 1. Pa element characteristics important in differentiating genera of Cavusgnathidae.

\begin{tabular}{lllll}
\hline $\begin{array}{l}\text { Cavusgnathus } \\
\text { Harris and } \\
\text { Hollingsworth } 1933\end{array}$ & $\begin{array}{l}\text { Taphrognathus } \\
\text { Branson and Mchl } \\
1941 \mathrm{c}\end{array}$ & $\begin{array}{l}\text { Adetognathus } \\
\text { Lane 1967 }\end{array}$ & $\begin{array}{l}\text { Clydagnathus } \\
\text { Rhodes, Austin, } \\
\text { and Druce 1969 }\end{array}$ & $\begin{array}{l}\text { Patrognathus } \\
\text { Rhodes, Austin, } \\
\text { and Druce 1969 }\end{array}$ \\
\hline $\begin{array}{l}\text { Right lateral } \\
\text { anterior blade }\end{array}$ & $\begin{array}{l}\text { Right, left, or } \\
\text { medial anterior } \\
\text { blade }\end{array}$ & $\begin{array}{l}\text { Right or left } \\
\text { lateral anterior } \\
\text { blade }\end{array}$ & $\begin{array}{l}\text { Right lateral } \\
\text { anterior blade }\end{array}$ & $\begin{array}{l}\text { Medial anterior } \\
\text { blade }\end{array}$ \\
$\begin{array}{l}\text { Ridged platform } \\
\text { omament }\end{array}$ & $\begin{array}{l}\text { Nodose, ridged, or } \\
\text { smooth platform } \\
\text { omament }\end{array}$ & $\begin{array}{l}\text { Ridged platform } \\
\text { omament }\end{array}$ & $\begin{array}{l}\text { Discrete nodose } \\
\text { platform ornament }\end{array}$ & $\begin{array}{l}\text { Nodose and/or } \\
\text { ridged platform } \\
\text { omament }\end{array}$ \\
$\begin{array}{l}\text { Class IIIa } \\
\text { symmetry }\end{array}$ & $\begin{array}{l}\text { Class II or III } \\
\text { symmetry }\end{array}$ & $\begin{array}{l}\text { Class II or IIIb } \\
\text { symmetry }\end{array}$ & $\begin{array}{l}\text { Class IIIa } \\
\text { symmetry }\end{array}$ & $\begin{array}{l}\text { Class IIIa } \\
\text { symmetry }\end{array}$ \\
$\begin{array}{l}\text { Blade profile } \\
\text { variable }\end{array}$ & $\begin{array}{l}\text { Blade profile } \\
\text { variable }\end{array}$ & $\begin{array}{l}\text { Blade profile } \\
\text { variable }\end{array}$ & $\begin{array}{l}\text { Blade usually } \\
\text { highest } \\
\text { posteriorly }\end{array}$ & $\begin{array}{l}\text { Blade highest } \\
\text { posteriorly }\end{array}$ \\
& & & & \\
\hline
\end{tabular}

\section{Genus Cavusgnathus Harris and Hollingsworth, 1933}

Cavusgnathus Harris and Hollingsworth, 1933:200.

Lewistownella Scott, 1942:299.

Windsorgnathus Austin, in Austin and Mitchell, 1975:53.

\section{REVISED DIAGNOSIS}

Apparatus seximembrate when fully developed: $\mathrm{Pa}$ elements carminiscaphate to anguliscaphate with conspicuous central trough; anterior blade attached to right side of platform; parapets transversely ridged; basal cavity bilaterally subsymmetrical to asymmetrically flared. $\mathrm{Pb}$ elements angulate; $\mathrm{M}$ elements dolabrate; Sa element alate; $\mathrm{Sb}$ and Sc elements bipennate. Pa elements paired with Class IIIa symmetry; all other elements, apart from the Sa, symmetrically paired.

\section{TYPE SPECIES}

Cavusgnathus alta Harris and Hollingsworth, 1933, by original designation.

\section{DISCUSSION}

This concept of Cavusgnathus is essentiaily the same as that of Norby (1976) and Rexroad (1981). Nonplatform elements of various Cavusgnathus species are similar, and generally they can be specifically assigned only in samples that contain $\mathrm{Pa}$ elements of just one Cavusgnathus species.

\section{Cavusgnathus hudsoni (Metcalfe, 1981)}

Plate 1, Figs. 2-14

[v.] Cavusgnathus charactus Rexroad-Rhodes, Austin, and Druce, 1969:79-80, pl. 13, figs. 6, 7, 13 [Pa elements]. [v.] Taphrognalhus varians Branson and Mehl-Rhodes, Austin, and Druce, 1969:241, 242, pl. 13, figs. 4, 5 [Pa elements].

Cavusgnathus unicornis? Youngquist and Miller-Druce, 1969:48, 49, pl. 3, figs. 1, 2 [Pa elements].

[v.] Taphrognathus varians-Austin, 1973, figs. 1.20, 1.21 [cop. Rhodes, Austin, and Druce, 1969, pl. 13, figs. 4a, 6a] [Pa elements].

[v.] Windsorgnathus windsorensis (Globensky)-Austin in Austin and Mitchell, 1975:53, pl. 1, figs. 20, 23, 25 [Pa elements].

[v.] Hibbardella parva Rhodes, Austin, and Druce-Austin in Austin and Mitchell, 1975:45, table 2 [Sa element] [not figured].

[non] Clydagnathus? hudsoni Metcalfe, 1980:176, pl. 13, figs. 8, 9.

[v*] Clydagnathus? hudsoni Metcalfe, 1981:19, pl. 1, fig. 5 [Pa element].

[v.] Taphrognathus varians-Austin and Rhodes in Robison, 1981, fig. 108,1 [cop. Rhodes, Austin, and Druce, 1969, pl. 13, figs. 5a-c] [Pa element].

Taphrognathus sp. Austin and Davies, 1984, pl. 2, figs. 2, 3, 9 [Pa elements].

Cloghergnathus sp. Austin and Davies, 1984, pl. 2, figs. 4, 6, 27 [Pa elements].

Cavusgnathus sp. Austin and Davies, 1984, pl. 2, figs. 5, 7 , 8 [Pa elements].

[(?)] Cavusgnathus unicornis-Austin and Davies, 1984, pl. 2, figs. 25, 26 [Pa elements].

[v.] Cavusgnathus charactus-Varker and Sevastopulo, 1985, pl. 5.6, figs. 14, 15 [cop. Rhodes, Austin, and Druce, 1969, pl. 13, figs. 7c, 7a] [Pa element]. 


\section{REVISED DIAGNOSIS}

$\mathrm{Pa}$ element diagnostic: anterior blade higher than long, fixed for up to approximately half its length, higher than parapets; central trough may be closed by the anterior end of the left parapet; parapets convex upwards; basal cavity bears a medial groove for its entire length.

\section{HOLOTYPE}

British Geological Survey, MPK 1907 (Metcalfe, 1981, pl. 1, fig. 5).

\section{TYPE HORIZON AND LOCALITY}

Haw Bank Limestone sample 272 of Metcalfe (1981), Haw Bank Quarry, North Yorkshire, U.K. (G.R. SE 015532).

\section{MATERIAL STUDIED}

Pa elements, $259(65)$ [ $\alpha$ blade, $47(1) ; \beta$ blade $65 ; \gamma$ blade 12 ; intermediate blade 107; indeterminable blade morphology 28(64). $192 \mathrm{~Pa}$ elements complete enough for curvature determination: 104 sinistral, 68 dextral, and 20 straight]. $\mathrm{Pb}$ elements, 47(15); $\mathrm{M}$ elements, 23(1); Sa elements, 6(2); Sb elements, 3; Sc elements, 5(1). All material from the Liddel and Lynebank Formations, Lower Border Group.

\section{DESCRIPTION}

Pa elements. The anterior blade is between one-quarter and two-fifths of total element length. It is composed of three to five, rarely six, laterally compressed denticles, fused apart from their tips, and is always developed on the right side of the element. A notch is commonly developed between the blade and the right parapet, occasionally with some medial displacement of the blade. The shape of the blade in lateral view is comparable to that of $C$. unicornis sensu $\operatorname{Rexroad}(1981)$ and may be of $\alpha, \beta, \gamma$, or intermediate form (see Text-Fig. 5). $\alpha-\beta$ intermediate blades are particularly common, denticles increasing in size and height posteriorly, but lacking a conspicuously larger posterior denticle. The posteriormost blade denticle is often reclined and is always higher than the anterior end of the right parapet. Blade height is greater than or equal to length; the fixed blade is usually between one-fifth and one-half of total blade length but may be slightly more or less.

The platform height is greater than or, less commonly, equal to width, decreasing slightly in the posterior half. The platform may be straight but usually exhibits some lateral curvature with the outer margin convex and the inner margin convex, straight, or concave. In some specimens, the interplay of arching and lateral curvature give a twisted appearance to the posterior end of the platform. The length of the platform, measured from the anterior end of the left parapet to the posterior tip, is

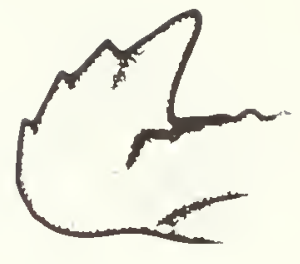

\section{$\alpha$}
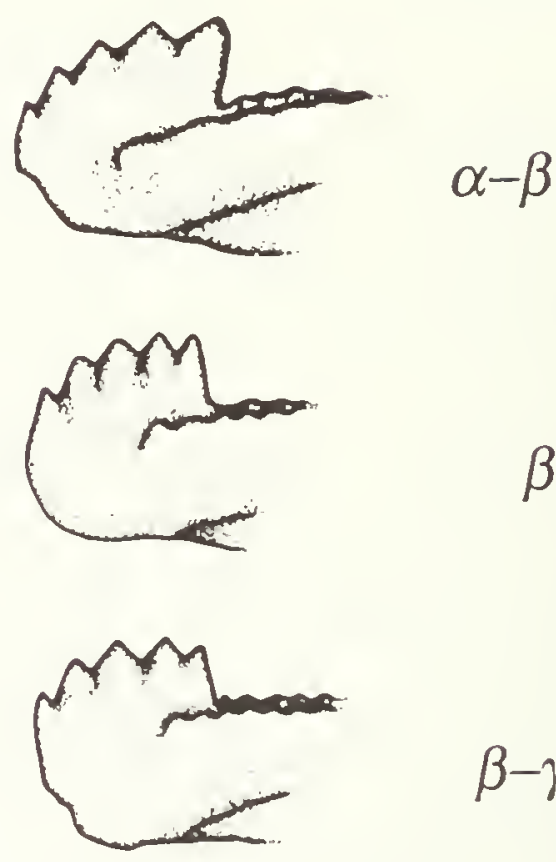

$\beta-\gamma$

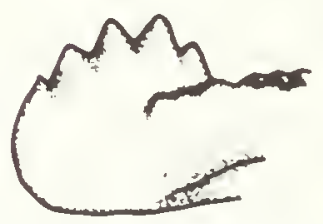

$\gamma$

TEXT-FIG. 5. Blade form in Cavusgnathus hudsoni. Blade type indicated by Greek letters.

generally between four and six times the width, occasionally as much as seven times or as litule as three times. Maximum platform width is attained either around midlength, gradually tapering to the posterior, or in the posterior third, tapering more rapidly. The parapets are ornamented by weak transverse ridges which may be more strongly developed in larger specimens. The ridges extend up to the parapet crests and create a serrated profile, the strength of which depends on the development of the ridges. The medial trough becomes shallower anteriorly and posteriorly according to the downward curvature of the parapets. In most specimens, the trough remains open at the anterior end but the left parapet may converge with the blade to more or less close the gap. Two or three nodes may be present in the posterior part of the trough forming a short carina of variable strength. The posterior tip of the platform is generally sharply pointed and the carina, if present, may extend posteriorly as a short blade. The lower profile of the platform in lateral view is concave, generally not strongly so, but this is more evident when viewed from the right. In some specimens, the lower margin of the blade is slightly upturned relative to the platform. 
The basal cavity is lanceolate, tapering anteriorly and posteriorly. It is widest and decpest just anterior of element midlength and comes to a point at, or very close to, the posterior tip of the element. A medial groove is present along the entire length of the cavity; on either side of this groove, both sides of the cavity extend an approximately equal distance anteriorly. The generally slight asymmetry of the cavity increases in some larger specimens with greater lateral flaring.

Pb elements. See Rexroad (1957:36) under Ozarkodina compressa. These elements are variable; some specimens (c.g., PI. 1, Fig. 10) have a relatively large basal cavity, widest beneath the cusp, and a strongly reclined cusp and denticles. Such specimens approach the morphology of "Subbryantodus stipans" sensu Rexroad (1957). Norby (1976) noted the similarity between "S. stipans" and the $\mathrm{Pb}$ elements of Cavusgnathus. Stratigraphically younger specimens are like "O. compressa" but tend to have more discrete, elongate denticles and cusp.

M elements. See Rexroad (1957:34) under Neoprioniodus loxus. Some M elements of $C$. hudsoni (e.g., Pl. 1, Fig. 14) show less downward deflection of the posterior process than " $N$. loxus" and approach "Neoprioniodus varians (Branson and Mehl)" in form. The discreteness of major denticles and the development of minor denticles also vary.

Sa elements. See Rexroad (1958a:18) under Hibbardella ortha.

Sb elements. The anterior process is incomplete in all specimens but is at least as long as the posterior process. It is laterally compressed and bears five discrete thin denticles, subcircular in cross-section, with one or two minor denticles occasionally developed between them. The denticles are erect at the anterior end but are increasingly reclined towards the cusp. The cusp itself is reclined; it is slightly larger than the anterior process denticles but is otherwise similar. The posterior process is slightly higher and thicker and is deflected slightly downwards relative to the anterior. The denticulation is similar to that of the anterior process but the five major denticles increase in size, height, and reclination, posteriorly. The figured specimen (Pl. 1, Fig. 13) has two minor denticles on the posterobasal edge of the last major denticle. The lower edge has a sharp downward deflection at the posterior end of some specimens. The basal cavity is developed obliquely beneath the cusp, aligned with its long axis. It is narrow, shallow and elongate, rather conical in one small specimen, and tapers anteriorly and posteriorly. The cavity does not appear to continue as a groove along the process, but a thin zone of recessive basal margin is developed along the lower edge of the posterior process.

Sc elements. See Hass (1953:81) under Hindeodella ensis and Clarke (1960:8) under H. tenuis.

\section{DISCUSSION}

The Pa elements of $C$. hudsoni exhibit considerable variation in many aspects of their morphology. Individual characters vary continuously and in discord with other characters; no consistently recognizable relationship between different characters has been observed. The arbitrary choice of a single character to subdivide this plexus into a number of more convenient "species" would be a backward step taxonomically. Rather, these variable elements are interpreted as members of a single species with considerable plasticity in $\mathrm{Pa}$ element development.

Clydagnathus? hudsoni Metcalfe, 1981, falls comfortably within the range of variation described above. The original concept of the species (Metcalfe, 1981) was more restricted, almost certainly due to the small sample size of $10 \mathrm{~Pa}$ elements. The assignment to Clydagnathus? based on anterior closure of the trough has been emended: firstly because of the variability of the character, and secondly because anterior trough closure is no longer considered diagnostic of Clydagnalhus (Nicoll and Druce, 1979; contra Rhodes, Austin, and Druce, 1969). The posterior blade denticle is broken in the holotype of Cavusgnathus hudsoni; originally the blade probably had an a $\alpha-\beta$ intermediate form.

The specimens from the Main Algal "series" (= Liddel Formation) of Harden Burn, Roxburghshire, figured by Rhodes, Austin, and Druce (1969) as Cavusgnathus charactus Rexroad and Taphrognathus varians Branson and Mehl, are referred to $C$. hudsoni. One of these specimens was subsequently figured as $T$. varians in the Treatise on Invertebrate Paleontology (Austin and Rhodes in Robison, 1981).

Nicoll and Druce (1979) included within their concept of Clydagnathus cavusformis specimens figured by Druce (1969) as Cavusgnathus? unicornis. These specimens appear to have ridged platform ornament rather than the nodose ornament characteristic of Clydagnathus and are herein considered to belong to $C$. hudsoni. Austin (in Austin and Mitchell, 1975) distinguished his new genus Windsorgnathus from Cavusgnathus on stratigraphic evidence alone. Austin and Rhodes (in Robison, 1981) placed Cavusgnathus and Windsorgnathus in synonymy. Windsorgnathus windsorensis sensu Austin (in Austin and Mitchell, 1975) is distinct from Clydagnathus windsorensis (Globensky) (von Bitter and Austin, 1984) and is identical to Cavusgnathus hudsoni from the Lynebank Formation of the Northumberland trough. $C$. hudsoni also occurs in Tournaisian strata of the Irish Republic, variously reported as species of Cavusgnathus, Clydagnathus, and Taphrognathus (Johnston, 1976; Marchant, 1978; Rees, 1987).

Variation in $C$. hudsoni Pa clements appears to have decreased through time. Specimens of upper Tournaisian age from Ireland, from the Craven basin (Metcalfe, 1981), 
TABLE 2. Distinguishing characteristics of Cavusgnathus charactus Rexroad, C. hudsoni (Metcalfe), and $C$. unicornis Youngquist and Miller. Characteristics of $C$. charactus based on Rexroad (1957); those of $C$. hudsoni on personal observation; those of $C$. unicornis on Youngquist and Miller (1949), Rexroad (1957), Rexroad (1981), and various published plates.

\begin{tabular}{lll}
\hline Cavusgnathus charactus & Cavusgnathus hudsoni & Cavusgnathus unicornis \\
\hline $\begin{array}{l}\text { "Attachment scar" anterior } \\
\text { of basal cavity }\end{array}$ & No "attachment scar" & No "attachment scar" \\
$6-8$ blade denticles & $3-5$ blade denticles & \\
Blade $<1 / 3$ free & Blade $>1 / 2$ free & $5-8$ blade denticles \\
$\begin{array}{l}\text { Blade slightly }>1 / 3 \\
\text { of element length }\end{array}$ & $\begin{array}{l}\text { Blade usually }<1 / 3 \text { of } \\
\text { element length }\end{array}$ & Blade $<1 / 2$ free \\
$\begin{array}{l}\text { Inner parapet nearly } \\
\text { straight, convex at tip }\end{array}$ & $\begin{array}{l}\text { Inner parapet convex, } \\
\text { straight, or concave }\end{array}$ & $\begin{array}{l}\text { Blade commonly }>1 / 3 \text { of } \\
\text { element length }\end{array}$ \\
$\begin{array}{l}\text { Trough always open } \\
\text { at anterior end }\end{array}$ & $\begin{array}{l}\text { Trough may be closed } \\
\text { at anterior end }\end{array}$ & $\begin{array}{l}\text { Both parapets convex } \\
\text { outwards }\end{array}$ \\
$\begin{array}{l}\text { Parapet notch } \\
\text { diagnostic }\end{array}$ & $\begin{array}{l}\text { Parapet notch } \\
\text { common }\end{array}$ & $\begin{array}{l}\text { Trough always open } \\
\text { at anterior end }\end{array}$ \\
Blade slightly convex & $\alpha, \beta, \gamma$, and intermediate \\
blade morphologies & Parapet notch \\
rare
\end{tabular}

and from the Liddel Formation (Rhodes, Austin, and Druce, 1969; Austin and Davies, 1984; this study) exhibit greater morphological plasticity than specimens of Chadian age from Northern Ireland (Austin in Austin and Mitchell, 1975), and from the Lynebank Formation (this study). This apparent trend may prove spurious given that, at present, many more specimens are known from Tournaisian strata.

In the Cavusgnathidae, genera and species within a genus are mainly distinguished on $\mathrm{Pa}$ element morphology. Although certain $\mathrm{Pa}$ element specimens within the range of variation of Cavusgnathus hudsoni approach the morphology of $C$. charactus and $C$. unicornis, they can be differentiated on the basis of the characters in Table 2 . Cavusgnathus altus differs in the shape and proportions of the irregular cockscomblike blade and in the termination of the basal cavity one-quarter to one-fifth of the platform length from the posterior end. The platform ornament, blade shape and proportions, and the strong downward deflection of the lower edge of the blade, only rarely developed in $C$. hudsoni, serve to distinguish $C$. naviculus.

An Sa element occurring with $C$. hudsoni in the Lower Carboniferous Shale of Northern Ireland was identified by Austin (in Austin and Mitchell, 1975) as Hibbardella parva. This element is very similar to the Sa element figured here (PI. 1, Fig. 11) and probably belongs to $C$. hudsoni. Sc elements of $C$. hudsoni show considerable variation, especially in the degree of inward and upward or downward curvature of the anterior process. One of the figured specimens (Pl. 1, Fig. 12) has very little inward curvature of the process and may be transitional to an $\mathrm{Sb}$ element. The other figured specimen (PI. 1, Fig. 9) shows the abrupt downward curvature of the lower edge developed at the posterior end of some specimens.

\section{Cavusgnathus unicornis Youngquist and Miller, 1949}

Plate 2, Figs. 1-5, 7

Cavusgnathus unicornis Youngquist and Miller, 1949:619, pl. 101, figs. 18-23 [Pa element, $\alpha$ morphotype].

Cavusgnathus regularis Youngquist and Miller, 1949:619, pl. 101, figs. 24, 25 [Pa element, $\beta$ morphotype].

[v*] Cavusgnathus convexa Rexroad, 1957:17, pl. 1, figs. 3-6

[Pa element, $\gamma$ morphotype].

Neoprioniodus loxus Rexroad, 1957:34, pl. 2, figs. 8, 9, 14

[M element]. 
Ozarkodina compressa Rexroad, 1957:36, pl. 2, figs. 1, 2 $[\mathrm{Pb}$ element $]$.

Hibbardella ortha Rexroad, 1958a:18, pl. 2, figs. 9-12 [Sa element].

Cavusgnathus unicornis-Rexroad, 1981:8, 9, pl. 1, figs. 17, 22, 26, 27 [Pa element, $\alpha$ morphotype], fig. 21 [Pa element, $\beta$ morphotype], figs. 18-20, 23 [Pa element, $\gamma$ morphotype], figs. 7, 8 [M element].

Cavusgnathus unicornis-Rexroad and Horowitz, 1990: 499 , pl. 1 , figs. $12,13,16,17$ [Pa element, $\alpha$ morphotypc], figs. $11,14,15 \quad[\mathrm{~Pa}$ element, $\beta$ morphotype], fig. 10 [Pa element, $\gamma$ morphotype], fig. 18 [Pa clement, $\alpha$ morphotype?], fig. 19 [Pa element, $\alpha-\beta$ intermediate morphotype] [includes synonymy].

\section{DIAGNOSIS}

Sec Rexroad (1981:8).

\section{HOLOTYPE}

State University of Iowa, 4174 (Youngquist and Miller, 1949, pl. 101, figs. 18, 19).

\section{TYPE HORIZON AND LOCALITY}

Pella beds, Chesterian age; Pella South West, Marrion County, Iowa, U.S.A.

\section{MATERIAL STUDIED}

Pa elements, $\alpha$ morphotype, 19(1); $\beta$ morphotype, 14(5); $\gamma$ morphotype, $8(1)$; intermediate morphotype, 14(2); indeterminate morphotype, $6(26)$. Pb elements, 10(7); M clements, 24(7); Sa elements, 2(7); Sb elements, (1); Sc elements, 1(1). Material from the Main Algal and Cambeck formations, Lower Border Group, the Cementstone Group, and the Orroland group.

\section{DESCRIPTION}

Pa elements. $\alpha$ morphotype, see Youngquist and Miller (1949:619) and Rhodes, Austin, and Druce (1969:82) under Cavusgnathus unicornis; $\beta$ morphotype, see Youngquist and Miller (1949:619) under $C$. regularis; $\gamma$ morphotype, see Rexroad (1957:17) under $C$. convexa.

Pb elements. See Rexroad (1957:36) under Ozarkodina compressa.

M elements. See Branson and Mehl (1941a:174) under Prioniodus varians and Rexroad (1957:34) under Neoprioniodus loxus. These forms represent end members of the range of variation in C. unicornis $\mathrm{M}$ elements.

Sa elements. See Rexroad (1958a:18) under Hibbardella ortha.

Sc elements. See Hass (1953:81) under Hindeodella ensis, and Clarke (1960:8) under H. tenuis.

\section{DISCUSSION}

The concept of $C$. unicornis followed herein is essentially the same as that of Rexroad (1981). Pa elements with a low blade, which in some specimens approaches the morphology of Cavusgnathus sp. sensu Rexroad (1981), are not uncommon in the Northumberland trough and are herein considered as variants of $C$. unicornis. Slight lateral offset of the anterior blade, encountered only rarely in the present study, is also considered to represent intraspecific variation (cf. Rexroad and Nicoll, 1965:18, pl. 1, figs. 2123). M elements of " $N$. loxus" and " $N$. varians" forms differ in little other than the angle of downward deflection of the posterior process (Rexroad, 1958a; Norby, 1976), although " $N$. varians" may be more robust (Norby, 1976). Both forms were considered by Rexroad and Horowitz (1990) to be morphotypes of M elements shared by C. unicornis and $C$. charactus (contra Rexroad, 1981). Both are included in $C$. unicornis herein. Some specimens develop an inclined basal cavity, which forms an anticusplike anterobasal termination. Similar anticusps are seen in Cavusgnathus $\mathrm{M}$ elements from the Bear Gulch Limestone, Montana (Conway Morris, 1990, fig. 7; pers. obs.).

A single Sb element in sample 1768701 has been tentatively assigned to $C$. unicornis. The presence of other cavusgnathid $\mathrm{Pa}$ elements with $C$. unicornis in this sample precludes more certain assignment.

\section{Cavusgnathus cf. hudsoni (Metcalfe, 1981)}

\section{MATERIAL STUDIED}

A single Pa element from the Bewcastle Formation, Lower Border Group.

\section{DESCRIPTION}

Apparatus unknown. The single sinistral specimen of $C$. cf. hudsoni ( $\gamma$ morphotype) differs from $C$. hudsoni in having a higher blade than $\gamma$ morphotypes of the species. It has very weak platform ornament and a lateral ridge along the left side of the blade as an anterior extension of the platform. The basal cavity does not reach the posterior end of the element; it bears thickened lips, the outer of which dips downwards.

\section{DISCUSSION}

This element may represent an extreme variant of $C$. hudsoni.

\section{Cavusgnathus cf. unicornis Youngquist and Miller, 1949}

Plate 2, Figs. 6a, b

\section{MATERIAL STUDIED}

A single Pa element from the Lower Antiquatonia Member of the Cambeck Formation, Lower Border Group. 


\section{DESCRIPTION}

The single Pa element specimen differs from $C$. unicornis only in the break up of the transverse ridges into nodes in the posterior half of the platform (a character usually seen only in $C$. naviculus), and in the suppression of parapet development in the posterior third of the element, to form a low flat broad posterior platform.

\section{DISCUSSION}

Some depression of the posterior part of the platform has been recorded in C. unicornis Pa elements (e.g., Rexroad, 1981, pl. 1, figs. 17, 22) although not to the extent to which it is developed in $C$. cf. unicornis. This specimen may, however, be an aberrant $C$. unicornis $\mathrm{Pa} \gamma$ element.

\section{Cavusgnathus? sp. a}

Plate 2, Fig. 8

\section{MATERIAL STUDIED}

2(1) Pa elements from the Cambeck Formation, Lower Border Group.

\section{DESCRIPTION}

Apparatus unknown. Pa elements bear a short anterior blade, free for almost all its length. The blade is composed of a large cusp with a smaller "piggy back" denticle to the anterior. Blade height is approximately twice its length. One specimen has a small denticle posterior of the cusp. The platform is higher than it is wide and is omamented with low indistinct nodes, which become more discrete posteriorly. The medial trough is shallow and narrow, shallowing posteriorly and more or less closed anteriorly by convergence of the left parapet with the blade. In lateral view, the lower surface of these elements is straight or concave, and the upper surface of the platform is convex. The two most complete specimens recovered are sinistrally curved. The lanceolate basal cavity is subsymmetrical and would almost certainly extend to the posterior tip of complete specimens. It is deepest and widest just anterior of midlength and, although constricted anteriorly, it extends under the blade. Posteriorly the cavity tapers gradually.

\section{DISCUSSION}

These specimens resemble some Pa elements of Clydagnathus windsorensis (Globensky) but lack the discrete nodose ornament diagnostic of the genus.
Genus Clydagnathus Rhodes, Austin, and Druce, 1969

Clydagnathus Rhodes, Austin, and Druce, 1969:84.

\section{DIAGNOSIS}

See Rhodes, Austin, and Druce (1969:84).

\section{TYPE SPECIES}

Clydagnathus cavusformis Rhodes, Austin, and Druce, 1969 , by original designation.

\section{DISCUSSION}

Rhodes, Austin, and Druce (1969:85) distinguished Clydagnathus from Cavusgnathus "by the general anterior closure of the oral trough, by the merging of the marginal ornament with the blade and by the lateral, rather than longitudinal expansion of the basal cavity." After examination of large numbers of Clydagnathus from Australia, however, Nicoll and Druce (1979) concluded that the genera could not be differentiated using these characters. Sandberg and Ziegler (1979) considered Clydagnathus and Cavusgnathus to be distinguishable solely in terms of their respective stratigraphic positions. With the reassignment of Cavusgnathus windsorensis Globensky to Clydagnathus (von Bitter and Plint, 1987) and the recognition of Cavusgnathus of Tournaisian age (see Cavusgnathus hudsoni above), this stratigraphic distinction can no longer be made.

The possession of nodose rather than ridged platformelement ornament has been used to differentiate Clydagnathus from Cavusgnathus herein. This appears to be in accord with the generic concept used by other workers (e.g., Nicoll and Druce, 1979; von Bitter and Plint, 1987) but a distinction at the generic level based on this character is probably unjustified (see discussion of the family Cavusgnathidae). In addition, Clydagnathus may be polyphyletic. A phylogenetic sequence from "Spathognathodus" plumulus (Rhodes, Austin, and Druce) through Clydagnathus gilwernensis Rhodes, Austin, and Druce to Clydagnathus cavusformis has been proposed (Rhodes, Austin, and Druce, 1969; Austin and Hill, 1973; Sandberg and Ziegler, 1979). However, Sandberg and Ziegler (1979) suggest that Clydagnathus ormistoni (Beinert, Klapper, Sandberg, and Ziegler) evolved from Pandorinellina cf. insita (Stauffer) or Scaphignathus ziegleri Druce. Preliminary evidence suggests that Clydagnathus windsorensis (Globensky) may be a progenetic offshoot of Cavusgnathus (see discussion of $\mathrm{Cl}$. windsorensis). Generic revision of Clydagnathus is clearly required but must await description of the apparatus of the type species, $\mathrm{Cl}$. cavusformis. 
Clydagnathus windsorensis (Globensky, 1967)

Plate 2, Figs. 9-15

[v*] Cavusgnathus windsorensis Globensky, 1967:439, pl. 57, figs. $3,4,7,9,11,19$, pl. 58, fig. 1 [Pa elements] [N.B. The specimen shown in pl. 57, fig. 7 is not the holotype].

[v.] Cavusgnathus cf. windsorensis Globensky, 1967:439, pl. 57, figs. 2, 6, 10 (specimen lost); 12, pl. 58, fig. 8 [Pa elements].

[vp] Cavusgnathus spp. Globensky, 1967:440, pl. 57, fig. 17 only [Pa element].

[v?] Ozarkodina sp. A Globensky, 1967:446, pl. 55, figs. 1, 5, 12 oniy [ $\mathrm{Pb}$ elements].

[p?] Taphrognathus varians Branson and Mehl-Pierce and Langenheim, 1974:168, 169, pl. 1, figs. 3, 4, 6, 7 only [Pa elements].

[vp] Cavusgnathus windsorensis-von Bitter and Plint-Geberl, 1982:194, pl. 2, figs. 1-3, 16-18 [Pa elements]; pl. 6, fig. 18 [M element] only.

[vp?] Cavusgnathus windsorensis-von Bitter and Plint-Geberl, 1982:194, pl. 1, figs. 1-16; pl. 2, figs. 4-15 [Pa elements]; pl. 7, figs. 1, 5-7 [Pb elements]; pl. 3, figs. 15 , 16 [Sa clements]; pl. 7, fig. 12 [Sb element]; figs. 15-18 [Sc elements].

[vp] Cavusgnathus regularis type-von Bitter and Plint-Geberl, 1982:197, pl. 3, fig. 18 only [Pa element].

[vnonp] Cavusgnathus windsorensis-von Bitter and Plint-Geberl, 1982, pl. 7, fig. 2 only [= Vogelgnathus pesaquidi, $\mathrm{Pa}$ element].

[(?)] Clydagnathus? cf. cavusformis Rhodes, Austin, and Druce-Briggs, Clarkson, and Aldridge, 1983:3-8, figs. 1, 2, 3 [whole animal].

Cavusgnathus windsorensis - von Bitter and Austin, 1984, pl. 19, figs. 1-10 [Pa elements].

[v.] Clydagnathus windsorensis-von Bitter and Plint, 1987:350, 351, figs. 2.1-2.6, 2.7(specimen lost), 2.10, 2.11, 2.14-2.17 [Pa elements], fig. 2.12, [Pb element], fig. 2.13 [M element], fig. 2.8 [Sa element], fig. 2.19 [Sb element], fig. 2.18 [Sc element].

[(?)] Clydagnathus? cf. cavusformis-Aldridge, 1987, fig. 1.9 [whole animal] [cop. Briggs, Clarkson, and Aldridge, 1983, figs. 1A, 3B].

\section{DIAGNOSIS}

See von Bitter and Plint (1987:351).

\section{HOLOTYPE}

University of New Brunswick 64-F-235 (Globensky, 1967, pl. 57, figs. 3, 4, 7).

\section{TYPE HORIZON AND LOCALITY}

Windsor Limestone, sample KD10 of Globensky (1967). On the Atlantic coast between the village of Skir Dhu and north shore about $330 \mathrm{~m}$ SW of Skir Dhu fisherman's wharf, Skir Dhu, Cape Breton Island, Nova Scotia, Canada.

\section{MATERIAL STUDIED}

$\mathrm{Pa}$ elements, 63(14); $\mathrm{Pb}$ elements, 15(8); M elements, 8(1); Sa elements, 4; Sb elements, 7(1); Sc elements, 12(6); mosuly from the lower Lynebank Formation, Lower Border Group, but also from the Cambeck Formation, Lower Border Group, the Southerness and Basal Cementstone formations, Cementstone Group, and the Cementstone Group of Kielder Bum, Barrow Scar, and Black Burn.

\section{DESCRIPTION}

Pa elements. Sce Globensky (1967:439) under Cavusgnathus windsorensis, and the remarks of von Bitter and Plint (1987:351).

$\mathrm{Pb}$ elements. The anterior process is laterally compressed. It is straight or downcurved, generally only slightly, and occasionally incurved slightly. It becomes thicker towards the cusp and bears up to seven, commonly five, laterally compressed, elongate pointed denticles which are free for most of their length. The denticles are erect and slightly recurved, often becoming slightly reclined towards the cusp, and are highest around the middle of the process. The cusp is higher wider and thicker than the anterior denticles. It is reclined and recurved although usually not greatly so. The posterior process is lower than, but approximatcly equal in length to, the anterior, and may be less laterally compressed. It is straight or slightly downcurved, thins posteriorly, and bears five or six laterally compressed denticles. These denticles are subequal in size, generally smaller than those of the anterior process, and become increasingly reclined posteriorly. The basal cavity is relatively large. It is widest and deepest beneath the posterior edge of the cusp, and tapers posteriorly to a point at least half-way along the process. Anteriorly the cavity tapers a variable distance, but generally reaches a point approximately half-way along the process. The lips of the cavity often extend downwards, creating an undulating lower profile to the element.

M elements. The cusp is strongly proclined, its long axis forming an angle of approximately $130^{\circ}$ with the axis of the posterior process. It is slightly incurved and laterally compressed, with sharp anterior and posterior edges and convex lateral surfaces. The posterior process is usually straight but may be curved at the anterior end where it joins the cusp. The thickness of the process decreases towards the posterior tip; its length may be greater than or less than that of the cusp. Depending on length, the process bears up to 10 small discrete pointed subequal denticles, that generally become more erect with respect to 
the process posteriorly. The small asymmetrical basal cavity is widest beneath the posterior part of the cusp, and has a small, occasionally thickened lip on the inner side. The cavity tapers posteriorly to a narrow groove extending down the sharp lower edge of the process. In a few specimens, one or two small fused denticles are developed anterior of the cusp.

Sa elements. See Rexroad (1958a: 18) under Hibbardella ortha.

$\mathrm{Sb}$ elements. The anterior process is laterally compressed and straight or slightly incurved. It bears six or more laterally compressed denticles, free for most of their length, which curve inwards and become increasingly reclined posteriorly. The sharply pointed cusp is laterally compressed, reclined and incurved, and is larger than the anterior denticles. The posterior process is laterally compressed, straight, and larger than the anterior process. It bears up to approximately 10 laterally compressed denticles; these increase in size and reclination towards the posteriormost denticles, which may be larger than the cusp. The posterobasal termination beneath these denticles may be downturned. The basal cavity is small and is located to the anterior of the cusp, aligned with its long axis. It continues as a narrow groove along the sharp lower edge of the posterior process and part way along the anterior. In larger specimens, the groove is flanked by recessive basal margin.

Sc elements. See Clarke (1960:8) under Hindeodella tenuis.

\section{DISCUSSION}

The apparatus of Clydagnathus windsorensis from the Northumberland trough was reconstructed from essentially monospecific faunas recovered from three samples of the Ellery Sike Limestone Member of the Lynebank Formation, Lower Border Group. Certain morphological similarities, especially the elongate narrow cusps of the nonplatform elements, provide additional evidence of affinity.

Although similar to the type material (Globensky, 1967) and some of the material figured by von Bitter and PlintGeberl (1982), Cl. windsorensis $\mathrm{Pa}$ elements from the Northumberland trough are different from specimens from the Diplognathodus Zone in southwest Newfoundland (von Bitter and Plint-Geberl, 1982, pl. 1, figs. 1-16, pl. 2, figs. 4-15). The latuer elements belong to an apparatus that appears to lack $\mathrm{M}$ elements, has abbreviated $\mathrm{Pb}$ elements, and has an Sa element that may have lacked a posterior process (von Bitter and Plint-Geberl, 1982). Although these differences were considered to be intraspecific ecophenotypic variation (von Bitter and Plint-Geberl, 1982), Diplognathodus Zone specimens may prove to represent a different species.

In the Northumberland trough, stratigraphically younger specimens from the Cambeck Formation have blunter nodes, relatively longer, more arched platforms, and very short high blades, compared with specimens from the Lynebank Formation.

von Bitter and Plint (1987) included "Ozarkodina acadiensis Globensky" in synonymy with $\mathrm{Cl}$. windsorensis as the $\mathrm{Pb}$ element. The figured specimens of Globensky (1967) have an incurved posterior process, a character not observed in other $\mathrm{Cl}$. windsorensis $\mathrm{Pb}$ elements. They are probably the $\mathrm{Pb}$ elements of Lochriea scotiaensis (Globensky). Five $\mathrm{Pb}$ elements from the Lynebank Formation are questionably assigned to $\mathrm{Cl}$. windsorensis herein, as they have a larger number of denticles and a smaller cusp than is usually seen in this species.

The $\mathrm{M}, \mathrm{Sa}$, and $\mathrm{Sc}$ elements of $\mathrm{Cl}$. windsorensis are similar to the homologous elements of species of Cavusgnathus and Taphrognathus varians.

The preference of $\mathrm{Cl}$. windsorensis for shallow restricted probably euryhaline environments is well documented (e.g., Plint and von Bitter, 1986; Purnell, 1989). Gould (1977:324-325) argued that progenesis represents an effective adaptive strategy in such environments. The close morphological similarity between $\mathrm{Cl}$. windsorensis elements, which are generally rather small, and juvenile Cavusgnathus elements suggests that $\mathrm{Cl}$. windsorensis evolved as a progenetic offshoot of Cavusgnalhus. The species is now known from strata of Chadian (this study) and Holkerian age (von Bitter and Austin, 1984; this study) and a progenetic response to environmental stress may, therefore, have occurred more than once.

\section{Genus Patrognathus Rhodes, Austin, and Druce, 1969}

Patrognathus Rhodes, Austin, and Druce, 1969:178.

Capricornognathus Austin in Austin and Mitchell, 1975:47.

\section{DIAGNOSIS}

See Rhodes, Austin, and Druce (1969:178).

\section{TYPE SPECIES}

Patrognathus variabilis Rhodes, Austin, and Druce, 1969, by original designation.

\section{DISCUSSION}

The diagnosis of Capricornognathus Austin (in Austin and Mitchell, 1975) corresponds closely to the description of Taphrognathus capricornis Druce of Druce (1970). Klapper (1971) noted the similarity between $T$. capricornis and Patrognathus and suggested that $T$. capricornis may be a younger representative of the genus. Indeed, Capricornognathus, according to the diagnosis of Austin (in Austin and Mitchell, 1975) differs from Patrognathus sensu Klapper (1971) only in that the former taxon may have ridged or nodose platform ornament and may possess a short posterior free blade and carina. In vicw of the overwhelming similarities between T. capricornis and Patrognathus, $T$. 
capricornis, the type and only species of Capricornognathus, is hercin placed in Patrognathus as it was by Metcalfe $(1980,1981)$ and Varker and Sevastopulo (1985).

Although $P$. capricornis is partially reconstructed herein, there is little evidence for the nature of the apparatus in other species of the genus, the type species included. Consequently, expansion of the generic diagnosis to include nonplatform elements would be premature. If the apparatus of $P$. variabilis Rhodes, Austin, and Druce proves significantly different from $P$. capricornis, another generic assignment must be sought for the latter species.

Patrognathus $\mathrm{Pa}$ elements are distinguished from those of other cavusgnathid genera by the presence of a medial anterior blade, free for all its length, with the highest denticle at the posterior end of the blade (Klapper, 1971). Some Pa elements of Taphrognathus? transatlanticus (von Bitter and Austin) have a similar blade profile, but the blade is a continuation of the outer parapet (von Bitter and Austin, 1984).

Patrognathus capricornis (Druce, 1970)

Plate 3, Figs. 1-9

[(?)] Taphrognathus sp. Druce, 1969:139, pl. 41, fig. 1 [Pa element].

Taphrognathus capricornis Druce, 1970:102, pl. 15, figs. 3-5 [Pa elements].

[?] Patrognathus? cf. capricornis—Jenkins, 1974:916 [Pa element] [not figured].

[v.] Taphrognathus capricornis-Austin, 1974, pl. 1, figs. 6, 19 [Pa elements].

[v(?)] Patrognathus andersoni-Austin, 1974, pl. 1, fig. 5 [? juvenile Pa element].

[v.] Capricornognathus capricornis-Austin in Austin and Mitchell, 1975:48, pl. 2, figs. 5-12, 14-19, 21, 23, 28, 30-33 [Pa elements; N.B. magnification of specimens between $\times 50$ and $\times 60$, not $\times 40$ ] [figs. 9, 12 cop. Austin, 1974, pl. 1, figs. 19, 6].

[v.] Patrognathus andersoni Klapper-Austin in Austin and Mitchell, 1975:52, pl. 2, figs. 3, 4, 13, 20, 22, 25 [Pa elements], figs. 1, 2, 24, 27 [? juvenile Pa elements; N.B. magnification of specimens between $\times 50$ and $\times 60$, not x40] [fig. 2 cop. Austin, 1974, pl. 1, fig. 5].

[v.] Neoprioniodus cf. confluens (Branson and Mehl) - Austin in Austin and Mitchell, 1975:45, table 2 [M element; not figured].

Patrognathus capricornis-Metcalfe, 1980, pl. 13, figs. 1, 2 [Pa element], fig. 3 [? juvenile Pa element].

[v.] Patrognathus capricornis-Metcalfe, 1981:39, pl. 9, figs. 1, 2 [Pa elements]. [v.] Capricornognathus capricornis-Austin and Rhodes in Robison, 1981:159, text-fig. 108,5 [Pa element] [cop. Austin in Austin and Mitchell, 1975, pl. 2, figs. 10, 33].

Patrognathus variabilis Rhodes, Austin, and DruceAustin and Davies, 1984:207, text-fig. 15, pl. 1, figs. 10, 11 [Pa elements], fig. 8 [?juvenile Pa element].

[v.] Patrognathus capricornis-Varker and Sevastopulo, 1985, pl. 5.6, fig. 17 [Pa element] [cop. Metcalfe, 1981, pl. 9, fig. 1a].

[v.p] Mestognathus beckmanni Bischoff-Armstrong and Purnell, 1987, pl. 3, fig. 5 [Pb element], fig. 7 [M element] only.

[v.p] Patrognathus variabilis-Armstrong and Purnell, 1987, pl. 3, figs. 8, 9 [?juvenile Pa elements], fig. 10 [Sc element], fig. 11 [M element] only.

\section{REVISED DIAGNOSIS}

Apparatus at least quinquemembrate. Pa elements carminiscaphate, straight or slightly curved, with shallow central trough; left parapet bears one or two rows of rounded nodes; right parapet bears a single row of transverse ridges or tetrahedral nodes. $\mathrm{Pb}$ clements angulate; $\mathrm{M}$ elements dolabrate; Sa element alate; Sc elements bipennate. Pa elements paired with class IIla symmetry; all others, apart from the Sa element, symmetrically paired.

\section{HOLOTYPE}

Bureau of Mineral Resources, Canberra, CPC 7796 (Druce, 1970, pl. 15, fig. 5).

\section{TYPE HORIZON AND LOCALITY}

Gargoogie Oolite Member, Rockhampton Group, Queensland, Australia (G.R. 322093, Rockhampton Sheet).

\section{MATERIAL STUDIED}

$\mathrm{Pa}$ elements, 16(1), juvenile $\mathrm{Pa}$ elements (Patrognathus sp. in Appendix II), 18(3); Pb elements, 5(1); M elements, 10(6); Sb elements, (1); Sc elements, 5(24). Mostly from the Bogside Limestone Member of the Bewcastle Formation but also from the Lynebank and Cambeck formations, Lower Border Group, the Southerness Formation, Cementstone Group, and the Orroland Group. In addition, the material of Austin (in Austin and Mitchell, 1975) and unpublished material collected by Dr. N. J. Riley from the Craven basin has been examined.

\section{DESCRIPTION}

Pa elements. See Metcalfe (1981:39).

Pb elements. See Rexroad (1957:36) under Ozarkodina compressa. Patrognathus capricornis $\mathrm{Pb}$ elements have a longer straighter anterior process than typical " $O$. compressa"-form $\mathrm{Pb}$ elements. This process bears between eight and ten subequal denticles and has a square anterobasal termination. The cusp and denticle shape 
resemble those of the anterior blade of $\mathrm{Pa}$ elements of the species.

M elements. See Rhodes, Austin, and Druce (1969:158, 159) under Neoprioniodus confluens.

Sa elements. See Rexroad (1958a:18) under Hibbardella ortha.

Sc elements. See Hass $(1953: 81,82)$ under Hindeodella ensis, and Clarke (1960:8) under H. tenuis. The size of denticles on the posterior process of these elements alternates more regularly than in other cavusgnathids.

\section{DISCUSSION}

The apparatus of Patrognathus capricornis was reconstructed on the evidence of nonplatform elements associated with Patrognathus $\mathrm{Pa}$ elements in the low diversity faunas of the Northumberland trough. It is also assumed that $P$. capricornis had a typical ozarkodinid Bauplan similar to other cavusgnathids. Unfortunately, $\mathrm{Pa}$ elements of Taphrognathus varians and Mestognathus often occur with Patrognathus, and reduce the level of confidence that can be placed in the assignment of some of the elements. For example, although distributional and morphological evidence suggests that the $\mathrm{Pb}$ elements described above belong to $P$. capricornis, there is a possibility that they represent juvenile Mestognathus $\mathrm{Pb}$ elements. Similarly, some of the $\mathrm{M}$ elements assigned to $P$. capricornis may belong to Mestognathus.

One of the specimens figured as $P$. capricornis (PI. 3, Fig. 6) resembles some Adetognathus unicornis $\mathrm{Pa}$ elements (e.g., Varker and Austin, 1974, pl. 6, fig. 18) and illustrates the problems of homeomorphy in the Cavusgnathidae.

$M$ elements do not have the long anticusp of the lectotype of "Neoprioniodus confluens (Branson and Mehl)" also developed in one of the figured specimens of Rhodes, Austin, and Druce (1969, pl. 21, fig. 8). They are similar to the other figured specimen of Rhodes, Austin, and Druce (1969, pl. 21, fig. 2), and otherwise conform to their description. $\mathrm{M}$ elements of "Neoprioniodus confluens" form are consistently associated with $P$. capricornis $\mathrm{Pa}$ elements in the Northumberland trough, and also occur with $P$. capricornis in Northern Ireland (identified as $N$. cf. confluens by Austin in Austin and Mitchell, 1975, but not figured). M elements of this form also occur with $P$. variabilis Pa elements (Austin and Hill, 1973).

Sa elements of "Hibbardella ortha Rexroad"-form occur with Patrognathus $\mathrm{Pa}$ elements in the Bogside Limestone Member and are tentatively included within the apparatus. Taphrognathus varians Branson and Mehl also bore " $H$. ortha" Sa elements and the specimens occurring with Patrognathus may belong to $T$. varians. Alternatively, this element may be vicariously shared by the two species-vicarious, as used herein, refers to the presence of morphologically indistinguishable elements in two or more species of conodont (Klapper and Philip, 1971). Because of these uncertainties the possible Sa elements of Patrognathus are included in $T$. varians in Appendix II.

A single poorly preserved Sb element fragment, similar to a $T$. varians $\mathrm{Sb}$ element, was recovered in association with Patrognathus in this study. This element may belong to the apparatus. Sc elements assigned to $P$. capricornis resemble Sc elements of $T$. varians. Given the association of these Sc elements with Patrognathus Pa elements and the regular alternation of denticle size, similar to that of $P$. capricornis $\mathrm{M}$ elements, they probably belong to the latter species.

\section{ONTOGENY}

Pa elements of $P$. capricornis can be distinguished from other members of the genus primarily by the presence of ridges or tetrahedral nodes on the right parapet. However, the material studied and published plates clearly show that platform ornament changed through ontogeny. In very small specimens (Text-Fig. 6a; Pl. 3, Fig. 4), the right parapet is poorly developed compared to the left. As size increases, both parapets are equally developed and bear rounded nodes (Text-Fig. 6b; Pl. 3, Fig. 3). At an element length of approximately $0.5 \mathrm{~mm}$ to $0.6 \mathrm{~mm}$, the nodes of the right parapet develop a sharp angular inner surface and become tetrahedral in shape (Text-Fig. 6c; Pl. 3, Fig. 7). These tetrahedral nodes then become more transversely elongate and develop into the ridges of mature elements (Pl. 3, Fig. 6). Finally, in most specimens approaching $0.85 \mathrm{~mm}$ to $0.9 \mathrm{~mm}$ in length, a second row of small nodes develops in the posterior part of the left parapet (Text-Fig. 6d).

Austin (in Austin and Mitchell, 1975) noted the similarity of small Pa elements of $P$. capricornis and $P$. variabilis Rhodes, Austin, and Druce to $P$. andersoni Klapper, and suggested that " $P$. andersoni could be a growth stage of both $C$. capricornis and $P$. variabilis" (Austin in Austin and Mitchell, 1975:52). However, neither $P$. capricornis nor $P$. variabilis was associated with $P$. andersoni in the study of Klapper (1971). Furthermore, all the specimens figured by Klapper (1971), except one, exceed $0.7 \mathrm{~mm}$ in length (calculated from plate) but do not appear to have tetrahedral nodes. Thus, small $\mathrm{Pa}$ elements of the three Carboniferous species of Patrognathus cannot be distinguished until adult characters start to develop (cf. Austin in Austin and Mitchell, 1975). Specimens of less than approximately $0.5 \mathrm{~mm}$ to $0.6 \mathrm{~mm}$ in length that lack the large flaring basal cavity of $P$. variabilis and the tetrahedral nodes of $P$. capricornis, and do not occur with specimens exhibiting adult characters of these species, 


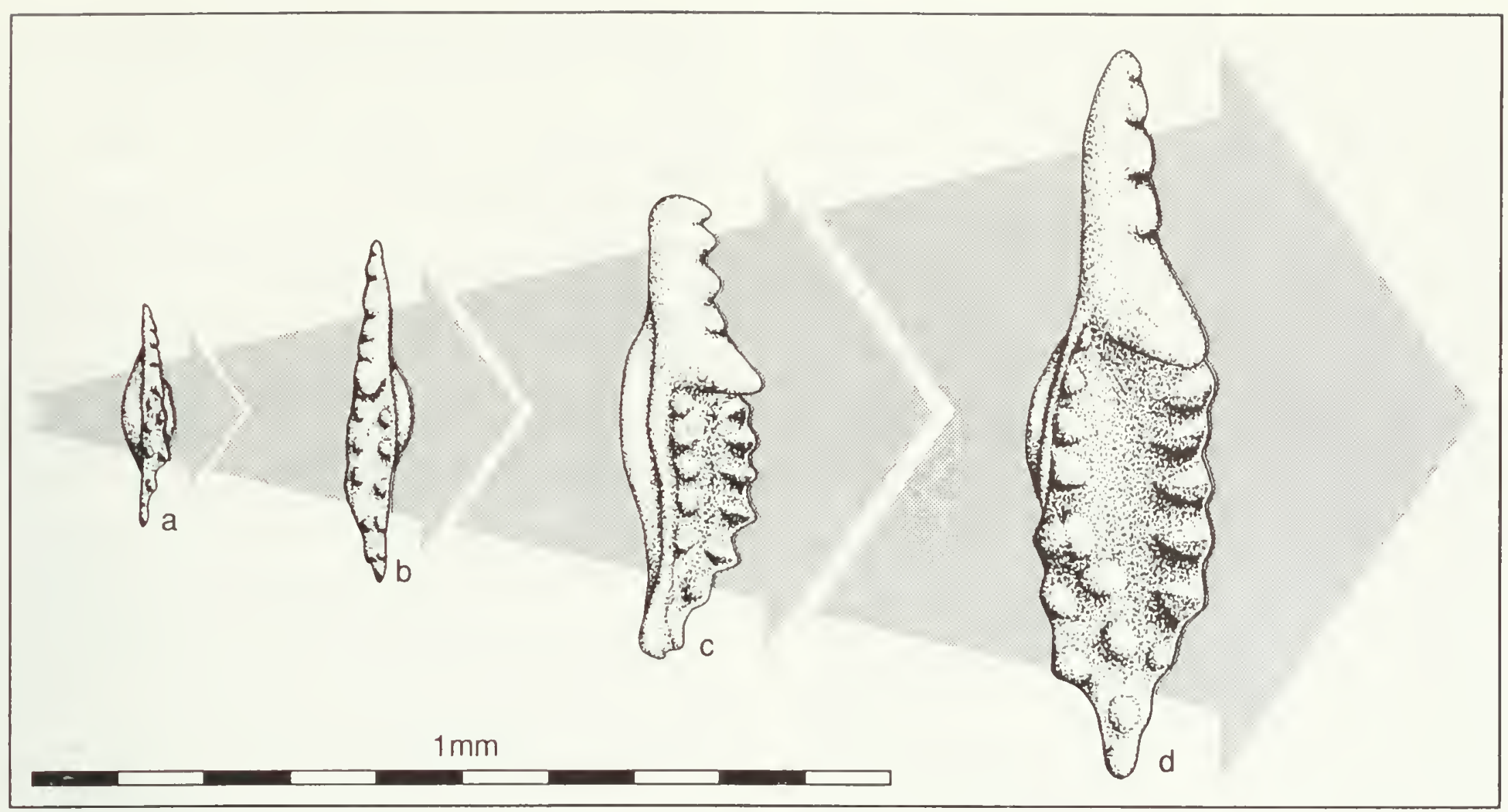

TEXT-FIG. 6. Ontogeny of Pa elements of Palrognathus capricornis. Figures based on actual specimens, broken parts restored: a) ROM 48814; b) ROM 48813; c) ROM 48810; d) Mil(c)565/17 (Austin and Mitchell, 1975, pl. 2, figs. 5, 19, 21).

should be assigned to Patrognathus sp. (c.g., Matthews and Naylor, 1973:356, pl. 35, figs. 12, 13; Lipnjagov, 1979, pl. 2, fig. 11; Kononova in Wagner, Higgins, and Meyen, 1979, pl. 1, fig. 17; Nicoll and Druce, 1979:28, pl. 15, figs. 3, 4). The similarity between different Pa element growth stages of these three species of Patrognathus suggests peramorphic evolution of $P$. capricornis.

\section{Genus Taphrognathus Branson and Mehl, 1941}

Taphrognathus Branson and Mehl, $1941 \mathrm{~b}: 181$.

[non] Taphrognathus Welles, 1947.

Cloghergnathus Austin in Austin and Mitchell, 1975:48.

\section{REVISED DIAGNOSIS}

Apparatus seximembrate when fully developed. Pa elements carminiscaphate to anguliscaphate with conspicuous central trough; anterior free blade medial or lateral; parapets nodose, transversely ridged or smooth; basal cavity bilaterally symmetrical to moderately asymmetrical. $\mathrm{Pb}$ elements angulate; $\mathrm{M}$ elements dolabrate; Sa element alate; $\mathrm{Sb}$ elements bipennate; $\mathrm{Sc}$ elements bipennate. $\mathrm{Pa}$ elements paired with Class 11I, rarely Class II, symmetry; all other elements, apart from the $\mathrm{Sa}$, symmetrically paired.

\section{TYPE SPECIES}

Taphrognathus varians Branson and Mehl, 194 lb, by original designation.

\section{DISCUSSION}

The diagnosis of Taphrognathus is expanded to include nonplatform elements. The reconstruction is based on the nonplatform elements associated with Taphrognathus $\mathrm{Pa}$ elements in the low diversity faunas recovered from the Northumberland trough. Taphrognathus carinatus (Higgins and Varker) as reconstructed by Higgins and Varker (1982) is in broad agreement with this. It is assumed that Taphrognathus had a typical ozarkodinid Bauplan similar to previously reconstructed cavusgnathids.

Taphrognathus $\mathrm{Pa}$ elements exhibit considerable variation in many aspects of their morphology (Branson and Mehl, 1941b; Thompson and Goebel, 1969; Thompson and Fellows, 1970; Nicoll and Rexroad, 1975). In the U.S.A. this variation follows no stratigraphic or geographic pattern (Thompson and Goebel, 1969; Nicoll and Rexroad, 1975). In erecting Taphrognathus as a monospecific genus, Branson and Mehl (1941b) considered medial anterior blade position to be diagnostic. Consequently, the variation in blade position recorded in every documented occurrence of Taphrognathus has caused some taxonomic confusion. The majority of authors have either included 
forms showing lateral migration of the blade within Taphrognathus or considered them to be intermediate with Cavusgnathus (see Table 3). Austin (in Austin and Mitchell, 1975) erected the genus Cloghergnathus to accommodate lateral blade forms.

Study of the type material and generic diagnoses of Taphrognathus and Cloghergnathus reveals that they are differentiated only by blade position. Sound taxonomic characters should be recognizable throughout the ontogeny of an organism, show a minimum of variation within populations, and not be readily modified by the environment (Blackwelder, 1967; Raup and Stanley, 1978). Blade position in Taphrognathus and Cloghergnathus fulfils none of these criteria (see discussion of $T$. varians). The value of blade position as a taxonomic character is further undermined by the discordant nature of variation in the character. Taxonomic subdivisions defined on blade position, both within and between Cloghergnathus and Taphrognathus, do not correlate with the variation exhibited by other characters. Also, shifts in blade position are known to occur iteratively in the Cavusgnathidae (Druce, 1970; Austin, 1973; Mapes and Rexroad, 1986), making blade position a poor character on which to differentiate genera. Detailed palaeoecological analysis also indicates that the type species of
Cloghergnathus, C. globenskii Austin, is an ecophenotype of $T$. varians (see discussion of $T$. varians). Therefore, the concept of Taphrognathus is expanded to include $\mathrm{Pa}$ elements with lateral blades, previously assigned to Cloghergnathus.

Platform-element symmetry may be of importance in both phylogeny (Lane, 1968) and functional morphology of conodonts (Aldridge et al., 1987; Nicoll, 1987). The symmetry of the $\mathrm{Pa}$ element pair has therefore been included in the revised diagnoses of $T$. varians and $T$. carinatus. Of the other species of Taphrognathus, $T$. cravenus (Metcalfe) Pa elements have medial to right blade development and a flared right parapet, probably pairing with Class IIIa symmetry. Taphrognathus rhodesi is known only from two specimens (Austin in Austin and Mitchell, 1975), and its symmetry cannot be determined. Although the close spacing of platform ribs diagnostic of T. rhodesi is rarely approached in other species of the genus, the status of a species of Taphrognathus based on only two specimens is questionable.

The concept of Taphrognathus discussed above confirms the homeomorphic relationship with Adetognathus Lane noted by previous authors (Rexroad, 1958b; Austin in Austin and Mitchell, 1975; Higgins and Varker, 1982) (see discussion of the Cavusgnathidae).

TABLE 3. Variation in blade position of Taphrognathus varians recorded by previous authors.

\begin{tabular}{|c|c|c|c|}
\hline Author & Location & $\begin{array}{l}\text { Number of } \\
T \text {. varians }\end{array}$ & $\begin{array}{l}\text { Number of Taphrognathids with } \\
\text { Lateral Blades }\end{array}$ \\
\hline Branson and Mehl, 1941 & Iowa, Missouri & $>74$ & $1 T$.varians? \\
\hline Rexroad and Collinson, 1963 & $\begin{array}{l}\text { Illinois, Indiana, } \\
\text { Kentucky }\end{array}$ & 16 & $\begin{array}{l}11 \text { Taphrognalhus-Cavusgnathus } \\
\text { transitions }\end{array}$ \\
\hline Rexroad and Collinson, 1965 & Illinois & 297 & $0 ?$ \\
\hline Thompson and Goebel, 1968 & Kansas & $>300$ & 9 Taphrognathus sp. \\
\hline Thompson and Fellows, 1970 & $\begin{array}{l}\text { Missouri, Arkansas, } \\
\text { Oklahoma }\end{array}$ & 12 & 1 New genus new species \\
\hline Nicoll and Rexroad, 1975 & Indiana & 678 & $\begin{array}{l}<10 \text { T. varians } \\
\text { Iransitional to Cavusgnathus }\end{array}$ \\
\hline Austin and Mitchell, 1975 & Northern Ireland & 2 & 15 Cloghergnathus \\
\hline Higgins and Varker, 1982 & Ravenstonedale & unknown & unknown Cloghernathus carinalus \\
\hline Armstrong and Pumell, 1987 & North Cumbria & 12 & $\begin{array}{l}194 \text { Cloghernathus } \\
21 \text { Cloghergnathus-Taphrognathus } \\
\text { intermediates }\end{array}$ \\
\hline This study & $\begin{array}{l}\text { Northumberland, } \\
\text { North Cumbria }\end{array}$ & $\begin{array}{l}15 \\
\text { (morphotype I) }\end{array}$ & $\begin{array}{l}292 \text { Taphrognathus varians } \\
\text { (morphotypes II and III) }\end{array}$ \\
\hline
\end{tabular}


Taphrognathus carinatus (Higgins and Varker, 1982)

Plate 3, Figs. 10-15; Plate 4, Fig. 1

[v*p] Cloghergnathus carinatus Higgins and Varker, 1982:160, 161 , pl. 18 , figs. $1-3,7-9,11$ only [Pa elements].

[v.p] Cloghergnathus non-platform elements Higgins and Varker, 1982:161, pl. 18, fig. 18 [Pb element], fig. 19

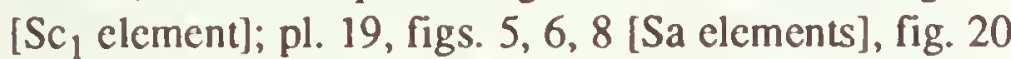
[ $\mathrm{Sc}_{2}$ element] only [all referred to as Cloghergnathus carinatus in plate caption].

[vnonp] Cloghergnathus carinatus Higgins and Varker, 1982:160, 161 , pl. 18 , figs. $4-6,10$ only.

[vnonp] Cloghergnathus non-platform elements Higgins and Varker, 1982:161, pl. 19, figs. 4, 18 only [referred to as Cloghergnathus carinatus in plate captions].

[v.] Lonchodina sp. Higgins and Varker, 1982:164, pl. 18, fig. 17; pl. 19, figs. 1-3 [Sb elements].

[v.] Neoprioniodus sp. Higgins and Varker, 1982:164, pl. 19, fig. 17 [M element].

[v.] Cloghergnathus carinatus-Varker and Sevastopulo, 1985:200, pl. 5.5, figs. 6, 8, 10 [Pa elements] [cop. Higgins and Varker, 1982, pl. 18, figs. 1, 2, 7].

\section{REVISED DIAGNOSIS}

Platform elements arched with short inner lateral or medial anterior blade one-quarter to onc-fifth of element length; blade convex and crestlike, extending above hcight of parapets but equal in height at its posterior end to the inner parapet; parapets nodose or transversely ridged; medial carina developed in posterior quarter of central trough; symmetry Class IIIb dominant.

\section{HOLOTYPE}

British Museum, R30 (Higgins and Varker, 1982, pl. 18, figs. 2, 7).

\section{TYPE HORIZON AND LOCALITY}

Scandal Beck Limestone, sample SB2 of Higgins and Varker (1982), Ravenstonedale, Cumbria, U.K. (G.R. NY 722044).

\section{MATERIAL STUDIED}

$\mathrm{Pa}$ elements, 16(4); $\mathrm{Pb}$ elements, 11; M elements, 3; Sa elements, 23(1); Sb elements, 5(1); $\mathrm{Sc}_{1}$ elements, 5(6); $\mathrm{Sc}_{2}$ elements, 11(2); all, apart from $2 \mathrm{~Pa}$ elements, from the Cementstone Group of the Rothbury area.

\section{DESCRIPTION}

Pa elements. See Higgins and Varker (1982:160).

$\mathrm{Pb}$ elements. The anterior process bears up to five laterally compressed denticles which may be long and discrete or rather short. The reclined cusp is also laterally compressed and is taller and broader than the anterior denticles. The posterior process is about half the length and height of the anterior and bears three short denticles. Both processes and the base of the cusp are laterally thickened, with distinct shoulders developed alongside the denticles nearest the cusp. The processes taper distally and have a slight inward flexure. The basal cavity is deep and surrounded by thickened lips that pass laterally into thin zones of recessive basal margin along the narrow lower edge of the processes. The cavity tapers anteriorly and posteriorly, extending as a groove along the processes.

M elements. See Higgins and Varker (1982:161) under Neoprioniodus sp.

Sa elements. Sce Higgins and Varker (1982:161, 162) under Cloghergnathus $\mathrm{A}_{3}$ element. The elements figured by Higgins and Varker (1982) are missing the end of the posterior process. Examination of the specimens, however, suggests that the process was almost certainly short. The same is true of specimens from the Northumberland trough, with the process reduced to a small swelling at the base of the cusp in some specimens (e.g., Pl. 3, Fig. 13).

Sb elements. Sce Higgins and Varker (1982:161) under Lonchodina sp.

$\mathrm{Sc}_{1}$ elements. These elements are indistinguishable from $T$. varians Sc elements.

$\mathbf{S c}_{2}$ elements. Sce Higgins and Varker (1982:161). The anterior process of these elements may have marked inward curvature.

\section{DISCUSSION}

The diagnosis given above is modified only slightly from that of Higgins and Varker (1982). With the recognition of T. varians morphotype III Pa elements (see below), inner lateral blade development and possession of a posterior carina can no longer be considered diagnostic of $T$. carinatus alone. However, the crestlike blade profile, larger blade denticles, the development of more nodose or bloated parapets, and the arching of the $\mathrm{Pa}$ element distinguish $T$. carinatus from other members of the genus. All elements of this species also tend to be robust but this may be an ecophenotypic character as $T$. varians elements occurring with $T$. carinatus exhibit the same tendency. Pa elements are sinistral or dextral but always with an inner or, less commonly, a more medial blade. Mirror-image pairing of elements (Class II symmetry) seems unlikely; Class IIIb symmetry must have been dominant.

$\mathrm{Pb}$ elements of $T$. carinatus differ from those of $T$. varians mainly in the thickening of the processes and the shortness of the posterior process. Some $T$. carinatus $\mathrm{Pb}$ elements approach the morphology of $T$. varians and vice versa, making specific assignment of some $\mathrm{Pb}$ elements difficult.

Higgins and Varker (1982) suggest that the $M$ element of $T$. carinatus is of "Neoprioniodus varians" form. However, the specimen they figure as the M element (pl. 19 , fig. 18) has a broad, laterally compressed cusp and a short posterior process. It is of " $N$. scitulus" form and does not belong in Taphrognathus. "Neoprioniodus sp." of 
Higgins and Varker (1982) has several characters in common with other elements of $T$. carinatus; in particular, the posterior process denticulation, the cusp, and the basal cavity are very similar to their figured $\mathrm{Pb}$ element. $\mathrm{M}$ elements identical to "Neoprioniodus sp." occur with other T. carinatus elements in the Northumberland trough. The specimen figured herein (Pl. 3, Fig. 15) differs only in the shape of the anticusp and the amount of lateral thickening of the process. This specimen is only half the size of that figured by Higgins and Varker (1982) and this variation is probably ontogenetic. M elements of " $N$. loxus" and " $N$. varians" forms, similar to those of $T$. varians, also occur with $T$. carinatus elements. These $\mathrm{M}$ elements may have been bome by some $T$. carinatus in place of the more robust $\mathrm{M}$ elements discussed above.

The Sb element figured herein (PI. 3, Fig. 12) is thinner and bears less laterally compressed denticles than the elements described by Higgins and Varker (1982). It is also smaller, and these differences are probably ontogenetic.

Taphrognathus carinatus and $T$. varians are found together in all but one sample from this study. This sample (186861; Appendix IIe) contains no $\mathrm{Sc}_{1}$ elements. Although Higgins and Varker (1982) included these elements in the apparatus of $T$. carinatus, their concept of the species also included some Pa elements herein considered to be $T$. varians. Their $\mathrm{Sc}_{1}$ elements may therefore have been associated with $T$. varians, and these elements may not belong in $T$. carinatus.

\section{Taphrognathus varians Branson and Mehl, 1941}

Plate 4, Figs. 2-15; Plate 5, Figs. 1-3

[v*] Taphrognathus varians Branson and Mehl, 1941b:182, pl. 6, figs. 27-33, 35-40 [Pa elements, morphotype I], fig. 34 [Pa element, morphotype II].

[non] Taphrognathus varians-Cooper, 1947:92, pl. 20, figs. 14-16.

[v.] Taphrognathus varians-Rexroad and Collinson, 1963:21, pl. 1, figs. 18-20 [Pa elements, morphotype I], fig. 22 [Pa element, morphotype III].

[v.] Taphrognathus-Cavusgnathus transitions Rexroad and Collinson, 1963:20, pl. 1, figs. 21, 23, 24, $25[\mathrm{~Pa}$ elements, morphotype III].

[v.] Taphrognathus varians-Rexroad and Collinson, 1965:24, pl. 1, figs. 30, 32 [Pa elements, morphotype I], fig. 31 [Pa element, morphotype I-III intermediate].

[v.] Ozarkodina sp. Rexroad and Collinson, 1965:13, pl. 1, fig. $6[\mathrm{~Pb}$ element $]$.

[v.] Hibbardella ortha Rexroad-Rexroad and Collinson, 1965:10, pl. 1, fig. 10 [Sa element]. [v.] Neoprioniodus loxus Rexroad-Rexroad and Collinson, 1965:12, pl. 1, figs. 11, 19 [M elements].

[v.] Neoprioniodus insolatus Hass-Rexroad and Collinson, 1965:11, 12, pl. 1, fig. 18.

Taphrognathus varians - Thompson and Goebel, 1969:44, 45, pl. 5, figs. 1, 3, 5, 9, 13, 14 [Pa elements, morphotype I], figs. 2, 4, 6-8, 12, 15 [Pa elements, morphotype II].

Taphrognathus sp. Thompson and Goebel, 1969:45, pl. 5, figs. 10, 11 [Pa element, morphotype II].

[vnon] Taphrognathus varians-Rhodes, Austin, and Druce, 1969:241, 242, pl. 13, figs. 4, 5.

Taphrognathus varians-Thompson and Fellows, 1970:114, 115, pl. 4, figs. 10, 15 [Pa element morphotype I].

New genus and new species Thompson and Fellows, 1970:115, pl. 4, figs. 11, 14 [Pa element, morphotype III].

Taphrognathus-Cavusgnathus transitions Austin, 1973, fig. 1.17 [Pa element, morphotype I], figs. 1.12, 1.13, 1.14, 1.15 [Pa elements, morphotype III] [cop. Rexroad and Collinson, 1963, pl. 1, figs. 18b, 24, 25, 21 b, 23].

[non] Taphrognathus varians-Austin, 1973, figs. 1.20, 1.21 [cop. Rhodes, Austin, and Druce, 1969, pl. 13, figs. 4a, 6a].

[(?)] Taphrognathus varians—Jenkins, 1974, pl. 119, fig. $5[\mathrm{~Pa}$ element, morphotype I?].

[v.] Taphrognathus varians-Austin, 1974, pl. 1, fig. 18 [Pa element, morphotype I].

[v.] Gen. nov. sp. nov. A Austin, 1974, pl. 1, figs. 11, 12 [Pa element, morphotype II].

[p] Taphrognathus varians-Pierce and Langenheim, 1974:168, 169, pl. 1, figs. 1, 5 [Pa element, morphotype III?], fig. 2 [Pa element, morphotype II] only.

[v*.] Cloghergnathus globenskii Austin in Austin and Mitchell, $1975: 48,50$, pl. 1, figs. $1-4,8-15,22,27,33[\mathrm{~Pa}$ elements, morphotype II], figs. 7, 17, 26 [Pa element, morphotype I] [figs. 3,8 cop. Austin, 1974, pl. 1, figs. $11,12]$.

[v.] Taphrognathus varians-Austin in Austin and Mitchell, 1975:53, pl. 1, figs. 5, 6, 16, 18, 19, 30 [Pa elements, morphotype I] [fig. 5 cop. Austin, 1974, pl. 1, fig. 18].

Taphrognathus varians-Nicoll and Rexroad, 1975:27, pl. 4, figs. 7-16 [Pa elements, morphotype 1].

Ozarkodina sp. Nicoll and Rexroad, 1975:26, pl. 5, figs. 4 6 [Pb elements].

Hibbardella ortha-Nicoll and Rexroad, 1975, pl. 5, figs. 7, 8 [Sa elements].

Neoprioniodus loxus-Nicoll and Rexroad, 1975, pl. 5, figs. 12-14 [M elements].

Taphrognathus varians-Ruppel, 1979, pl. 2, figs. 1-3, 10 [Pa elements, morphotype I].

Taphrognathus-Cavusgnathus transition Ruppel, 1979, pl. 2, figs. 4, 5 [Pa element, morphotype III]. 
Clydagnathus? hudsoni Metcalfe, 1980:176, pl. 13, figs. 8, 9 [Pa element, morphotype III].

[vp(?)] Cloghergnathus cravenus Metcalfe, 1981:17, pl. 11, fig. 2 only [Pa element, morphotype I].

[v.] Cloghergnathus globenskii-Metcalfe, 1981, pl. 12, figs. 1, 2 [Pa elements, morphotype II].

[v.] Taphrognathus? sp. Metcalfe, 1981:45, pl. 10, fig. 3 [Pa element, morphotype III].

[v.] Cloghergnathus rhodesi Austin-Metcalfe, 1981, pl. 10, fig. 4 [Pa element, morphotype III].

[v.] Cloghergnathus globenskii-Austin and Rhodes in Robison, 1981, text-fig. 108,3 [Pa element, morphotype 1] [cop. Austin and Mitchell, 1975, pl. 1, figs. 7, 17].

[vnon] Taphrognathus varians-Austin and Rhodes in Robison, 1981, text-fig. 108,1 [cop. Rhodes, Austin, and Druce, 1969 , pl. 13, figs. 5a-c].

[v] Taphrognathus varians-Higgins and Varker, 1982:165, pl. 18, fig. 15 [Pa element, morphotype III], fig. 16 [Pa element, morphotype I?, specimen lost].

[v.p] Cloghergnathus carinatus Higgins and Varker, 1982:160, 161 , pl. 18, figs. 4-6, 10 only [Pa elements, morphotype III].

[vp(?)] Cloghergnathus non-platform elements Higgins and Varker, 1982:161, pl. 19, fig. 4 only [Pb element] [referred to as Cloghergnathus carinatus in plate caption].

[v?] Neoprioniodus cf. acampylus Rexroad and CollinsonHiggins and Varker, 1982:164, pl. 19, fig. 16 [Sb element].

Cloghergnathus sp. A Austin and Davies, 1984, pl. 1, figs. 4, 19 [Pa elements, morphotype III].

[(?)] Taphrognathus sp. A Austin and Davies, 1984, pl. 1, fig. 3 [Pa element, morphotype III?].

[v] Taphrognathus varians-Varker and Sevastopulo, 1985, pl. 5.5, fig. 2 [Pa element, morphotype III], fig. 4 [Pa element, morphotype 1?, specimen lost] [cop. Higgins and Varker, 1982, pl. 18, figs. 15, 16].

Taphrognathus varians-Ruppel and Lemmer, 1986:34, pl. 1, figs. 1-3 [Pa elements, morphotype I], figs. 4, 5 [Pa element, morphotype III?].

Taphrognathus-Cavusgnathus transition Ruppel and Lemmer, 1986:34, pl. 1, fig. 6 [Pa element, morphotype III].

[v.] Cloghergnathus cf. globenskii-Armstrong and Purnell, 1987, pl. 2, fig. 1 [Pa element, morphotype II].

[v.] Cloghergnathus-Taphrognathus intermediate Armstrong and Purnell, 1987, pl. 2, figs. 2, 3 [Pa element, morphotype II].

[v.] Cloghergnathus sp. nov. Armstrong and Purnell, 1987, pl. 2, figs. 4, 5 [Pa elements, morphotype III].

[v?] Cloghergnathus carinalus-Armstrong and Purnell, 1987, pl. 1, fig. 17 [Pa element, morphotype III?]. [v.] Cloghergnathus sp. indet. Armstrong and Purnell, 1987, pl. 2, fig. 6 [M element], fig. 7 [Pb element], fig. 8 [? Sa element], fig. 9 [Sc element].

[v.p] Patrognathus variabilis Rhodes, Austin, and DruceArmstrong and Purnell, 1987, pl. 3, fig. 12 [Sa element].

[v.] Taphrognathus varians-Armstrong and Purnell, 1987, pl. 3, fig, $14[\mathrm{~Pa}$ element, morphotype I], fig. $15[\mathrm{~Pa}$ element, juvenile].

\section{REVISED DIAGNOSIS}

Platform elements bear an anterior blade that is free for most of its length; blade denticles subequal or increasing in size anteriorly; height of posterior end of free blade and anterior end of parapets subequal; parapets transversely ridged. Class Illb symmetry dominant, Class II rarely developed.

\section{HOLOTYPE}

University of Missouri, C578-5 (Branson and Mehl, 194 1b, pl. 6, fig. 28).

\section{TYPE HORIZON AND LOCALITY}

Keokuk shales and limestones (considered to be Salem by Rexroad and Collinson, 1963). The Troy locality about two miles east of Troy, on the Cuivre River in Lincoln County, State Highway 47, Missouri, U.S.A. (N.B. Not the Sylvan Beach locality.)

\section{MATERIAL STUDIED}

Pa elements, 372(225) [morphotype I, 13(2); morphotype II, 40(6); morphotype III, 253(32); morphotype indet., 66(185)]; Pb elements, 46(36); M elements, 52(18); Sa elements, 11(11); Sb elements, 15(5); Sc elements, 26(116); from the Lynebank and Bewcastle formations, Lower Border Group, and from the Cementstone Group. In addition, the type and figured material of Branson and Mehl (194la) and 60 unfigured specimens collected by them from the Sylvan Beach locality were studied. The collections of Rexroad and Collinson $(1963,1965)$ and Austin (in Austin and Mitchell, 1975) were also examined.

\section{DESCRIPTION}

Pa elements. Three intergrading Pa element morphotypes are recognized on the basis of anterior blade position: in morphotype I (PI. 4, Fig. 5) the blade is developed in a medial position terminating between the parapets of the platform; in morphotype II (Pl. 4, Figs. 2, 9) it is developed on the outer side of the element, with or without offset from the parapet; in morphotype III (Pl. 4, Figs. 3, 4) it is developed on the inner side with or without offset from the parapet (see Text-Fig. 7). Morphotypes II and III tend 


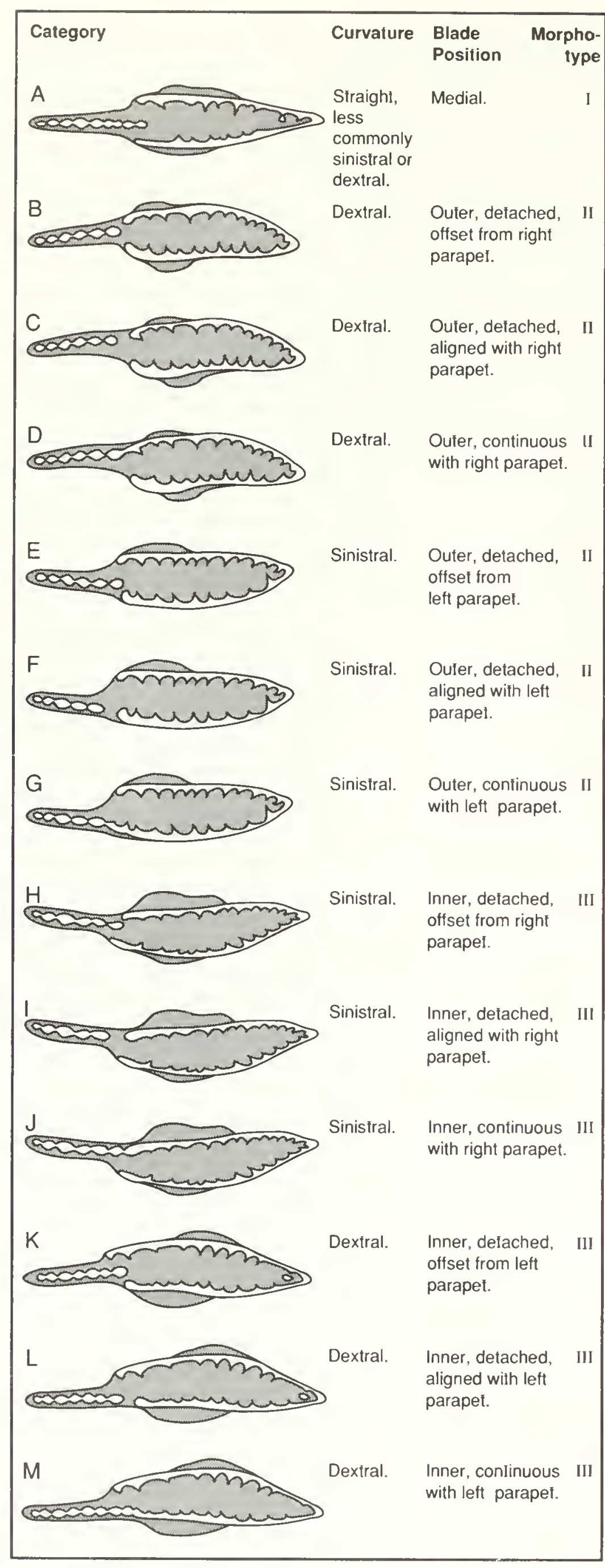

TEXT-FIG. 7. Explanation of Pa element morphotype and blade position categories of Taphrognathus varians. to develop greater lateral curvature than morphotype I. In all other respects they are similar.

At its posterior end, the anterior blade often overlaps with one or both parapets for a short distance but remains free for the greater part of its length. It bears between four and eleven denticles. These are fused apart from their tips and are generally subequal or increasing in size anteriorly apart from two or three smaller denticles often developed at the anterior end. The height of the posteriormost denticles of the free part of the blade is approximately equal to or slightly less than that of the anterior end of the nearest parapet. The blade is usually between one-quarter and two-fifths the length of the element.

The platform may be straight or sinuous but often exhibits some degree of sinistral or dextral curvature, the outer parapet being convex, the inner concave, straight, or slightly convex. The upper parts of the inner surfaces of the parapets are ornamented by weak ridges, usually becoming slightly stronger towards the posterior, often more strongly developed in larger specimens. The ridges extend part-way down the parapet surfaces, dying out towards the median trough which is generally unornamented; occasionally a weak posterior carina of a few nodes is developed. The trough may be constricted slightly at its anterior end, but is never closed, by inward curvature of one of the parapets. Irrespective of element curvature, the right parapet is often higher than the left in the anterior half of the platform. The posterior end of the platform is sharply pointed and usually terminates as a short bladelike structure, often formed as an extension of the weak carina or one of the parapets. In lateral view, the upper surface of the platform is gently convex. It has a serrated or crenulated profile, the strength of which depends on the strength of the parapet ornament. The lower surface is generally slightly concave or flat, and the overall height of the element slightly decreases posteriorly. The platform width is between one-quarter and one-fifth of its length, usually widest around the midlength of the element.

The basal cavity is lanceolate, occupying most of the lower surface. It is widest and deepest around element midlength, tapering more rapidly anteriorly than posteriorly. It continues as a groove under part of the anterior blade, and extends to a point at, or just short of, the posteriormost tip of the element. The cavity possesses a weak medial groove for its entire length and may be subsymmetrical to moderately asymmetrical.

Pb elements. See Rexroad (1957:36) under Ozarkodina compressa. T. varians $\mathrm{Pb}$ elements of this study differ from "O. compressa" sensu Rexroad (1957) in having slightly fewer denticles. Also, they have basal grooves that extend from the basal cavity but do not usually reach the distal ends of the processes. 
M elements. Sec Branson and Mehi (1941b:174) under Prioniodus varians, and Rexroad (1957:34) under Neoprioniodus loxus. M elements occur as " $N$. loxus" and " $N$. varians" morphotypes. In T. varians, as may be the case in Cavusgnathus (Rexroad, 1958a; Norby, 1976), these morphotypes differ in little other than the angle of downward deflection of the posterior process and represent extremes in the range of variation in $\mathrm{M}$ elements. Occasionally a small denticle is present on the lower anterior edge of the cusp.

Sa elements. See Rexroad (1958a:18) under Hibbardella ortha. These elements vary in the angle of divergence of the lateral processes.

Sb elements. The anterior process is straight and bears as many as 12 denticles that alternate irregularly in size. These denticles are usually subcircular in cross-section. They are suberect at the anterior end of the process and become increasingly reclined posteriorly. The process is laterally compressed, and deflected slightly inwards and either upwards or downwards relative to the posterior process. The cusp is only slightly larger than the process denticles and is reclined.

Although incomplete in all specimens, the posterior process is slightly longer than the anterior and is also slightly higher and less laterally compressed. It bears at least three laterally compressed major denticles with up to three minor denticles between each one. The denticles are discrete for most of their length and are inclined posteriorly. The small basal cavity is developed obliquely beneath the cusp. It has a small lip on the inner side and tapers to the anterior and posterior, continuing along the processes as a groove. Sb elements resemble Sc elements in general character but have a longer anterior process.

Sc elements. See Hass $(1953: 81,82)$ under Hindeodella ensis, and Clarke (1960:8) under H. tenuis. The posterior process of $T$. varians Sc elements is shorter than described by Hass (1953). The elements are variable, especially in the regularity of alternation in size of denticles on the posterior process and the degree of inward curvature of the anterior process. The posterobasal termination of some elements is abruptly downcurved beneath the steeply inclined posterior denticles.

\section{DISCUSSION}

Expansion of the generic concept of Taphrognathus to inciude $\mathrm{Pa}$ elements with a range of blade positions reduces taxonomic confusion at the genus level. Blade position, however, has also been used as a taxonomic character at the species level in Taphrognathus. Taphrognathus varians sensu Branson and Mehl (1941b), T. globenskii (Austin) (in Austin and Mitchell, 1975), and Taphrognathus sp. nov. sensu Armstrong and Purnell (1987) are differentiated primarily using blade position. In the present study, blade position was found to vary continu- ously and in discord with other characters such as curvature and carina development. Nicoll and Rexroad (1975) also noted the nonsystematic variation of these and other characters in their large collections of $T$. varians. In fact, all published work on $T$. varians documents variation in blade position (sce Table 3).

Blade position is not a sound character on which to differentiate species in Taphrognathus. In addition to its continuous variation, it varies through ontogeny (see discussion below), and is subject to environmental modification. To examine its relationship with environment, the continuum of blade position was arbitrarily divided into 13 categories (Text-Fig. 7) and the environmental distribution of these categories in the Bogside Limestone Member in Ashy Cleugh (locality 10; Appendix IIb) was analyzed (Text-Fig. 8). The Bogside Limestone Member was deposited below normal wave base in a restricted microtidal shallow-shelf setting subject to fluctuations in salinity and periodic agitation by storms (Purnell, 1989). The environmental gradient used in Text-Fig. 8 is the result of unconstrained seriation of sedimentological data for all samples of the Bogside Limestone Member from locality 10 (see Brower and Burroughs, 1982; Brower and Kile, 1988, for discussion of seriation). The resultant arrangement of samples, which reflects an environmental gradient of increasing restriction (Purnell, 1989), was then used in direct gradient analysis of $T$. varians morphotypes (see Cisne and Rabe, 1978; Springer and Bambach, 1985, for discussion of gradient analysis). Morphotype I elements (approximately equivalent to $T$. varians sensu Branson and Mehl; A in Text-Fig. 8) and morphotype II elements (approximately equivalent to Cloghergnathus glabenskii; $\mathrm{B}-\mathrm{G}$ in Text-Fig. 8) are present only in the most restricted environments. Morphotype III elements have a much broader environmental range. This distribution of morphotypes reflects increasing variability of blade position with increasing environmental restriction and supports the hypothesis that blade position is an ecophenotypic character. This trend might be a sampling artifact, the increase in observed variation reflecting the larger number of specimens recovered from the more restricted environments. However, the variation exhibited by specimens of some samples that are not high in abundance (e.g., samples 1768632 and 1411851) suggests that the trend is real.

In conclusion, blade position in T. varians is of highly dubious taxonomic significance. In the Bogside Limestone Member, specimens that would previously have been assigned to $C$. globenskii (the type species of Cloghergnathus) are ecophenotypic variants of $T$. varians sensu Branson and Mehl. The holotype of $C$. globenskii also comes from a sample that includes $T$. varians sensu Branson and Mehl, and intermediate forms. 
The three morphotypes of $T$. varians described herein differ only in blade position and serve as aids to discussion of intraspecific variation. These morphotypes are not randomly distributed. Most American $T$. varians faunas are dominated by morphotype I (e.g., Branson and Mehl, 1941b; Thompson and Goebel, 1969; Nicoll and Rexroad, 1975); the limited Irish fauna of Austin and Mitchell (1975) is dominated by morphotype II; Northumberland trough faunas are dominated by morphotype III (Armstrong and Purnell, 1987; this study). This geographical distribution might suggest that morphotypes I, II, and III represent three subspecies (sensu Mayr, 1969:41); however, the morphotypes are not geographically mutually exclusive. The separate populations show considerable overlap in their ranges of variation, and the distribution of morphotypes probably reflects different bias within the same range of variation in separate geographical areas. The holotype of $T$. varians, for example, although part of an American morphotype Idominated fauna, is intermediate between morphotypes I and II.

Taphrognathus cravenus (Metcalfe) is distinguished from $T$. varians primarily by the lateral flare or "winged" appearance of the anterior end of the right parapet. From the available material, it is unclear whether or not this character is consistently developed and of sufficient importance to maintain $T$. cravenus as a separate species.
One of the specimens figured by Metcalfe (1981, pl. 11, fig. 2) lacks this character and is included in synonymy with $T$. varians. Metcalfe (1981) also reported a single specimen of $T$. rhodesi Austin (in Austin and Mitchell, 1975). This specimen is overgrown, but appears to lack the diagnostic platform ornament of $T$. rhodesi and is probably T. varians.

The apparatus of $T$. varians is very similar to species of Cavusgnathus. Indeed, the nonplatform elements of $T$. varians, C. unicornis Youngquist and Miller, and C. altus Harris and Hollingsworth would previously have been referred to the same discrete element species. It is only because Cavusgnathus $\mathrm{Pa}$ elements do not occur with $T$. varians $\mathrm{Pa}$ elements in the Northumberland trough that the nonplatform elements of $T$. varians can be positively assigned.

Although they did not reconstruct the apparatus, Nicoll (1971) and Nicoll and Rexroad (1975) suggested that " $O$. compressa" type elements were associated with $T$. varians $\mathrm{Pa}$ elements. This is borne out by the present study. Higgins and Varker (1982) figured two $\mathrm{Pb}$ elements that they considered to belong to $T$. carinatus. One of these is probably a $T$. varians $\mathrm{Pb}$ element, but it is possible that $\mathrm{Pb}$ elements of $T$. carinatus and $T$. varians intergrade.

The $\mathrm{M}$ elements of $T$. varians vary in the angle of downward deflection of the posterior process between " $N$. loxus" and "N. varians" type elements. American authors

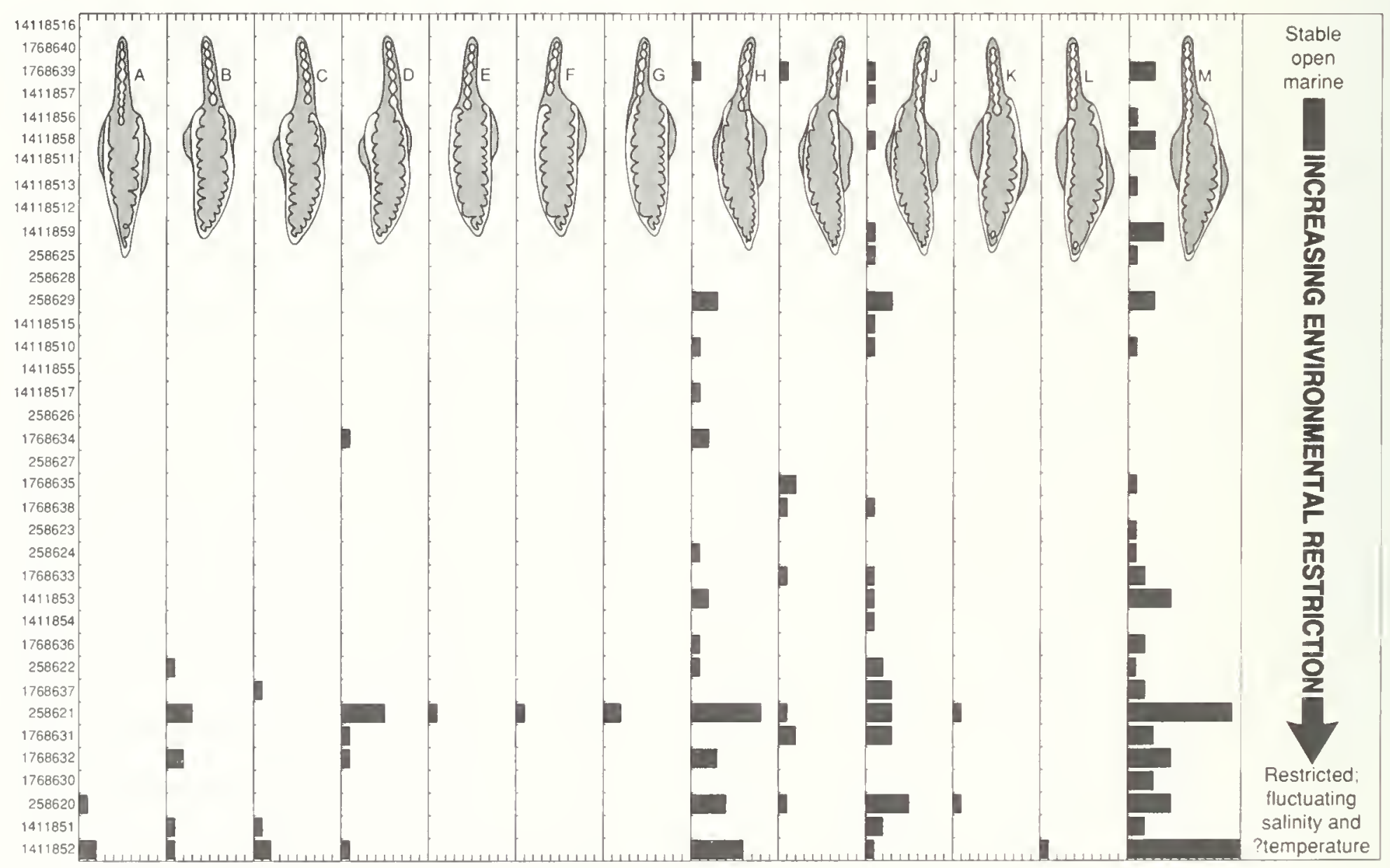

TEXT-FIG. 8. Distribution of Taphrognathus varians Pa element morphotypes along a gradient of increasing environmental restriction in the Bogside Limestone Member. Each increment of horizontal scale equals one Pa element; sample numbers at left. 
have in the past assigned their T. varians $\mathrm{M}$ elements to "N. loxus," the form with greater downward process deflection (e.g., Thompson and Gocbel, 1969; Nicoll and Rexroad, 1975). The more common form of element in the Northumberland trough is of " $N$. varians" form. This gcographic distribution corresponds to that of the $\mathrm{Pa}$ element morphotypes. Morphological intergradation and co-oceurrence of the different forms of $\mathrm{M}$ element suggest that they vary intraspecifically. $M$ elements of this type may also have been present in some $T$. carinatus (see discussion of $T$. carinatus).

Sa elements of Patrognathus capricornis (Druce) are indistinguishable from those of $T$. varians (see discussion of $P$. capricornis). The specimen figured as "Cloghergnathus? sp. indet. Sa element" by Armstrong and Purnell (1987, pl. 2, fig. 18) does not have the characteristic triangular cusp cross-section but is tentatively retained within $T$. varians.

The single specimen of Neoprioniodus ef. acampylus recovered by Higgins and Varker (1982) has a small indistinct basal cavity halfway along its length, and closely resembles $T$. varians $\mathrm{Sb}$ elements. The state of preservation of the specimen precludes a definite assignment.

\section{ONTOGENY}

During ontogeny the relative proportions of different parts of $T$. varians Pa elements change markedly (see Text-Fig. 9). The smallest specimen recovered $(0.2 \mathrm{~mm}$ in length; Text-Fig. 9a) is essentially bladelike with discrete pointed denticles and a short low platform developed as a slight expansion of the upper part of the posterior third of the element. The basal cavity is developed beneath the blade rather than the incipient platform. With increasing maturity (Text-Fig. 9b, c), the platform becomes better developed but is only weakly ornamented. At this stage, the blade is medial in position, about half the length of the element, and still bears more discrete denticles than at adult stage. The element is straight and the basal cavity extends under both the platform and the blade. Variation in blade position develops only after this stage, enabling differentiation of morphotypes I, II, and III (Text-Fig. 9d, e, f). Some immature Pa elements of $T$. varians resemble T.? transatlanticus in their small size and weak platform ornament. One figured specimen (PI. 4, Fig. 7) illustrates this resemblance. Only close examination of the platform under SEM reveals that the right parapet bears incipient ornament consisting of slight pinching and swelling rather than the unornamented surface characteristic of T? transatlanticus (see discussion of $T$ ? transallanticus). In addition to variation in blade position, increase in size and maturity is accompanied by relative shortening of the free blade to one-quarter to one-fifth of element length, development of stronger and more numerous transverse ribs on the parapets, and constriction of the anterior end of the basal cavity restricting it to the lower surface of the platform.

Published plates and the collection of Branson and Mehl (1941b) suggest that most T. varians Pa elements from the U.S.A. have an upper surface that is flat or slightly concave in its posterior half, whereas $T$. varians $\mathrm{Pa}$ elements of this study generally have convex upper platform surfaces. These differences are probably ontogenetic. Most figured T. varians from the U.S.A. and the specimens of Branson and Mehl (1941b) are over $1 \mathrm{~mm}$ in length; comparatively few specimens of this size have been found in the Northumberland trough. The few smaller specimens of $T$. varians that have been figured by American authors generally have convex upper platform surfaces (e.g., Rexroad and Collinson, 1963, pl. 1, figs. 18, 21). A few large specimens encountered in this study do, however, retain a convex platform surface as a consequence of being arched.

Text-Fig. 9 also illustrates the ontogeny of $\mathrm{Pb}$ elements. The smallest specimens (j) are short and straight; the processes have only two or three sharply pointed denticles; the basal cavity is relatively large and elongate, tapering to the ends of the processes. With increasing maturity the number of process denticles increases and the basal cavity becomes relatively smaller and more constricted.

The ontogeny of the ramiform elements is not known.

\section{Pa ELEMENT SYMMETRY}

The symmetry classification of Lane (1968) (Text-Fig. 10) provides a convenient means of discussing the pairing of Pa elements in conodont apparatuses. Lane $(1967,1968)$ discussed the phylogenetic significance of $\mathrm{Pa}$ element symmetry in some early Pennsylvanian taxa, and the differentiation of Adetognathus and Cavusgnathus on the basis of $\mathrm{Pa}$ element symmetry illustrates its potential taxonomic significance. Pa element symmetry varies both within and between genera of the Cavusgnathidae (Table 1) and may prove to be a useful character in any systematic revision of the family. Pa element symmetry also has considerable functional significance and may provide evidence in determining whether conodont apparatuses performed a grasping or filter-feeding function (Aldridge, 1987; Nicoll, 1987).

$\mathrm{Pa}$ elements that are herein considered to be T. varians have previously been assigned to symmetry Class I (Lane, 1968; Druce, 1973; Austin in Austin and Mitchell, 1975) and Class II (Austin in Austin and Mitchell, 1975). The present collection of more than $400 \mathrm{~T}$. varians $\mathrm{Pa}$ elements has enabled a detailed reassessment of their symmetry. On the basis of curvature and blade position, $\mathrm{Pa}$ elements were assigned to one of thirteen categories (Text-Fig. 7). Morphotype III elements (Text-Fig. 11; categories H-M) 


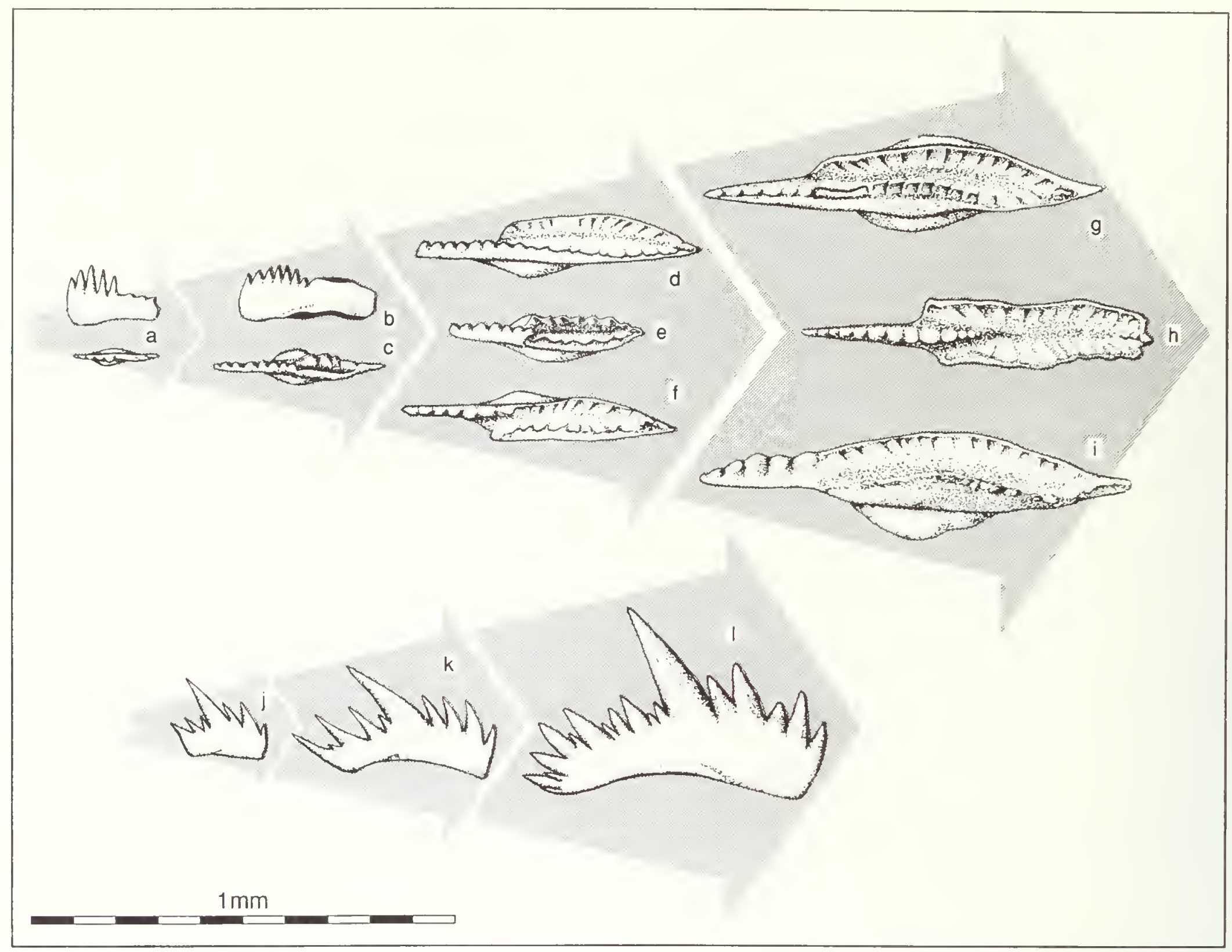

TEXT-FIG. 9. Ontogeny of $\mathrm{Pa}$ and $\mathrm{Pb}$ elements of Taphrognalhus varians. Figures based on actual specimens with broken parts restored: a) ROM 48831; b) ROM 48828; c) ROM 48830; d) NG2/267; e) TG1/569; f) ROM 48829; g) ROM 48824; h) ROM 48825; i) ROM 48822 ; j) ROM 48834; k) TG1/439; l) ROM 48832.

far outnumber morphotype I and II elements (Text-Fig. II; categories $A-G)$. This disproportionate representation and the absence of morphotype III elements in the collection of Austin and Mitchell (1975) suggests that morphotype II elements did not pair with morphotype III elements (Class IIIa symmetry). Too few morphotype II specimens were available to test this hypothesis statistically. Not enough morphotype I specimens have been recovered in this study to assess their symmetry in the Northumberland trough. $\mathrm{Pa}$ element pairing in $T$. varians morphotype III can, however, be statistically analyzed. Because it cannot be assumed that the data for each of the categories $\mathrm{H}$ to $\mathrm{M}$ are normally distributed and do not have significantly different variances, nonparametric procedures were used.

Of the 288 morphotype III Pa elements that have been categorized, 133 are sinistral $(\mathrm{H}, \mathrm{I}, \mathrm{J})$ and 155 are dextral $(\mathrm{K}, \mathrm{L}, \mathrm{M})$. Spearman's rank correlation indicates a positive relationship between the distributions of sinistral and dextral elements $(P<0.01)$ (see Purnell, 1989, for all Spearman's rank correlation data and results). This may be interpreted in two ways: either $T$. varians that bore morphotype III Pa clements existed in two forms, one with dextral and the other with sinistral $\mathrm{Pa}$ elements, which were numerically balanced and had a consistent pattern of co-occurrence; or Pa elements were paired sinistral with dextral and in the same animal. Although some cavusgnathids may have had $\mathrm{Pa}$ elements that were asymmetrically paired in terms of curvature (Rexroad, 1981), the possibility of a consistent 1:1 relationship between animals with dexiral pairing and those with sinistral seems remote.

Thus elements assigned to categories $\mathrm{H}, \mathrm{I}$, and $\mathrm{J}$ were paired with $\mathrm{K}, \mathrm{L}$, and $\mathrm{M}$ (Text-Fig. 12). $\mathrm{H}$, J, and $\mathrm{M}$ are the most common and abundant element forms (Text-Fig. 11). $\mathrm{H}$ and $\mathrm{J}$ must have paired with $\mathrm{M}$ (Text-Fig. 12), and the hypothesis that the combined distribution of $\mathrm{H}$ and $\mathrm{J}$ is unrclated to that of $\mathrm{M}$ is rejected $(P<0.01)$. A relationship between $\mathrm{J}$ and $\mathrm{M}$ is supported statistically $(P<0.001)$, but the distributions of $\mathrm{H}$ and $\mathrm{M}$ are not significantly correlated $(P>0.05)$. Given that sinistral and dextral 


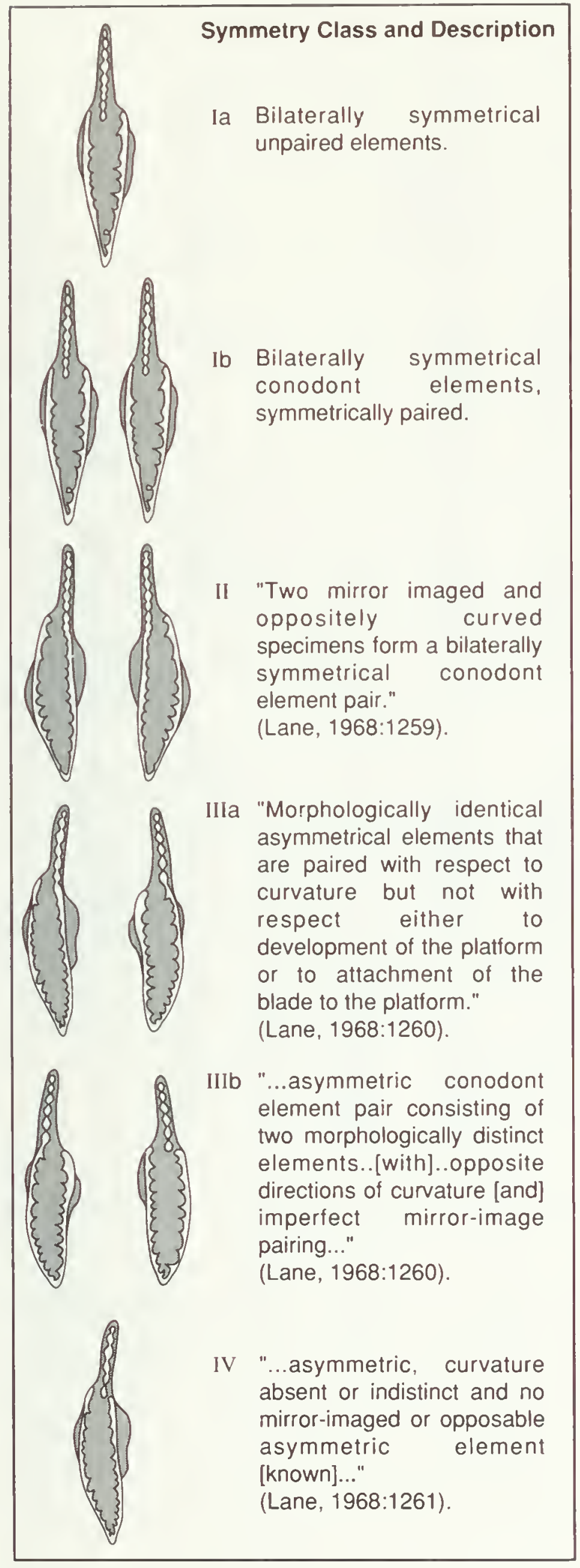

TEXT-FIG. 10. Symmetry classification of Lane (1968) illustrated by hypothetical Taphrognathus varians $\mathrm{Pa}$ element pairing. elements were paired, however, this lack of correlation is puzzling as there is little other than M type elements with which $\mathrm{H}$ forms could have paired (Text-Fig. 11). The relationship between $\mathrm{H}$ and $\mathrm{L}$ is supported statistically $(P$ $<0.05$ ) but because of the small numbers of $L$ type elements, H:L pairing was probably less common. None of the six remaining pairing permutations is supported by significant Spearman's rank correlations but, unless elements could be unpaired, at least some of them must have occurred. Only two are considered unlikely because of the rarity of both elements of the pair (Text-Fig. 12). In the majority of cases, therefore, T. varians morphotype III paired with Class IIIb symmetry. Class II symmetry (see Text-Fig. 10) is also possible but, given the variability of $\mathrm{Pa}$ elements of the species and their tendency to develop a higher right anterior parapet, was probably rare.

The 16 specimens in the Austin and Mitchell (1975) collection considered herein to be $T$. varians morphotypes I and II are inadequate for a detailed analysis of symmetry. The range of blade positions and curvature exhibited by these specimens and the morphotype II material of this study is, however, consistent with Class IIIb symmetry (Text-Fig. 13).

European collections of $T$. varians contain few morphotype I Pa elements. They may have paired together or with morphotype II or III elements (Class IIIb symmetry dominant), but the small number of known specimens precludes more rigorous analysis. Most American T. varians faunas are, however, dominated by morphotype I elements. The original collection of Branson and Mehl (1941b) includes 70 specimens from the Sylvan Beach locality. Of these, 61 elements have determinable curvature of which 30 are sinistral, 16 are dextral, and 15 are straight. These numbers suggest that sinistral-dextral and sinistral-straight pairing (Class IIIb symmetry) were most common; dextral-dextral pairing and straight-straight pairing (Class Ib symmetry) were rare (Text-Fig. 14). Again, the morphological variability of these specimens and the tendency to develop a higher right anterior parapet suggests that Class II was rarely if ever developed.

\section{Taphrognathus cf. varians}

\section{MATERIAL STUDIED}

Two Pa elements from the Cementstone Group in the Rothbury and Kielder areas.

\section{DISCUSSION}

These specimens differ from $T$. varians only in exhibiting a marked lateral bulging of the anterior end of the right parapet. Whether such specimens represent a distinct taxon or variant $T$. varians $\mathrm{Pa}$ elements is unclear. 


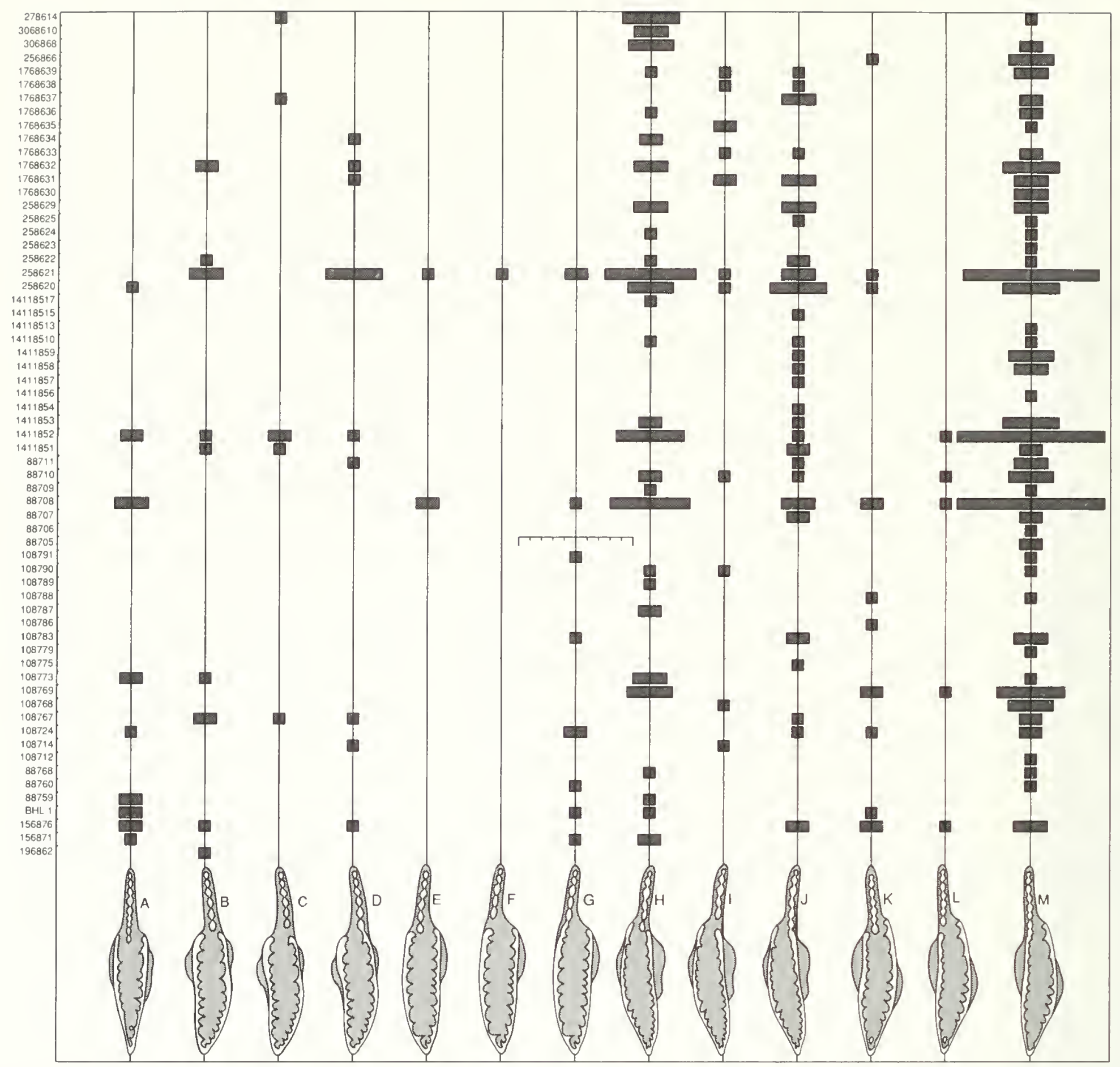

TEXT-FIG. 11. Distribution of Taphrognathus varians blade position/curvature categories in the Lower Border and Cementstone groups. Scale bar equals $10 \mathrm{~Pa}$ elements; sample numbers at left. N.B. Diagram includes only T. varians-yielding samples.

\section{Taphrognathus sp. a}

Plate 5, Figs. 5a, b

\section{MATERIAL STUDIED}

One Pa element from the Harden Member, Middle Border Group, superjacent to the Black Burn Formation.

\section{DESCRIPTION}

The apparatus of this species is unknown. The anterior blade of the Pa element is located on the left side. The blade is continuous with the outer parapet and bears four blunt denticles, the middle two of which are largest. The denticles are fixed apart from their tips and are not later- ally compressed. The blade is free for its entire length and makes up one-quarter of the length of the element. The platform is sinistral, the outer parapet convex, the inner more or less straight. The parapets have rounded crests and bear weak transverse ridges which increase slightly in strength posteriorly. The right parapet is slightly higher than the left in the anterior half. The medial trough is shallow and unornamented. It is open anteriorly and shallows towards the bluntly pointed posterior end of the element. In lateral view the element is gently arched, the platform height slightly decreasing posteriorly. Platform width is just over one-quarter of its length, widest in the anterior half. The basal cavity is lanceolate and subsymmetrical, 


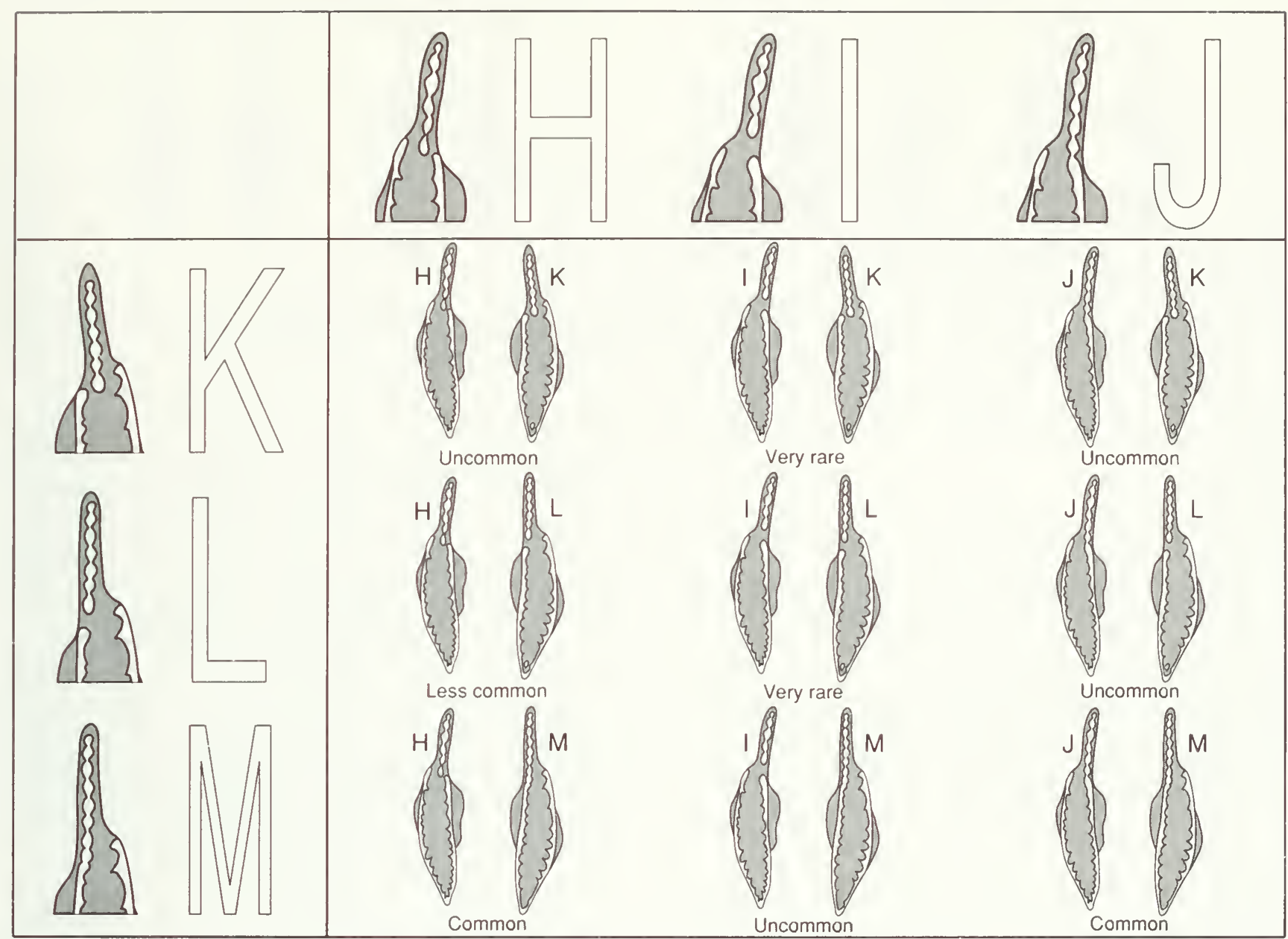

TEXT-FIG. 12. The nine possible pairings of Pa elements of Taphrognathus varians morphotype III in the present study. Relative frequency categories based on the results of Spearman's rank correlation of blade position/curvature categories.

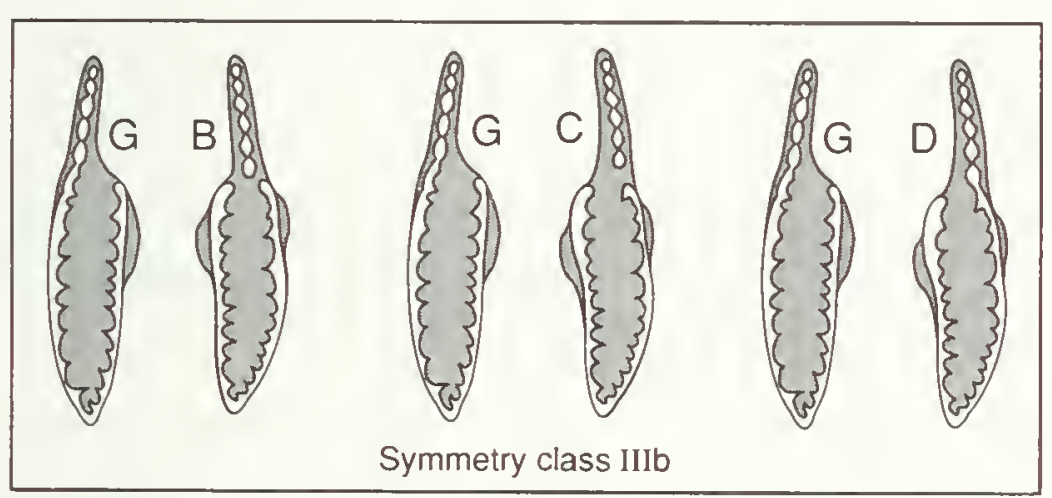

TEXT-FIG. 13. Likely Pa element pairing in Taphrognathus varians morphotype II (based on the collection of Austin and Mitchell, 1975; and this study). Letters indicate blade position/ curvature categories. and occupies most of the lower surface of the element. It is widest and deepest ai element midlength and bears a medial groove. Posteriorly the cavity tapers gently to the end of the element.

\section{DISCUSSION}

The single Pa element of Taphrognathus sp. a differs from other species of Taphrognathus chiefly in the form of the anterior blade, the roundedness of the parapet crests, and the shallowness of the medial trough. It is very similar to specimens identified as Cloghergnathus sp. A and Taphrognathus sp. B, in Marchant (1978) and Rees (1987) respectively. 


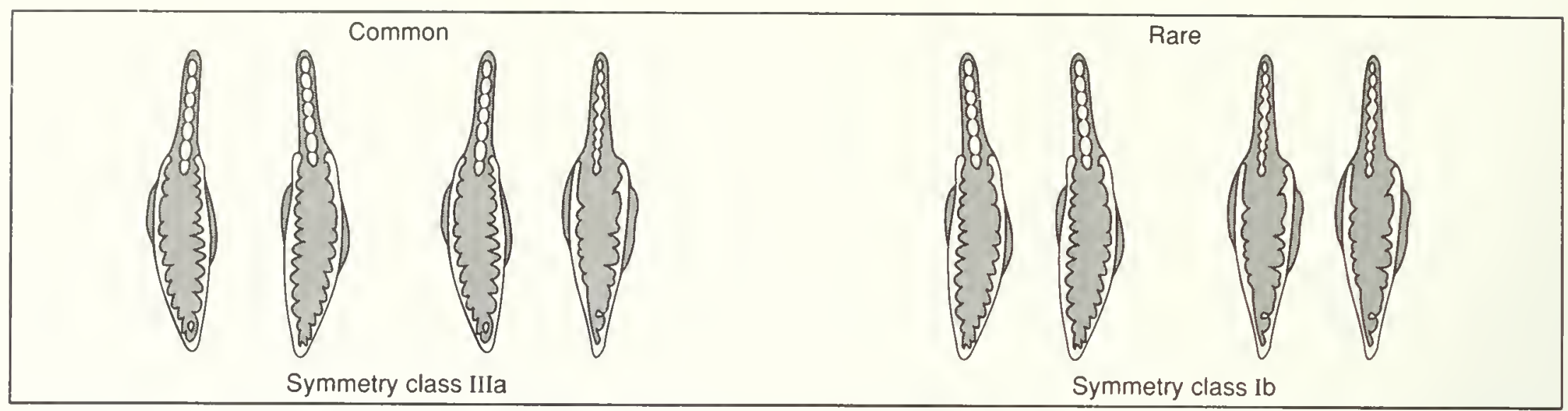

TEXT-FIG. 14. Likely Pa element pairing in Taphrognathus varians morphotype I (based on the collection of Branson and Mehl, 1941b). Symmetry classes after Lane (1968; see Text-Fig. 10).

Taphrognathus? transatlanticus (von Bitter and Austin, 1984)?

Plate 5, Figs. 4a, b

\section{MATERIAL STUDIED}

One Pa element from the Bogside Limestone Member of the Bewcastle Formation, Lower Border Group.

\section{DESCRIPTION}

See von Bitter and Austin (1984:101-106). The Pa element recovered from the Bogside Limestone differs from $T$ ? transallanticus in bearing an anterior blade that does not increase in height posteriorly.

\section{DISCUSSION}

Because of the differences from typical T.? transatlanticus noted above, and its poor state of preservation, the single specimen recovered has been assigned to $T . ?$ transatlanticus?.

In erecting $T$. transallanticus, von Bitter and Austin (1984:100) noted that neither Taphrognathus nor
Cavusgnathus were "... sufficiently broad to comfortably and unequivocally include the new species." The same is true of the revised concept of Taphrognathus. Both T. varians and $T$. carinatus bore $\mathrm{M}$ elements, whereas $T$.? transatlanticus did not. No other species of Taphrognathus has the posteriorly enlarging $\mathrm{Pa}$ element blade denticles or the unomamented parapets of $T$.? transatlanticus.

A single specimen of Taphrognathus sp. A was recovered by Davies (1980), figured by Austin and Davies (1984, pl. 1, fig. 3), and considered by von Bitter and Austin (1984) to be T. transatlanticus. This element appears to have incipient ornament on the right parapet and is probably a juvenile $T$. varians element. Similar specimens have been recovered in this study (e.g., Pl. 4, Fig. 7). Given the resemblance between juvenile $T$. varians $\mathrm{Pa}$ and $\mathrm{Pb}$ elements (Pl. 4, Figs. 7, 8, 10, 14) and their mature counterparts in T.? transallanticus, the latter species may have evolved progenetically from $T$. varians.

\section{Family Gnathodontidae Sweet, 1988}

\section{Genus Gnathodus Pander, 1856}

Grathodus Pander, 1856:33.

[non] Gnathodus Fieber, 1866.

Dryphenotus Cooper, 1939:386.

Westfalicus Moore and Sylvester-Bradley, 1957:21.

\section{DIAGNOSIS}

(After Lane, Sandberg, and Ziegler, 1980; Austin and Rhodes in Robison, 1981.) Apparatus probably seximembrate: Pa element carminiscaphate; basal cavity asymmetric, inner side bears parapet and is narrower and extends further anteriorly than the more expanded outer side. $\mathrm{Pb}$ elements angulate; $M$ elements dolabrate; Sa element alate; Sb elements bipennate; $\mathrm{Sc}$ elements bipennate. $\mathrm{Pa}$ elements paired with Class II symmetry; other elements, except the Sa, paired symmetrically.

\section{TYPE SPECIES}

Polygnathus bilineatus Roundy (1926) by subsequent designation (I.C.Z.N. opinion 1415, Tubbs, 1986).

Gnathodus cuneiformis Mehl and Thomas, 1947

Plate 5, Fig. 7

Gnathodus cuneiformis Mehl and Thomas, 1947:10, pl. 1, fig. 2. 
Gnathodus cuneiformis-Ziegler in Ziegler, 1981:123-6, Gnathodus-pl. 1, figs. 1-5 [with full synonymy].

\section{DIAGNOSIS}

Sce Lane, Sandberg, and Ziegler (1980:130).

\section{HOLOTYPE}

University of Missouri, C654-4 (Mehl and Thomas, 1947, pl. 1, fig. 2).

\section{TYPE HORIZON AND LOCALITY}

Greenish-grey and red argillaceous limestone, Fern Glen Formation, units 9-11 of Mehl and Thomas (1947); bluff of the Meramec River at Castewood, Missouri, U.S.A.

\section{MATERIAL STUDIED}

A single $\mathrm{Pa}$ element from a loose sample of the Glebe Limestone Member, Cementstone Group.

\section{DESCRIPTION}

Apparatus unknown. See Mehl and Thomas (1947:10) for $\mathrm{Pa}$ clement description.

\section{DISCUSSION}

Only the Pa elements of this species are known. The specimen recovered closely resembles the holotype, considered by Lane, Sandberg, and Ziegler (1980) to represent a younger morphotype of the species.

Gnathodus? simplicatus (Rhodes, Austin, and Druce, 1969)

Plate 5, Fig. 6

Gnathodus simplicatus Rhodes, Austin, and Druce, 1969:107, pl. 8, fig. 5; pl. 18, figs. 2-5.

\section{DIAGNOSIS}

Sce Rhodes, Austin, and Druce (1969:107).

\section{HOLOTYPE}

British Muscum, X89 (Rhodes, Austin, and Druce, 1969, pl. 18, fig. 4).

\section{TYPE HORIZON AND LOCALITY}

Sample ZLA 33 of Rhodes, Austin, and Druce (1969), North Crop, South Wales Coalfield, U.K. (precise locality details are confused in Rhodes, Austin, and Druce, 1969).

\section{MATERIAL STUDIED}

A single $\mathrm{Pa}$ element from the Harden Member, Middle Border Group, superjacent to the Black Burn Formation.

\section{DESCRIPTION}

Apparatus unknown. Sce Rhodes, Austin, and Druce (1969:107) for description of Pa elements.

\section{DISCUSSION}

See Davies (1980) for the only recent synonymy for this species. Only the Pa elements are known. The specimen recovered in this study is very similar to the holotype, but does not have the regularly sloping upper surface considered to be diagnostic by Rhodes, Austin, and Druce (1969). It is also similar to $G$. simplicatus from Ireland figured by Johnston and Higgins (1981).

According to Lane, Sandberg, and Ziegler (1980), an expanded asymmetric basal cavity and the development of an inner parapet are diagnostic of Gnathodus. The simple carminiscaphate $\mathrm{Pa}$ elements of this species should probably be referred to another genus, but without knowledge of the apparatus this new generic assignment cannot be determined.

Family Mestognathidae Austin and Rhodes in Robison, 1981

Genus Mestognathus Bischoff, 1957

Mestognathus Bischoff, 1957:36.

\section{DIAGNOSIS}

See von Bitter, Sandberg, and Orchard (1986:32).

\section{TYPE SPECIES}

Mestognathus beckmanni Bischoff, 1957, by original designation.
Mestognathus beckmanni Bischoff, 1957

Plate 5, Figs. 8, 9

Mestognathus beckmanni Bischoff, 1957:37, pl. 2, figs. 4$6,8,9$ [Pa elements].

[(?)] Ozarkodina macra Branson and Mehl-Metcalfe, 1980:173, fig. 3 (table) [Pb elements] [not figured].

[v.] Ozarkodina macra-Metcalfe, 1981, pl. 19, fig. 6 [Pb element]. 
Mestognathus beckmanni-von Bitter, Sandberg, and Orchard, 1986:35-37, pl. 1, figs. 1-8, 23; pl. 2, figs. 15,9 ; pl. 3 , figs. $1-5,9$; pl. 4 , figs. $1-5,9$; pl. 12 , figs. $1-$ 6; pl. 13, figs. 1-9; pl. 14, figs. 1-12; pl. 15, figs. 1-12; pl. 16, figs. 1-12; pl. 17, figs. 1-13; pl. 19, figs. 1-5; pl. 20 , figs. $3,6,10,12$; pl. 23, figs. 1-3; pl. 25, figs. 7-9; pl. 26, fig. 4; pl. 27, figs. 3, 4, 7 [Pa elements] [with full synonymy for Pa element].

[v.p] Cavusgnathus unicornis Youngquist and MillerArmstrong and Purnell, 1987, pl. 1, fig. 13 only $[\mathrm{Pb}$ element].

[vnon] Mestognathus beckmanni-Armstrong and Purnell, 1987, pl. 3, figs. 4, 5, 6, 7 .

\section{DIAGNOSIS}

See von Bitter, Sandberg, and Orchard (1986:37).

\section{HOLOTYPE}

Phillips University (Marburg), Bi 1957/35 (Bischoff, 1957, pl. 2, fig. 4).

\section{TYPE HORIZON AND LOCALITY}

Lower Goniatites Stufe, cu III $\alpha$, small quarry $1 \mathrm{~km}$ north of Lethmathe, immediately north of the Waldcafé, on the road between Lethmathe and Schwerte, Topographic Sheet Hohenlimburg, Germany.

\section{MATERIAL STUDIED}

$\mathrm{Pa}$ elements, 86(3); $\mathrm{Pb}$ elements, 1; from the Bogside Limestone Member of the Bewcastle Formation, Lower Border Group, and the Cementstone Group, Akenshaw Burn. Unpublished material, including $5 \mathrm{~Pb}$ elements, collected by Dr. N. J. Riley from the Craven basin was also examined.

\section{DESCRIPTION}

Pa elements. See von Bitter, Sandberg, and Orchard (1986:3-7, 36-37).

$\mathrm{Pb}$ elements. The anterior process is straight and bears eight to ten laterally compressed, slightly reclined denticles with sharp triangular tips. The denticles are all fused for more than half their length but become more fused towards the cusp; they are largest and least fused immediately anterior of the process midlength. The process is laterally thickened with a distinct rib or ridge developed below the base of the denticles, especially on the outer side. This rib thins towards the anterior end and the sharp lower edge, and extends along the long axis of the cusp. The cusp is as much as two or three times the length and width of the largest process denticles. It is strongly reclined at an angle of $150^{\circ}$ from the long axis of the anterior process and, in mature specimens, has an irregularly stepped or weakly serrated anterior edge. The serration appears to be caused by the incorporation of two or three anterior denticles into the cusp during ontogeny. The posterior process is straight and is deflected downwards at an angle of approximately $40^{\circ}$ from the anterior process. It is similar to the anterior process in terms of length, denticle size and shape, and the thin lower margin, but is less thickened and slightly lower. The posterior end is commonly missing, but the process bears as many as nine or more denticles which are increasingly reclined posteriorly. The basal cavity is narrow and elongate; it is situated beneath the cusp and does not extend along the thin lower edges of the processes, both of which bear a zone of recessive basal margin (eversion strips). White matter is developed along the growth axes of the cusp and posterior denticles especially.

\section{DISCUSSION}

von Bitter, Sandberg, and Orchard (1986) were uncertain if Mestognathus bore nonplatform elements, but did not rule out the possibility that they may have been present under optimum conditions. The present study suggests that in certain environments $M$. beckmanni bore a pair of $\mathrm{Pb}$ elements similar in form to "Ozarkodina macra." In the Northumberland trough this distinctive $\mathrm{Pb}$ element has been recovered with $M$. beckmanni $\mathrm{Pa}$ elements from the Bogside Limestone Member (Appendix IIb) and from the $3 \mathrm{~m}$ thick Tombstone Limestone, which has also yielded M. beckmanni (Armstrong and Purnell, 1987). Metcalfe (1980) recorded seven specimens of "O. macra" associated with M. beckmanni in five samples through the Embsay Limestone Member in the Craven basin. A further three specimens were reported by Metcalfe (1981), two occurring with $M$. beckmanni, one within $2 \mathrm{~m}$ of a $M$. beckmanni-yielding sample. Five specimens of "O. macra" collected by Dr. N. J. Riley from the Craven basin were all associated with $M$. beckmanni Pa elements. The rest of the fauna recovered by Metcalfe $(1980,1981)$ and Riley is made up of species of Gnalhodus and Kladognathus Rexroad with Patrognathus capricornis (Druce) and rare Polygnathus bischoffi Rhodes, Austin, and Druce. None of these conodonts bore Pb elements of "O. macra" form. In addition to this evidence of association, certain aspects of the morphology of these $\mathrm{Pb}$ elements, notably the anterior process denticles and cusp, are similar to $M$. beckmanni Pa elements (compare PI. 5, Fig. 9 with von Bitter, Sandberg, and Orchard, 1986, pl. 16, fig. 7, for example). The small basal cavity, the well-developed eversion strips, and the overall robust structure of the element are also reminiscent of $M$. beckmanni Pa elements.

Mestognathus bipluti Higgins probably also bore $\mathrm{Pb}$ elements similar to those described above. Five such $\mathrm{Pb}$ elements were assigned to Clydagnathus windsorensis (Globensky) by Plint and von Bitter (1986, table 1) and by von Bitter and Plint (1987, table 1), but were recovered from a sample which contains no Pa elements of $\mathrm{Cl}$. 
windsorensis (sample IDM-3-21). This sample does, however, contain nine $\mathrm{Pa}$ elements of $M$. bipluti and Mestognathus spp.

Mestognathus praebeckmanni Sandberg, Johnston, Orchard, and von Bitter, 1986

Plate 5, Fig. 10

Mestognathus praebeckmanni Sandberg, Johnston, Orchard, and von Bitter in von Bitter, Sandberg, and Orchard, 1986:34, 35, pl. 1, figs. 32-34; pl. 7, figs. 1-5; pl. 8, figs. 1-11; pl. 9, figs. 1-11; pl. 10, figs. 1-7, 10, 11; pl. 11, figs. 1-10 [with full synonymy].

[vp] Mestognathus beckmanni-Armstrong and Purnell, 1987, pl. 3, fig. 4 only.

\section{DIAGNOSIS}

See von Bitter, Sandberg, and Orchard (1986:35).

\section{HOLOTYPE}

United States National Muscum 257757 (von Bitter, Sandberg, and Orchard, 1986, pl. 8, figs. 1-4, 8, 10).

\section{TYPE HORIZON AND LOCALITY}

Facies de Leffe, Banc 60 of Groessens (1971, $\log 6$, section 8), route between Salet and Bioul, $8 \mathrm{~km} \mathrm{NW}$ of Dinant, Belgium.

\section{MATERIAL STUDIED}

Pa elements, 9(2) from the lower Lynebank Formation, Lower Border Group.

\section{DESCRIPTION}

Pa elements. See von Bitter, Sandberg, and Orchard (1986:3-7, 34, 35).

\section{DISCUSSION}

Many of the specimens of $M$. praebeckmanni from the Northumberland trough are transitional to M. beckmanni. with similar overall proportions and a vertical anterior left parapet termination. All other taxonomic characters are, however, typical of $M$. praebeckmanni and similar specimens were included in this species by von Bitter, Sand- berg, and Orchard (1986, pl. 10, figs. 1-7, pl. 11, figs. 1-3, $5,6)$. In general, M. praebeckmanni Pa elements from this study resemble morphotype 2 of von Bitter, Sandberg, and Orchard (1986) more closely than they do morphotype 1 or 3 .

\section{Mestognathus praebeckmanni-M. beckmanni intermediates}

Plate 5, Figs. 11, 12

Mestognathus cf. beckmanni-von Bitter, Sandberg, and Orchard, 1986:27, pl. 23, figs. 1, 2.

[vp] Mestognathus beckmanni-Armstrong and Purnell, 1987, pl. 3, fig. 6 only.

\section{MATERIAL STUDIED}

Pa elements, 8(1); from the Bogside Limestone Member of the Bewcastle Formation and the Lynebank Formation, Lower Border Group, and from the Cementstone Group, Akenshaw Bum.

\section{DISCUSSION}

The Northumberland trough represents an area where $M$. beckmanni and $M$. praebeckmanni co-existed. In such areas, von Bitter, Sandberg, and Orchard (1986) expected considerable morphologic intergradation between the two species, and this has proved to be the case in this study. One group of intermediate forms are close to M. praebeckmanni in morphology but have an anterior left parapet area, the most important criterion in differentiating species of Mestognathus, which approaches that of M. beckmanni (PI. 5, Figs. 11a, b). In most of these specimens, the anterior left parapet termination is vertical with a small anterior denticle developed. Occasionally the parapet area is more raised than that developed by $M$. praebeckmanni. Other intermediate specimens are close to $M$. beckmanni in morphology but possess a low parapet area and/or a relatively large, only slightly everted basal cavity similar to M. praebeckmanni ( $\mathrm{Pl}$. 5, Figs. 12a-c). These characteristics are also exhibited by juveniles of $M$. beckmanni; consequently, only specimens longer than $0.7 \mathrm{~mm}$ are considered intermediate. Specimens below this size are assigned to Mestognathus sp. 


\section{Genus Polygnathus Hinde, 1879}

Polygnathus Hinde, 1879:361.

Hindeodella Bassler, 1925:219.

Ctenopolygnathus Müller and Müller, 1957:1084.

\section{DIAGNOSIS}

(After Klapper and Philip, 1971; Klapper et al. in Robison, 1981.) Apparatus seximembrate; Pa elements carminiplanate (carminiscaphate in carliest species); $\mathrm{Pb}$ elements angulate; $\mathrm{M}$ elements dolabrate; Sa element alate; Sb elements digyrate; Sc element bipennate.

\section{TYPE SPECIES}

Polygnathus dubius Hinde, 1879, by subsequent designation of Miller (1889:520).

Polygnathus bischoffi Rhodes, Austin, and Druce, 1969 Plate 6, Figs. 1, 3

[v*] Polygnathus bischoffi Rhodes, Austin, and Druce, 1969:184-5, pl. 13, figs. 8-11.

Polygnathus bischoffi-Klapper in Ziegler, 1975:275-6, Polygnathus-pl. 4, fig. 5 [with synonymy].

\section{DIAGNOSIS}

See Rhodes, Austin, and Druce (1969:184).

\section{HOLOTYPE}

British Museum, X349 (Rhodes, Austin, and Druce, 1969 , pl. 13, fig. 11).

\section{TYPE HORIZON AND LOCALITY}

Sample SCC of Rhodes, Austin, and Druce (1969), South Wales Coalfield, Fall Bay, Gower, South Wales.

\section{MATERIAL STUDIED}

Pa elements, 28(6); M elements, 1(1); from the lower Lynebank Formation, Lower Border Group. In addition, the type specimens of Rhodes, Austin, and Druce (1969) and the collection of Austin and Mitchell (1975) were examined.

\section{DESCRIPTION}

Pa elements. See Rhodes, Austin, and Druce (1969: 184-5).

M elements. See Rhodes, Austin, and Druce (1969:1589) under Neoprioniodus confluens.

\section{DISCUSSION}

The $\mathrm{Pa}$ elements from the Northumberland trough have deeper anterior adcarinal troughs and larger basal cavities with more pronounced lips than the holotype and paratypes of $P$. bischoffi. These differences are almost certainly ontogenetic; no specimens that would have exceeded $0.8 \mathrm{~mm}$ in total length were found in this study, whereas the holotype is $1.32 \mathrm{~mm}$ long and both paratypes are over $1 \mathrm{~mm}$. The other figured specimen (hypotype) of Rhodes, Austin, and Druce (1969) is, however, $0.725 \mathrm{~mm}$ long and has a larger basal cavity. Austin and Mitchell (1975) recorded, but did not figure, $P$. bischoffi Pa elements from the Lower Carboniferous Shale, Northem Ireland. These elements range in length between $0.4 \mathrm{~mm}$ and $1.6 \mathrm{~mm}$; only specimens of over $0.75 \mathrm{~mm}$ develop small basal cavities.

Although the adcarinal troughs of the Pa elements from the Lower Border Group are deeper than those of larger specimens, they can still be distinguished from $\mathrm{Pa}$ elements of $P$. inornatus $\mathrm{E}$. $\mathrm{R}$. Branson in lacking the conspicuously high right anterolateral margin characteristic of the latter species.

Small Pa elements of $P$. bischoffi with their larger basal cavities resemble $\mathrm{Pa}$ elements of Pseudopolygnathus minutus Metcalfe, the holotype of which is only $0.56 \mathrm{~mm}$ long. Metcalfe (1981) suggested that $P$. bischoffi evolved from Ps. minutus, presumably peramorphically; alternatively, although the ranges of the two species are not completely concurrent (Higgins and Austin, 1985:250-1, table 6), Ps. minutus Pa elements may be immature $P$. bischoffi elements.

The single complete $\mathrm{M}$ element recovered that probably belongs to $P$. bischoffi is of "Neoprioniodus confluens" form. The posterior process is less downwardly deflected than it is in the $\mathrm{M}$ elements of $P$. mehli Thompson (see below) but, from the available material, $P$. bischoffi $\mathrm{M}$ elements cannot be distinguished from Patrognathus capricornis (Druce) M elements.

Polygnathus mehli Thompson, 1967

Plate 6, Figs. 2, 4-7, 9-11

[?] Bryantodus planus Huddle, 1934:75-6, pl. 10, fig. $8[\mathrm{~Pb}$ element].

Polygnathus mehli Thompson, 1967:47, 48, pl. 2, figs. $1-6$ [Pa elements].

[?p] Neoprioniodus confluens (Branson and Mehl)—Rhodes, 
Austin, and Druce, 1969:158, pl. 21, fig. 2 only [M element].

Polygnathus lacinatus Huddle-Higgins, 1971, pl. 1, figs. 6,8 [Pa elements].

Polygnathus mehli-Klapper in Ziegler, 1975:307-8, Polygnathus-pl. 6, fig. 4 [Pa element] [with Pa elcment synonymy].

Polygnathus lacinatus-Austin in Austin and Mitchell, 1975:52, pl. 1, figs. 28, 29, 31, 32 [Pa elements].

Polygnathus aff. P. lacinatus sensu Rhodes, Austin, and Druce-Nicoll and Druce, 1979:29, pl. 16, fig. $10[\mathrm{~Pa}$ element].

[(?)] Polygnathus lacinatus asymmetricus Rhodes, Austin, and Druce-Mctcalfe, 1981, pl. 9, fig. 5 [Pa element].

Polygnathus mehli latus Johnston and Higgins, 1981:92, 94, figs. 5.11-5.15 [Pa elements] [with partial synonymy].

"Polygnathus" mehli-Chauff, 1981, pl. 2, figs. 9, 10, 2225, 35, 36 [Pa elements].

Polygnathus mehli-Austin and Davics, 1984, pl. 1, fig. 2; pl. 2, fig. 33(?); pl. 3, figs. 10, 12 [Pa elcments].

Polygnathus lacinatus-Austin and Davies, 1984:196, text-fig. 1, pl. 2, figs. 1, 32 [Pa elements].

Polygnathus mehli latus-Varker and Sevastopulo, 1985:192, pl. 5.2, figs. 9, 10 [Pa elements].

Polygnathus mehli mehli-Varker and Sevastopulo, 1985:192, pl. 5.2, figs. 11, 12, 15, 18 [Pa element].

Polygnathus mehli-Belka, 1985, pl. 14, fig. $13[\mathrm{~Pa}$ element].

\section{DIAGNOSIS}

Pa element diagnostic, see Thompson (1967:48).

\section{HOLOTYPE}

University of Missouri, C-994-17 (Thompson, 1967, pl. 2, figs. 1, 2).

\section{TYPE HORIZON AND LOCALITY}

Pierson Formation, Unit 19; Roaring River State Park south entrance, road cut on west side of State Highway 112, locality F of Thompson (1967), Barry County, Missouri, U.S.A.

\section{MATERIAL STUDIED}

$\mathrm{Pa}$ elements, 165(14); $\mathrm{Pb}$ elements, 13(5); $\mathrm{M}$ elements, 9; Sa elements, 2(4); Sc elements, 6(2); from the Liddel Formation, Lower Border Group, and the Harden Member, Middle Border Group.

\section{DESCRIPTION}

Pa elements. See Thompson (1967:48) under P. mehli, and Rhodes, Austin, and Druce (1969:188-91) under $P$. lacinalus.

$\mathrm{Pb}$ elements. The anterior and posterior processes are subequal in length and are downcurved and slightly incurved. The anterior process bears four or five large laterally compressed, triangular denticles, free for most of their length. They are largest towards the middle of the process and increasingly reclined towards the cusp. The length of the denticles commonly exceeds the depth of the process beneath them, which exceeds them only slightly in thickness. The reclined cusp is similar in shape to the anterior denticles but is higher and wider, although sometimes only slightly so. The posterior process bears six to eight smaller less compressed and lcss discrete denticles. They are subequal in size and become increasingly reclined posteriorly. The elongate basal cavity is widest and deepest beneath the cusp, tapering to a point at or near the anterior tip of the clcment and to halfway along the posterior process.

M elements. See Rhodes, Austin, and Druce (1969:158) under Neoprioniodus confluens.

Sa element. The lateral processes diverge anteriorly at an angle of slightly less than $180^{\circ}$ in a horizontal plane, and at $90^{\circ}$ to $100^{\circ}$ in a vertical plane. They are relatively short and have a thick wedgeshaped cross-section. Process height and width are subequal towards the cusp, but width gradually decreases laterally. The processes are slightly curved downwards, with an inflection point at midlength, and each bears four discrete isolated denticles that are rounded in cross-section. The upper part of the recurved and slightly reclined cusp is also round in cross-section, but becomes more laterally compressed towards the base. The posterior process joins the cusp at a higher level than the lateral processes. It is wedgeshaped in cross-section and tapers posteriorly in height and slightly in width. The figured specimen (PI. 6, Figs. 10a, b) bears only a single small broken denticle, but the posterior process may be more denticulate. The basal cavity is shallow and everted, and tapers along the lateral processes to narrow grooves flanked by recessive basal margins. It continues along the posterior process as a slightly broader groove.

Sb elements. The Sb elements of $P$. mehli are unknown.

Sc elements. Two morphotypes occur, differing in the form of the anterior process. The more common form of process (PI. 6, Fig. 11) extends anteriorly from the cusp and is flexed outwards slightly, then gently inwards 
through about $45^{\circ}$. It is laterally compressed and bears six discrete slightly laterally compressed denticles that increase in size anteriorly. The process also thins and curves slightly downwards towards the anterior end. The other form (PI. 6, Fig. 9) is sharply deflected downwards and inwards through $90^{\circ}$. It is also laterally compressed, thinning anteriorly, and bears at least five discrete slightly incurved denticles. Apart from one or two minor denticles adjacent to the cusp, these denticles decrease in size along the process. In all other respects, these two morphotypes are similar. The recurved and slightly reclined cusp is laterally compressed towards the base but becomes more rounded in cross-section upwards. It is wider and longer than the largest process denticles. The laterally compressed posterior process is over twice the length of the anterior. It is straight and bears slightly laterally compressed reclined denticles, which alternate in size with one to three minor denticles between each major denticle. There is an overall increase in the size of the major denticles toward the posterior, the posteriormost two being considerably larger than the others. The posterobasal termination of the process is deflected downwards. The shallow elongate basal cavity is widest and deepest beneath the cusp, where a slight lip is developed on the outer side. The cavity tapers posteriorly to a groove that extends along the process to the posterobasal deflection. Anteriorly it tapers to a point halfway along the process.

\section{DISCUSSION}

The reconstruction of the apparatus of this species is based chiefly on the abundant but monospecific fauna from sample 108763. The apparatus is very similar to that of other Polygnathus species (e.g., Nicoll, 1985; Klapper and Philip, 1971).

Pa elements of $P$. mehli from the Northumberland trough vary in the width and posterior extension of the basal cavity, the degree of cavity eversion, the prominence of the recessive basal margin, the strength of the pseudokeel, the strength of the platform ornament, the degree of expansion of the posterior half of the platform, and the pointedness of the posterior tip. Polygnathus mehli mehli is distinguished from $P$. mehli latus Johnston and Higgins, in having fainter ribs, a narrower basal cavity, and a narrower platform (Johnston and Higgins, 1981). These characters were found to vary discordantly and the elements have not been assigned to subspecies. Marchant (1978) noted the variability of $P$. mehli Pa elements in his Irish material, but was also unable to recognize $P$. mehli mehli and P. mehli n. subsp. of Johnston $(1976)(=$ P. mehli latus).

M elements of $P$. mehli are similar to those of Patrognathus capricornis (Druce) but have a more strongly downwardly deflected posterior process with a broader groove along its lower surface. Sa elements resemble "Hibbardella macrodentata Thomas"; Sc elements with a downflexed incurved anterior process resemble "Hindeodella corpulenta Branson and Mehl."

\section{Family Spathognathodontidae Hass, 1959}

\section{Genus Lochriea Scott, 1942}

Lochriea Scott, 1942:298.

Paragnathodus Meischner, 1970:1173 (nom. nud.).

Paragnathodus Higgins, 1975:70.

\section{DIAGNOSIS}

(After Norby, 1976.) Apparatus at least quinquemembrate; $\mathrm{Pa}$ elements carminiscaphate with free anterior blade and large posterior basal cavity, the upper surface of which is either unornamented or bears one or two nodes. $\mathrm{Pb}$ elements angulate; $\mathrm{M}$ elements dolabrate; Sa element alate; $\mathrm{Sc}$ elements bipennate. The $\mathrm{Pb}, \mathrm{M}, \mathrm{Sc}$, and probably the $\mathrm{Pa}$ elements, were symmetrically paired.

\section{TYPE SPECIES}

Lochriea montanaensis Scott, 1942, by original designation (a subjective junior synonym of Spathognathodus commutatus Branson and Mchl, 1941c).

\section{DISCUSSION}

The generic concept followed herein is the same as that of Norby (1976) and Rexroad and Horowitz (1990). The multielement composition of the genus was reconstructed on the evidence of bedding plane assemblages (Scott, 1942; Norby, 1976).

Lochriea scotiaensis (Globensky, 1967)

Plate 6, Figs. 12a, b

[v*] Gnalhodus scotiaensis Globensky, 1967:441, pl. 58, figs. 2-7, 10, 12 [Pa elements].

[v*?] Ozarkodina acadiensis Globensky, 1967:445, pl. 55, figs. 6, 9-11, 14 [Pb elements].

[v] Neoprioniodus singularis (Branson and Mehl)-Globensky, 1967:444-5, pl. 55, figs. 23, 24 [M elements].

[v.] Gnathodus scotiaensis-von Bitter and Plint-Geberl, 1982:202, pl. 6, figs. 13-15 [Pa elements], fig. 20 [M element]. 
HOLOTYPE

University of New Brunswick, 64-F-266 (Globensky, 1967, pl. 58, figs. 2, 10).

\section{TYPE HORIZON AND LOCALITY}

Windsor Limestone, sample KD12 of Globensky (1967). On the Atlantic coast between the village of Skir Dhu and North Shore, about $330 \mathrm{~m}$ SW of Skir Dhu fisherman's wharf, Skir Dhu, Cape Breton Island, Nova Scotia, Canada.

\section{MATERIAL STUDIED}

A single Pa element from the lower Lynebank Formation, Lower Border Group, and the specimens from the Codroy Group of Newfoundland, Canada, in the collection of von Bitter and Plint-Geberl (1982).

\section{DESCRIPTION}

Pa element. Sce Globensky (1967:441) under Gnathodus scotiaensis.

M element. This element, although identified and figured by von Bitter and Plint-Geberl (1982), has not been described.

\section{DISCUSSION}

No diagnosis exists for this species. Only the Pa and M elements are known; "Ozarkodina acadiensis" may be the $\mathrm{Pb}$ element. These elements resemble the homologous clements of $L$. commutata much more closely than they do Gnathodus; Norby (1976:149) suggested that G. scotiaensis was probably a "varicty or subspecies" of $L$. commutata. Consequently, these elements are assigned to Lochriea herein.

The single $\mathrm{Pa}$ element recovered from the Northumberland trough differs from the description and the comparatively large figured specimens of Globensky
(1967:44 1, pl. 58, figs. 2-7, 10, 12; holotype is $0.74 \mathrm{~mm}$ long) chiefly in the straightness of the upper posterior part of the blade, and in bearing fewer denticles. It is, however, very similar to some specimens from the Codroy Group of SW Newfoundland (von Bitter and Plint-Geberl, 1982). Superficially, some Pa elements of $L$. scotiaensis resemble those of G.? simplicatus (Rhodes, Austin, and Druce) but the two species can be casily distinguished by the size of the basal cavity.

\section{Lochriea sp. indet.}

Platc 6, Fig. 13

\section{MATERIAL STUDIED}

$\mathrm{Pb}$ elements, (3); M elements, 10(1); mostly from the Cementstone Group, Akenshaw Burn, but also from the Cambeck Formation, Lower Border Group.

\section{DESCRIPTION}

Pb elements. Sce Higgins $(1961: 218,219)$ and Rhodes, Austin, and Druce $(1969: 198,199)$ under Subbryantodus subequalis.

M elements. See Hass (1953:88) and Rhodes, Austin, and Druce (1969:160) under Prioniodus singularis and Neoprioniodus montanaensis respectively.

\section{DISCUSSION}

Rexroad and Horowitz (1990) include a full synonymy for multielement $L$. commutata. Other species of Lochriea probably bore nonplatform elements indistinguishable from those of $L$. commutata (Norby, 1976). In the absence of associated $\mathrm{Pa}$ clements, the $\mathrm{M}$ and incomplete $\mathrm{Pb}$ elements from this study can only be assigned to Lochriea sp. indet.

\section{Family Unknown}

Genus Vogelgnathus Norby and Rexroad, 1985

Vogelgnathus Norby and Rexroad, 1985:2.

\section{DIAGNOSIS}

See Purnell and von Bitter (1992:316).

\section{TYPE SPECIES}

Spathognathodus campbelli Rexroad, 1957, by original designation.
Vogelgnathus gladiolus Purnell and von Bitter, 1992 Plate 7, Figs. 1-8

[v*] Vogelgnathus gladiolus Purnell and von Bitter, 1992:320 23, figs. 8.1-8.5 [Pa elements], figs. $8.6,8.10[\mathrm{~Pb}$ elements], figs. 8.7, 8.9 [M elements], fig. $8.8[\mathrm{Sb}$ element], fig. 8.11 [Sc element] [with full synonymy].

\section{DIAGNOSIS}

See Purnell and von Bitter (1992:320). 


\section{HOLOTYPE}

Royal Ontario Museum, ROM 48667 (Purnell and von Bitter, 1992, figs. 8.2, 8.4).

\section{TYPE HORIZON AND LOCALITY}

Bed 1.8-2.1 $\mathrm{m}$ above base of $40 \mathrm{~cm}$ shale unit exposed in quarry and waterfall section through Bogside Limestone Member, Bewcastle Formation, Lower Border Group, Ashy Cleugh, Bewcastle, Cumbria, U.K. (G.R. NY 56497700 to NY 56547695). Bed collected as sample 258624.

\section{MATERIAL STUDIED}

$\mathrm{Pa}$ elements, 127(3); Pb elements, 4; M elements, 7; Sb elements, 10(3); Sc elements, 14(17); almost all from the Bogside Limestone Member of the Bewcastle Formation, but also from the Cambeck Formation, Lower Border Group, and the Cementstone Group in Akenshaw Bum.

\section{DESCRIPTION}

See Pumell and von Bitter (1992:320-23).

\section{DISCUSSION}

Purnell and von Bitter (1992) include full description and discussion of $V$. gladiolus from the Northumberland trough.

Vogelgnathus kyphus Purnell and von Bitter, 1992

Plate 7, Figs. 9, 10, 12

$\left[v^{*}\right]$ Vogelgnathus kyphus Purnell and von Bitter, 1992:323-25, figs. 10.1-10.6 [Pa elements], fig. 10.7 [Sb element] [with full synonymy].

\section{DIAGNOSIS}

See Purncll and von Bitter (1992:323).

\section{HOLOTYPE}

Royal Ontario Museum, ROM 48677 (Purnell and von Bitter, 1992, figs. 10.3-10.5).

\section{TYPE HORIZON AND LOCALITY}

Bed 2.6-3.0 m above base of Birky Cleugh Limestone Member, Main Algal Formation, Lower Border Group, Birky Cleugh, Bewcastle, Cumbria, U.K. (G.R. NY 58997540 to NY 59017540. Bed collected as sample 88725.

\section{MATERIAL STUDIED}

Pa elements, 129(2); Sb elements, 2 (both broken during photography); 1 Sa element and 2 Sc element fragments which may belong to $V$. kyphus were also recovered.

\section{DESCRIPTION}

See Purnell and von Bitter (1992:323-25).

\section{DISCUSSION}

Purnell and von Bitter (1992) include full description and discussion of $V$. kyphus from the Northumberland trough.

\section{Vogelgnathus pesaquidi Purnell and von Bitter, 1992} Plate 7, Fig. 11

[v*] Vogelgnathus pesaquidi Purnell and von Bitter, 1992:32527, figs. 11.1-11.12 [Pa elements], figs. 11.13-11.15 [Pb elements], figs. 12.1-12.3 [M elements], figs. 12.4-12.7 [Sa elements], figs. 12.8, 12.9 [Sb elements], figs. 12.10, 12.11 [Sc elements] [with full synonymy].

\section{DIAGNOSIS}

See Purnell and von Bitter (1992:325).

\section{HOLOTYPE}

Royal Ontario Muscum, ROM 48680 (Purnell and von Bitter, 1992, fig. 11.2).

\section{TYPE HORIZON AND LOCALITY}

Beds 2.1-3.7 m above apparent base of Sanford Limestone, Miller Creek Formation, lower Windsor Group, near Windsor, Nova Scotia, Canada.

\section{MATERIAL STUDIED}

Pa elements, 23(3); Sc elements, (4); from the Bewcastle, Main Algal, and Cambeck formations, Lower Border Group; the Orroland Lodge and Barlacco Heugh formations, Orroland Group; the Southerness Formation, Cementstone Group; and the Cementstone Group of Akenshaw Bum.

\section{DESCRIPTION}

See Purnell and von Bitter (1992:325-27).

\section{DISCUSSION}

With the exception of one poorly preserved specimen from the Bewcastle Formation, Pa elements from the Northumberland trough are $V$. pesaquidi morphotype II of Purnell and von Bitter (1992).

\section{Vogelgnathus cf. pesaquidi}

Plate 8, Fig. 1

\section{MATERIAL STUDIED}

Pa elements, 4(1); from the Bewcastle Formation, Lower Border Group. 


\section{DESCRIPTION}

Apparatus unknown. Pa elements are more elongate and have less laterally compressed denticles and processes than those of $V$. pesaquidi. The basal cavity is shallower and less expanded laterally than morphotype II Pa elements of $V$. pesaquidi. The cavity is lanceolate in outline and in some specimens is not pointed posteriorly.

Order Prioniodinida Sweet, 1988

Family Prioniodinidae Bassler, 1925

\section{Genus Kladognathus Rexroad, 1958}

[non] Cladogriathus Burmeister, 1847:364.

Cladognathus Rexroad, 1957:28.

Kladognathus Rexroad, 1958a: 19.

Lambdagnathus Rexroad, 1958a:19, 20.

Cladognathodus Rexroad and Collinson, 1961:6.

Magnilaterella Rexroad and Collinson, 1963:11-14.

\section{DIAGNOSIS}

(Modified from Rexroad, 1981:11.) Platform elements not deveioped; M elements dolabrate with prominent anticusp; Sa elements alatc; Sb elements bipennate; Sc elements bipennate; Sd elements tertiopedate. The $\mathrm{S}$ elements have discrete pointed denticles.

\section{TYPE SPECIES}

Cladognathus prima Rexroad, 1957, by original designation.

\section{DISCUSSION}

The concept of Kladognathus employed herein is based on that of Rexroad (1981), Horowitz and Rexroad (1982), and Rexroad and Horowitz (1990). Apparatus reconstruction is based on the statistical studies of Horowitz and Rexroad (1982), confirming the tentative suggestion of Norby (1976).

\section{Kladognathus tenuis (Branson and Mehl, 1941a)}

Plate 8, Figs. 2, 3

[p] Prioniodus peracutus Hinde, 1900:343, pl. 10, fig. 22 only [M $\beta$ element].

Ligonodina tenuis Branson and Mehl, 1941a:170, pl. 5, figs. 13, 14 [Sc $\alpha$ elements].

Prioniodus scitulus Branson and Mehl, 1941a:173-4, pl. 5, figs. 5, 6 [ $\mathrm{M} \alpha$ elements].

Ligonodina levis Branson and Mehl, $1941 \mathrm{~b}: 185$, pl. 6, fig. 10 [Sc $\beta$ element $]$.

Lambdagnathus fragilidens Rexroad, 1958a:19, pl. 6, figs. 10-16 [Sd elements].

Kladognathus tenuis-Rexroad, 1981:13, pl. 2, figs. 19 , 21, 24-26 [Sc $\alpha$ elements], fig. 20 [Sc $\beta$ element].
Kladognathus tenuis-Rexroad and Horowitz, 1990:5056, pl. 3, figs. 28-30 [M elements], 21-24 [Sa elements], 25-27, 33 [Sb clements], 16-20 [Sc elements], 12-15 [Sd elements] [with full synonymy].

\section{DIAGNOSIS}

Sce Rexroad (1981:13).

\section{HOLOTYPE}

University of Missouri, C543-3 (Ligonodina tenuis Branson and Mehl, 1941a, pl. 5, fig. 13).

\section{TYPE HORIZON AND LOCALITY}

The Caney Shale immediately below the higher of the two conspicuous bands of concretions; steep bank of black fissile shales at the side of State Highway 48, about 6 miles south of Ada, Pontotoc County, Oklahoma, U.S.A.

\section{MATERIAL STUDIED}

Sa elements, 1; Sb elements, 1; Sc $\alpha$ elements, 3; indeterminate Sc elements, (4); from the Lower Lynebank and Cambeck formations, Lower Border Group, and the Cementstone Group of Akenshaw Burn.

\section{DESCRIPTION}

M elements. See Rhodes, Austin, and Druce (1969:1613) under Neoprioniodus peraculus and Neoprioniodus scitulus.

Sa element. See Rexroad (1958a:18) and Rhodes, Austin, and Druce (1969:113) under Hibbardella milleri and Hibbardella (Hibbardella) milleri respectively.

Sb elements. See Rexroad and Collinson (1963:14-17) under Magnilaterella robusta.

Sc $\alpha$ elements. See Branson and Mehl (1941a:170) and Rhodes, Austin, and Druce (1969:138) under Ligonodina tenuis, and Rexroad (1957:32) under L. hamata.

Sc $\beta$ elements. See Rhodes, Austin, and Druce (1969:134) under Ligonodina levis.

Sd elements. See Rexroad (1958a:19) under Lambdagnathus fragilidens.

\section{DISCUSSION}

Nicoll and Rexroad (1975) recovered "Neoprioniodus iulensis (Pander)," "Hibbardella abnormis Branson and Mehl," "Magnilaterella sp.," "Ligonodina magnilaterina 
Rhodes, Austin, and Druce," and "L. levis Branson and Mehl" from the Sanders Group of Indiana and Kentucky. Table 1 of Nicoll and Rexroad (1975) shows that these elements co-occur in approximately the same proportions relative to each other, independently of the abundance of other species, in four formations. The elements closely resemble those of Chesterian $K$. tenuis and were probably borne by Meramecian $K$. tenuis or a closely related species. This reconstruction is partly supported by the statistical analysis of Nicoll and Rexroad (1975:15).

\section{Order Unknown \\ Family Unknown}

\section{Genus "Apatognathus"}

[non] Apatognathus Branson and Mehl, 1934a:201.

\section{DISCUSSION}

Branson and Mehl (1934a) erected Apatognathus as a monotypic genus for sharply arched conodont elements with an apical cusp and two denticulate parallel or slightly divergent processes. Elements with this morphology occur in the Devonian and Lower Carboniferous but are absent from the lowest part of the Carboniferous (Scott and Collinson, 1961; Varker, 1967). The majority of conodont workers have regarded the Carboniferous forms as probable homeomorphs (e.g., Rexroad and Collinson, 1963) or morphic equivalents (Varker, 1967) which should be assigned to a different genus (e.g., Rexroad and Collinson, 1963; Klapper, 1966; Varker, 1967). The Devonian and Carboniferous apatognathid elements almost certainly belonged to markedly different apparatuses (Nicoll, 1980).

Despite the strength of the argument on both stratigraphic and morphological grounds, no genus has been formally erected to receive the Carboniferous species. Sweet (1988:115) "loosely referred" one Carboniferous apatognathid species to Hindeodus, but the reasoning behind this decision was not adequately explained. The Carboniferous apatognathid apparatus (see below) does not fit Sweet and Clark's diagnosis of the genus (in Robison, 1981) and lacks "the curious extensiform digyrate [Sb] element" that Sweet (1988:116) considered the most diagnostic feature of the apparatus of Hindeodus. Sweet (1988) conceded that his interpretation of Hindeodus was probably too broad; Carboniferous apatognathids are herein assigned to "Apalognathus" with order and family unknown.

Evidence for the apparatus of "Apatognathus" comes from a fused cluster (Austin and Rhodes, 1969) and the recurrent association of elements (summarized by von Bitter, Sandberg, and Orchard, 1986:12, table 1). Rexroad and Thompson (1979) suggested that "Apatognathus" scitulus bore an apparatus composed of elements previously described as "Spathognathodus scitulus
(Hinde)," "Ozarkodina laevipostica Rexroad and Collinson," "Apatognathus porcatus (Hinde)," and "A. scalenus Varker." Nicoll (1980) and Dean (1987) believed that the apatognathid elements of this apparatus were represented by elements of "Apatognathus porcatus" form and "Apatognathus geminus (Hinde)" form. These apparatus reconstructions, and that proposed for "A." cuspidatus Varker herein, are different from Apatognathus varians Branson and Mehl sensu Nicoll (1980), and the element notational scheme of Nicoll (1980) cannot be applied to "Apatognathus." The apatognathid elements of "Apatognathus" may have formed a symmetry transition series (Rexroad and Thompson, 1979; Sweet, 1988) and the element notation $\mathrm{Sa}, \mathrm{Sb}$, and $\mathrm{Sc}$ is used to indicate their increasing asymmetry, chiefly in terms of process incurvature (contra Nicoll, 1980; Austin et al. in Robison, 1981). This notation implies analogy rather than homology with the elements of other genera. Unlike those of the majority of conodonts, the $\mathrm{Pa}$ and $\mathrm{Pb}$ elements of "Apatognathus" represent the vicariously shared, conservative parts of the apparatus, and it is the $S$ elements that evolved more rapidly. The distributional data, however, suggest that $\mathrm{Pb}$ elements were not always developed in the apparatus (see von Bitter, Sandberg, and Orchard, 1986:12).

Rexroad and Thompson (1979) suggested that "Apalognathus varians," "Hibbardella separata (Branson and Mehl)," and "Lonchodina sp. a" sensu Rhodes, Austin, and Druce (1969) may have formed part of the "Apatognathus" apparatus. These elements were found by Druce, Rhodes, and Austin (1972) to be statistically associated in the Lower Carboniferous of the North Crop of the South Wales coalfield. However, considering the relative rarity of the "species" in this study (Druce, Rhodes, and Austin, 1972), and the lack of supporting distributional data, it is unlikely that all of these elements were borne by "Apatognathus."

N.B. Shortly after final submission of this manuscript, a new genus, Synclydognathus Rexroad and Varker, 1992, was erected to accommodate Carboniferous apatognathids. 
"Apatognathus" cuspidatus Varker, 1967

Plate 8, Figs. 4-9

[p] Apatognathus? porcata (Hinde)_Rexroad and Collinson, 1963:8, pl. 1, fig. 8 [?Sc element], figs. 10, 11 [Sb elements] only.

[p?] Ozarkodina laevipostica Rexroad and Collinson, 1963:19, pl. 1, figs. 1, 2, 4 only [Pb elements].

[p?] Spathognathodus scitulus (Hinde) - Rexroad and Collinson, 1963:20, pl. 2, figs. 14, 31 only [Pa elements].

[p] Apatognathus? porcata-Globensky, 1967:438, pl. 56, fig. 24 only [Sa element].

Apatognathus? cuspidata Varker, 1967:131, pl. 17, figs. 4, 6-8, 10 [Sb elements].

Apatognathus? librata Varker, 1967:134, pl. 18, figs. 3, 6, 8, 9, 12, 13 [Sa elements].

Apatognathus? petila Varker, 1967:135, pl. 17, fig. 11; pl. 18, figs. 7, 10, 11 [Sc clements].

[(?)] Apatognathus porcata-Thompson and Gosbel, 1969:21, pl. 2, fig. 1 [Sb element]; pl. 4, fig. 23 [Sc element].

Apalognathus petilus-Rhodes, Austin, and Druce, 1969:72, pl. 20, figs. 12-14, 17 [Sc elements].

Apalognathus cf. libratus-Rhodes, Austin, and Druce, 1969:75, pl. 20, fig. 8 [Sa element].

[p?] Spathognathodus scitulus-Rhodes, Austin, and Druce, 1969:232, pl. 8, fig. 10 only [Pa element].

[(?)] Apatognathus? cuspidatus-Reynolds, 1970:7, pl. 3, fig. 4 [Sb element].

[(?)] Apatognathus? libratus- Reynolds, 1970:7, pl. 3, fig. 9 [Sa element].

Apalognathus? petilus-Reynolds, 1970:7, pl. 3, fig. 5 [Sc element].

Apatognathus scalenus Varker-Austin and Aldridge, 1973, pl. 2, fig. 6 [Sc element].

Apatognathus petilus-Austin and Aldridge, 1973, pl. 2, fig. 9 [Sa element].

Apatognathus cuspidatus-Austin and Husri, 1974, pl. 10, figs. 8(?), 15 only [Sb elements].

[(?)] Apatognathus libratus-Austin and Husri, 1974, pl. 10, fig. 6 [?Sc element].

[(?)] Apatognathus minutus Austin and Husri, 1974:51, pl. 10, figs. 1, 2, 5, 9 [Pb elements?].

Apatognathus petilus-Austin and Husri, 1974, pl. 10, fig. 7 [Sc element].

Spathognathodus scitulus-Austin and Husri, 1974, pl. 7, fig. 10; pl. 8, fig. 6? [Pa elements].

[(?)] Apatognathus cuspidatus-Metcalfe, 1980:299, pl. 37, fig. 1 [Sb element?].

Apatognathus libratus-Metcalfe, 1980:300, pl. 37, fig. 4 [Sa element].

Spathognathodus scitulus-Metcalfe, 1980, pl. 38, fig. 7 [Pa element].

[p(?)] Apatognathus libratus-Metcalfe, 1981, pl. 13, fig. 1 only [Sa element]. [p] Apatognathus petilus-Metcalfe, 1981, pl. 13, figs. 4, 5 [Sc elements], 7 [Sc element?] only.

Apatognathus cuspidatus-Metcalfe, 1981, pl. 13, figs. 8 [Sb clement], 9 [Sb element?].

Apatognathus sp. Metcalfe, 1981, pl. 13, fig. 10 [Sc element].

Prioniodina laevipostica-Metcalfe, 1981, pl. 19, fig. 1 [Pb element].

[v.] Apatognathus cuspidatus-Higgins and Varker, 1982, pl. 19, figs. 11, 13, 19 [Sb elements].

[v?] Apatognathus libratus-_Higgins and Varker, 1982:157, pl. 19, fig. 12 [Sa element].

[v?] Spathognathodus scitulus-Higgins and Varker, 1982: 164,165 , pl. 19, fig. 14 [Pa element].

Apatognathus libratus-Austin and Davies, 1984, pl. 3, fig. 19 [Sb element].

[(?)] Apatognathus petilus-Austin and Davies, 1984, pl. 3, fig. 20 [Sc element?].

IpJ Spathognathodus scitulus-Austin and Davies, 1984, pl. 3, fig. 18 only [Pa element].

'Apatognathus' cuspidatus-Varker and Sevastopulo, 1985:196, pl. 5.4, figs. 1, 2 [Sb elements] [fig. 2 cop. Varker, 1967, pl. 17, fig. 8].

'Apatognathus' petilus-Varker and Sevastopulo, 1985: 198, pl. 5.4, figs. 3-5 [Sc elements] [figs. 4, 5 cop. Varker, 1967, pl. 18, fig. 10; pl. 17, fig. 11].

'Apatognathus' libratus-Varker and Sevastopulo, 1985:198, pl. 5.4, figs. 8-11 [Sa elements] [cop. Varker, 1967, pl. 18, figs. 6, 8, 12, 13].

[v.] 'Apatognathus' cuspidatus -Armstrong and Purnell, 1987, pl. 1, fig. 1 [Sb element].

[v.] 'Apatognathus' aff. libratus-Armstrong and Purnell, 1987, pl. 1, fig. 4 [Sa element].

[v.] 'Apatognathus' scandalensis Higgins and VarkerArmstrong and Purnell, 1987, pl. 1, fig. 3 [Sa element].

\section{REVISED DIAGNOSIS}

Apparatus at least quinquemembrate: $\mathrm{Pa}$ elements carminiscaphate with large triangular anterior denticle; $\mathrm{Pb}$ elements angulate; Sa elements alate (lacking posterior process), symmetrical, apatognathid with recurved apical cusp; Sb elements bipennate, apatognathid with large incurved reclined cusp and incurved reclined anterior process denticles; Sc elements bipennate, apatognathid with incurved reclined cusp and strongly incurved anterior process.

\section{HOLOTYPE}

University of Sheffield, Department of Geology, 28(6) BB205 (Varker, 1967, pl. 17, fig. 7).

TYPE HORIZON AND LOCALITY

Great Limestone, Borrowdale Beck, Stainmore, Cumbria, U.K. (G.R. NY 834160). 


\section{MATERIAL STUDIED}

Pa elements, 7(3); Pb elements, 1(1); Sa elements, 8(1); Sb elements, 7(3); Sc elements, 4(4); from the Bogside Limestone Member, Bewcastle Formation, and the Lynebank Formation, Lower Border Group.

\section{DESCRIPTION}

Pa elements. See Clarke (1960:21) and Rhodes, Austin, and Druce (1969:232) under Spathognathodus scitulus.

Pb elements. See Rexroad and Collinson (1963:19) under Ozarkodina laevipostica, and Rhodes, Austin, and Druce (1969:195) under Prioniodina laevipostica.

Sa elements. See Varker (1967:134) under Apatognathus? librata. Note differences in orientation terminology if elements are considered to be alate.

Sb elements. See Varker (1967:131) under Apatognathus? cuspidata.

Sc elements. See Varker (1967:135) under Apatognathus? petila.

\section{DISCUSSION}

The apparatus of "A." cuspidatus was reconstructed on the evidence of association of elements in samples 108768 and 108769 from the Lynebank Formation, Lower Border Group, and on the association of elements in previous studies. Because of the vicarious sharing of $\mathrm{Pa}$ and $\mathrm{Pb}$ elcments between "Apalognathus" species, "A." cuspidatus is the oldest available name for this species.

The range charts and element abundances of Varker (1967), Davies (1980), and Dean (1987) suggest that elements of " $A$. scalenus Varker" form may sometimes have been present in the apparatus of "A." cuspidatus, possibly representing the $\mathrm{M}$ elements. No elements of this form were found in this study.

\section{"Apatognathus"sp. a}

\section{MATERIAL STUDIED}

Sb elements, 1(1); Sc elements, 2; from the Cambeck Formation, the Bogside Limestone Member, Bewcastle Formation, and the Lynebank Formation, Lower Border Group.

\section{DESCRIPTION}

Sb elements. See Higgins and Varker (1982:158) under Apatognathus scandalensis.

Sc elements. See Higgins and Varker (1982:157) under Apatognathus asymmetricus.

\section{DISCUSSION}

The partial reconstruction of this species is based on the limited evidence of association in this study and the concurrent ranges of the elements in Ravenstonedale, Cum- bria (Higgins and Varker, 1982). This reconstruction is tentative and the species is placed in open nomenclature.

"Apatognathus"sp. indet.

Plate 8, Fig. 10

\section{MATERIAL STUDIED}

$\mathrm{Pa}$ elements, 3(3); from the Cambeck, Main Algal, and Lynebank Formations, Lower Border Group, and the Barlacco Heugh Formation, Orroland Group.

\section{DESCRIPTION}

Pa elements. See Clarke (1960:21) and Rhodes, Austin, and Druce (1969:232) under Spathognathodus scitulus.

\section{DISCUSSION}

Because of the vicarious sharing of $\mathrm{Pa}$ elements in "Apatognathus," $\mathrm{Pa}$ elements that are not associated with identifiable $S$ elements cannot be specifically assigned. Some of these elements (e.g., Pl. 8, Fig. 10) have greater posterior extension of the basal cavity than typical "Apatognathus" Pa elements.

\section{Genus Indeterminate}

Gen. a sp. a

Plate 8, Figs. 11, 12

\section{MATERIAL STUDIED}

Pa elements, 4(2); $M$ elements, 1; from the Bewcastle and Cambeck formations, Lower Border Group.

\section{DESCRIPTION}

$\mathrm{Pa}$ elements. $\mathrm{Pa}$ elements are carminate, laterally compressed, and bladelike with slight arching and lateral curvature. The only complete specimen bears 14 denticles including a minor anterior "piggy-back denticle," but the broken specimens suggest that more may be developed. The denticles are laterally compressed and elongate, fused apart from their tips. They are rather bluntly pointed in the two larger specimens recovered (including Pl. 8, Fig. 11), more sharply so in smaller specimens. Apart from the minor denticle, the denticles are highest at the anterior end, decreasing in height towards the inconspicuous cusp, increasing slightly over the basal cavity then declining to the posterior end. The anterior termination of the element is straight and almost vertical with an anterobasal angle of approximately $70^{\circ}$ to $80^{\circ}$. The basal cavity is elongate and subsymmetrical, the outer lip slightly more flared than the inner. It is widest and decpest just posterior of midlength, tapering gradually to the anterior and posterior, and bears a 
medial groove. The cavity extends to the posterior end of the element as a groove, but does not reach the posterior tip. White matter is present through the length of the four or five denticles over the basal cavity but is absent from the others.

M elements. The single $\mathrm{M}$ clement recovered is dolabrate with a long recurved cusp, the tip of which is missing. The anterobasal comer is also broken and the element may have possessed a short anticusp. The large symmetrical basal cavity occupies the whole of the lower surface of the element. It is sharply elliptical in outline, deepest and widest under the posterior margin of the cusp, and bears a medial groove. The upper posterior surface of the cavity is continuous with the posterior margin of the cusp and bears three broken reclined denticles forming the posterior process.

\section{DISCUSSION}

The generic assignment of Lower Carboniferous species that bore a simple carminate $\mathrm{Pa}$ element is problematic (see Rexroad and Thompson, 1979; Norby and Rexroad, 1985, for discussion). Pa elements similar to those described above but stratigraphically older were tentatively given the generic name Synprioniodina Bassler by Rexroad and Thompson (1979) on the basis of probable M element morphology. The probable M element of this species, however, is not of "Synprioniodina" form. When the apparatuses containing $\mathrm{Pa}$ elements of this type have been reconstructed, new generic names will be required, as was the case with Vogelgnathus Norby and Rexroad. Consequently open nomenclature has been used in preference to an obsolete or inappropriate name.

$\mathrm{Pa}$ elements of Gen. a sp. a were found in association with Cavusgnathus unicornis, Vogelgnathus gladiolus, and $V$. pesaquidi, none of which have $\mathrm{M}$ elements like that described above. The M element probably belongs to Gen. a sp. a.

\section{ACKNOWLEDGMENTS}

This research was undertaken as part of a NERC funded Ph.D. project at the University of Newcastle upon Tyne. I am indebted to Dr. Howard Armstrong (now at the University of Durham) for his supervision of all conodont-related areas of this project, and particularly for lengthy discussions regarding problems of conodont taxonomy. Dr. R. J. Aldridge (University of Leicester), Dr. R. L. Ethington (University of Missouri-Columbia), Dr. N. J. Rilcy (BGS Keyworth), Dr. J. E. Whittaker (British Museum
(Natural History)), and Dr. P. H. von Bitter (Royal Ontario Muscum) are thanked for access to and/or loan of material in their care. The assistance provided by Peter von Bitter and Joan Burke (Royal Ontario Museum) is also gratefully acknowledged. Dr. G. K. Merrill and Dr. C. A. Sandberg are thanked for their reviews of the manuscript. The manuscript was completed during tenure of a Leverhulme Trust Study Abroad Studentship at the Royal Ontario Museum. 


\section{Appendices}

\section{APPENDIX I: LOCALITY DETAILS}

1. Whitton Glebe Farm. Five metres of Glebe Limestone Member exposed in disused quarry. Grid reference: NU 051005. References: Garwood, 1931; Fowler, 1936.

2. Birky Hill. Birky Hill Limestone Member. No in situ exposure, loose blocks on site of old workings. Grid reference: NZ 048991. References: Garwood, 1931.

3. Allerdene. Old workings south of Allerdene Farm. No in situ exposure, loose blocks of Glebe Limestone Member. Grid reference: NU 025009. References: Fowler, 1936.

4. Snitter Mill. Patchy exposure of Cementstone Group in stream. Grid reference: NU 03130296. References: Fowler, 1936.

5. Snitter. Patchy exposure of Cementstone Group in Back Burn. Grid reference: NU 03050358. References: Fowler, 1936.

6. Alwinton. Barrow Scar, Alwinton Gorge on the River Coquet. Approximately $50 \mathrm{~m}$ of Cementstone Group exposed. Samples taken from south side of gorge. Grid reference: NT 904062. References: Westoll, Robson, and Green, 1955.

7. Chattlehope Bum. Patchy exposure through upper Cementstone Group. Grid reference: NT 720020. References: Cater, Briggs, and Clarkson, 1989.

8. Kielder Burn. Very poor exposure of Cementstone Group in banks of burn. Grid reference: NY 636938. References: Fowler, 1936.

9. Akenshaw Bum. Faulted and folded exposure through approximately $80 \mathrm{~m}$ of upper Cementstone Group. Grid reference: NY 605895-611897. References: Fowler, 1936.

10. Ashy Cleugh. Section through almost all of the Bewcastle Formation, Lower Border Group (locality 25 of Leeder, 1974b). Grid reference: NY 5649770058087665. References: Day, 1970; Leeder, 1974 b.

11. Antonstown Bum. Section through $7 \mathrm{~m}$ of Bogside Limestone Member, Bewcastle Formation, Lower Border Group. Grid reference: NY 56577739. References: Day, 1970.
12. Birky Cleugh. Section through uppermost Bewcastle Formation, whole of Main Algal Formation, and Lowet Antiquatonia Member of Cambeck Formation, Lower Border Group (locality 33 of Leeder, 1974b). Grid reference: NY 58857540-59437542. References: Day, 1970; Leeder, $1974 \mathrm{~b}$.

13. Whitberry Burn. Section through all but the lower part of Cambeck Formation, Lower Border Group. Grid reference: NY 52207403-52027407. References: Day, 1970.

14. Ellery Sike. Section through lower Lynebank Formation, Lower Border Group (locality 21 of Leeder, 1974b). Grid reference: NY 54337584-54507575. References: Day, 1970; Leeder, $1974 b$.

15. Bothrigg Bum. Section through lower Lynebank Formation, Lower Border Group (locality 22 of Leeder, 1974b). Grid reference: NY 54587591-54807598. References: Day, 1970; Leeder, 1974 b.

16. River Black Lyne SE of Holmhead Farm. a) Common Flat Limestone Member, Lynebank Formation. b) Section through upper Lynebank Formation and Bogside Limestone Member, Bewcastle Formation, Lower Border Group. Grid references: a) NY 54377851; b) NY 54167822-54117821. References: Day, 1970.

17. Harden Bum. Patchy exposure through Liddel Formation, Lower Border Group, and Harden Member, Middle Border Group (locality 15 of Leeder, 1974b). Grid reference: NY 51709070-52149015. References: Leeder, 1974b.

18. Black Burn. Patchy exposure through possible Amton Fell Formation?, Lower Border Group (locality 11 of Leeder, 1972, 1974b). Grid reference: NY 4787888048768869. References: Leeder, 1972, 1974 b.

19. Black Burn. Folded and faulted section through Black Burn Formation, Lower Border Group, and Harden Member, Middle Border Group (localities 7, 8, and 9 of Leeder, 1974b). References: Leeder, 1974b.

20. Black Pool, Tweeden Burn. Uppermost exposed limestone of the Liddel Formation, Lower Border Group (part of locality 18 of Leeder, 1974b). Grid reference: NY 48968643. References: Leeder, 1974b. 
21. Ettleton Sike. Section through lower Arnton Fell Formation, Lower Border Group (locality 12 of Leeder, 1974b). Grid reference: NY 47108640. References: Leeder, $1974 b$.

22. West of Drum, near Kirkbean. Basal Cementstonc Formation, Cementstone Group; patchy exposure in stream. Grid reference: NX 976612. References: Craig, 1956.

23. South of Brickhouse near Kirkbean. Basal Cementstone Formation, Cementstone Group; patchy exposure in stream. Grid reference: NX 979601. References: Craig, 1956.

24. Southerness Lighthouse. Basal beds of Gillfoot Formation, Cementstone Group. Grid reference: NX 978542. References: Craig, 1956.
25. Southerness Foreshore. Folded section through whole of Southemess Formation, Cementstone Group. Grid reference: NX 971521. References: Craig, 1956.

26. Portling outlier. Conglomerates, sandstone, and shales of Cementstone Group. Grid reference: NX 882535. References: Deegan, 1973.

27. Rerrick outlier, below Orroland. Section through Orroland Lodge and Barlacco Heugh formations, Orroland Group. Grid refercnce: NX 778463. References: Deegan, 1973. 


\section{APPENDIX II: CONODONT ELEMENTS \\ RECOVERED}

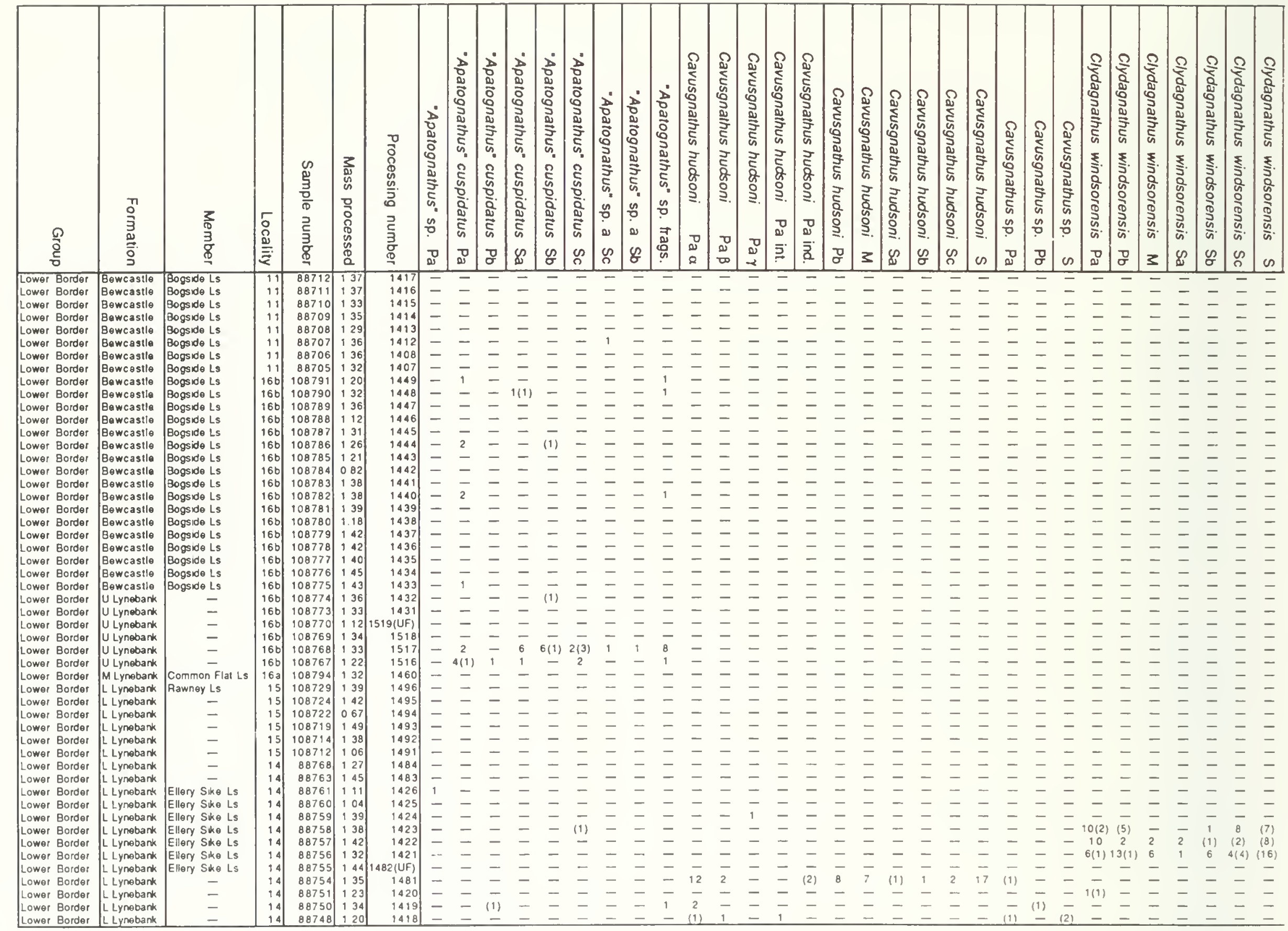

APPENDIX IIa. Conodont elements recovered from the Lynebank Formation and the Bogside Limestone Member, Bewcastle Formation, localities 11, 14-16. UF residue not completely picked; “ juvenile elements; † juvenile cavusgnathid; cavusgnathid; * includes 9 immature elements; r rare. 


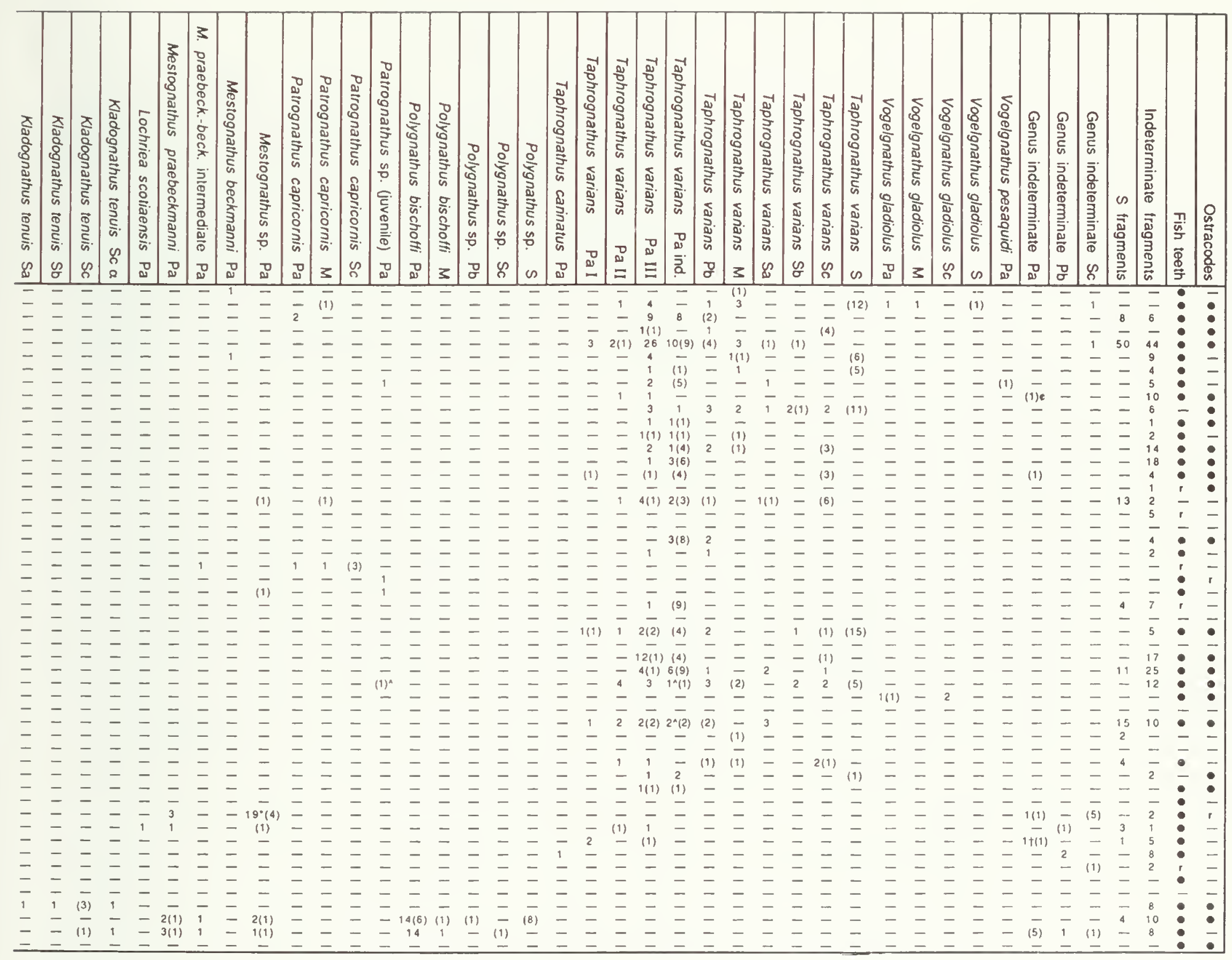




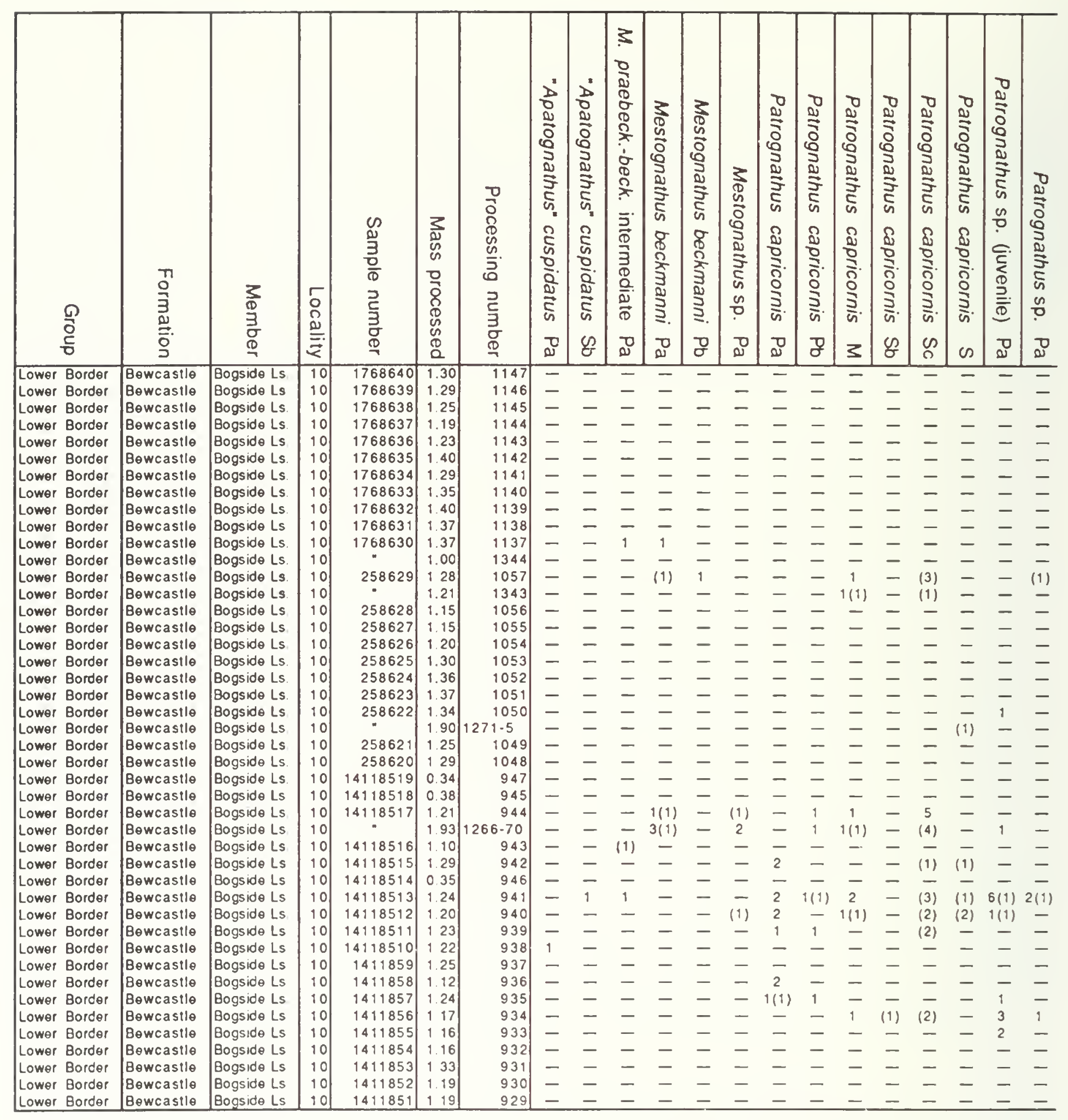

APPENDIX IIb. Conodont elements recovered from the Bogside Limestone Member, Bewcastle Formation, locality 10. 


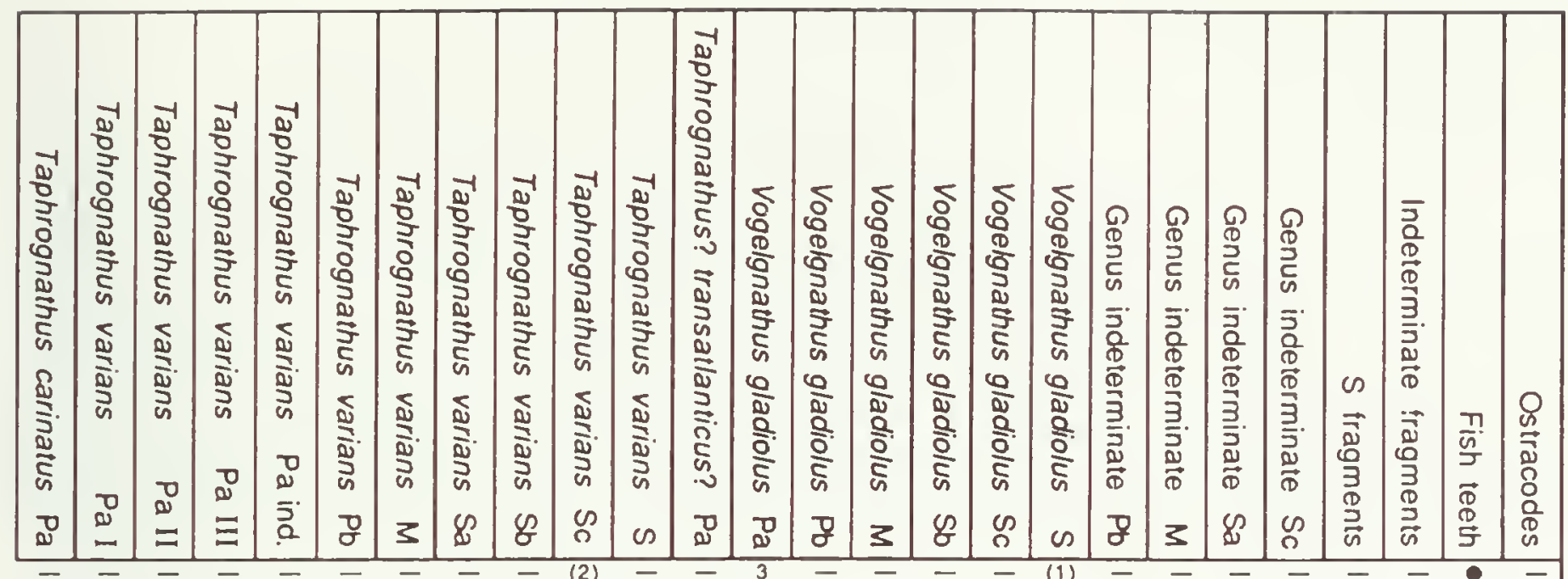

---6 (3) $-2--(8)--11--1$ (1) - - - - -1

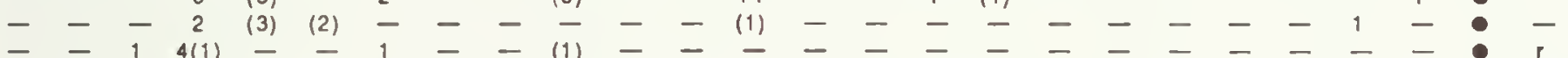

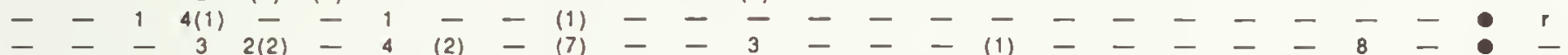

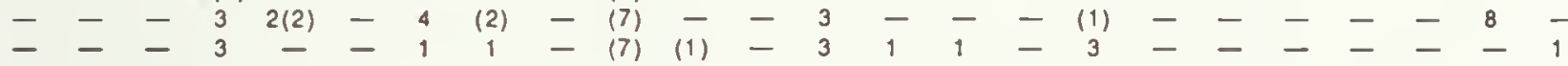

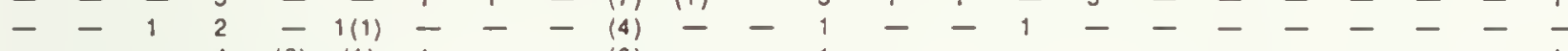

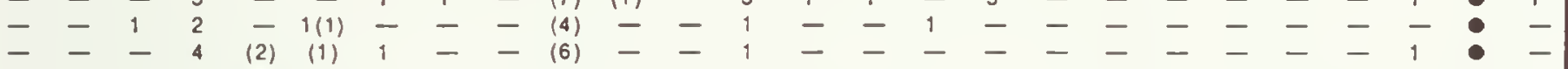

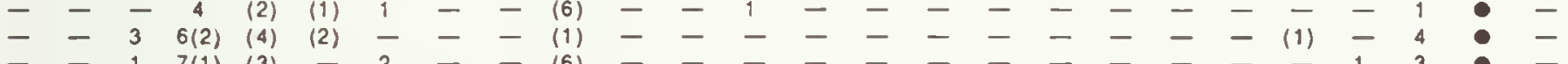

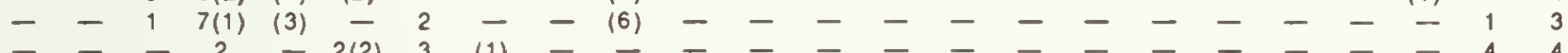

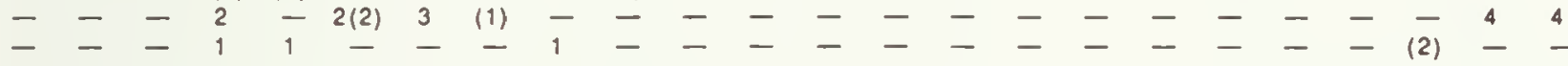

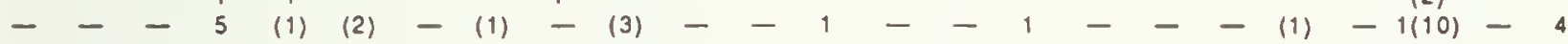

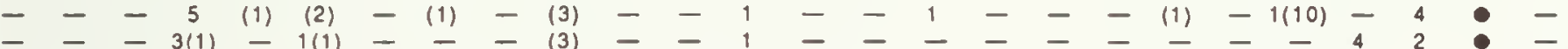

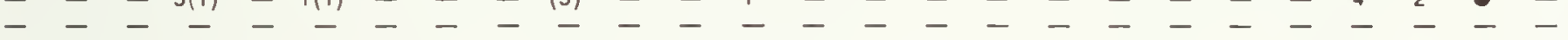

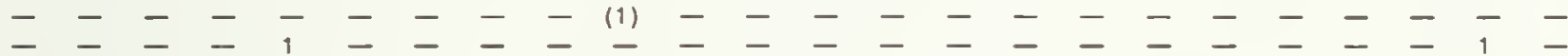

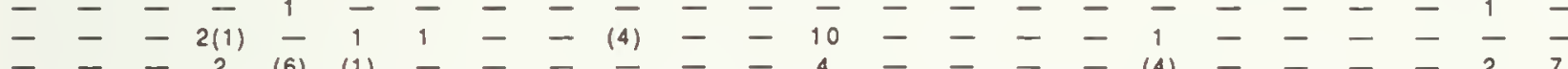

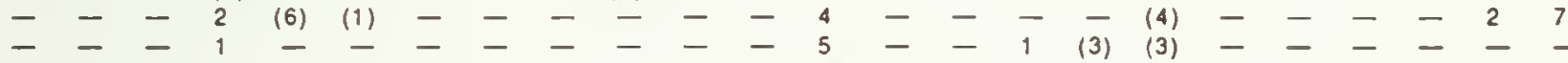

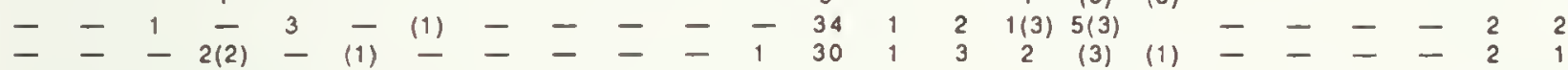

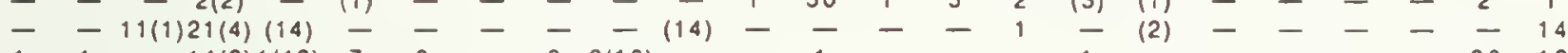

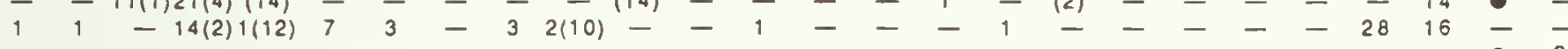

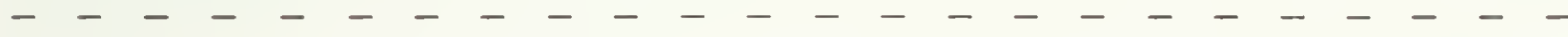

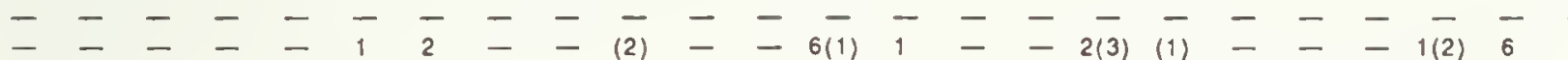

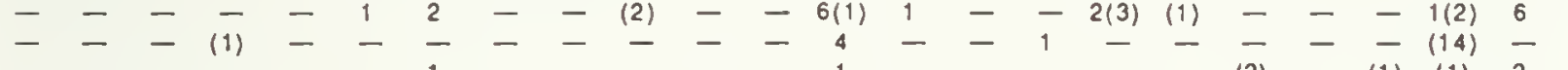

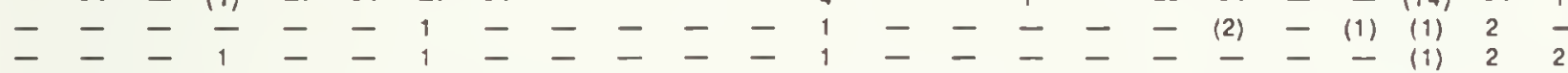

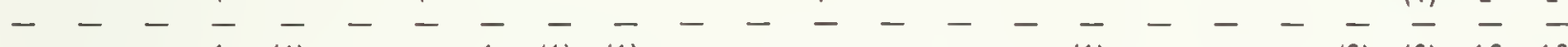

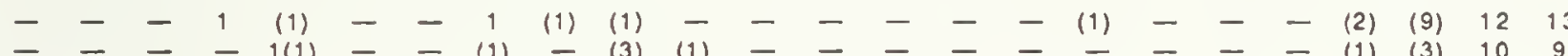

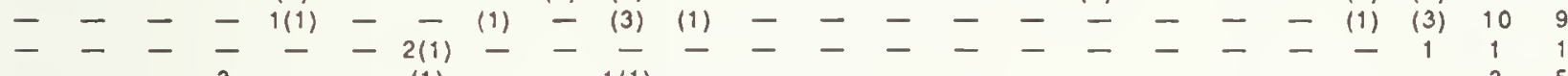

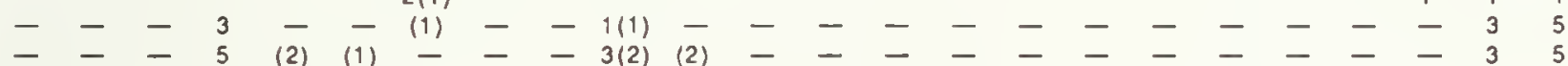

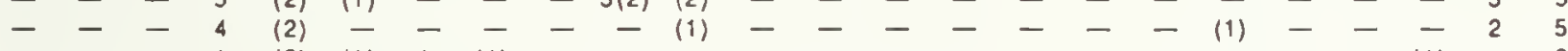

$\overline{-}= \pm 1$ (2) (1) $\begin{gathered}1 \\ \overline{-}\end{gathered}$

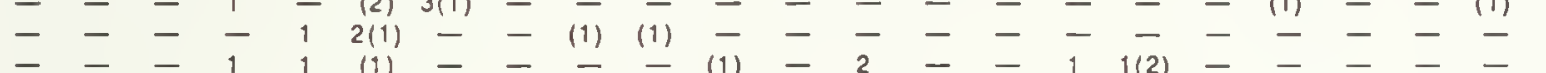

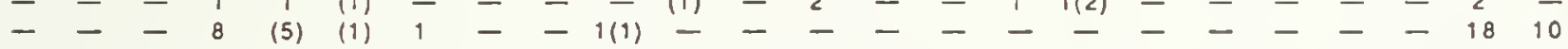

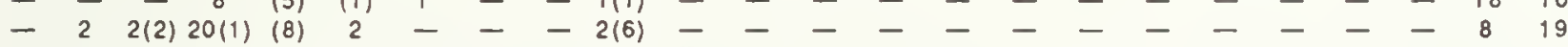




\begin{tabular}{|c|c|c|c|c|c|c|c|c|c|c|c|c|c|c|c|c|c|c|c|c|c|c|c|c|c|}
\hline 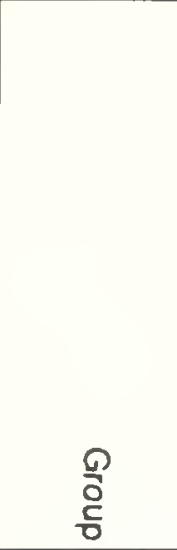 & $\begin{array}{l}\text { T1 } \\
\stackrel{0}{3} \\
\text { 3. } \\
\stackrel{0}{0} .\end{array}$ & $\begin{array}{l}\frac{3}{\Phi} \\
\frac{1}{3} \\
0 \\
0 \\
\end{array}$ & 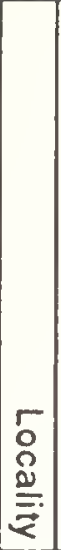 & 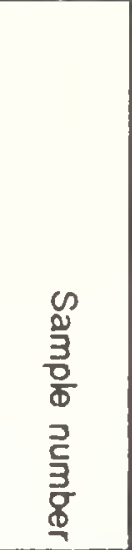 & 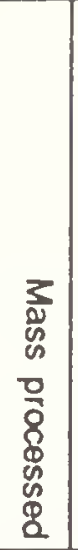 & 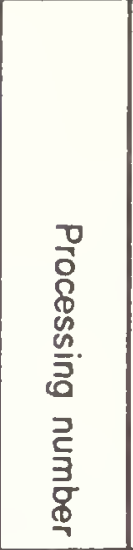 & 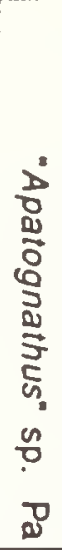 & $\begin{array}{l}\frac{D}{0} \\
0 \\
0 \\
0 \\
0 \\
0 \\
\frac{5}{5} \\
5 \\
5 \\
\infty \\
0 \\
0 \\
8 \\
8\end{array}$ & 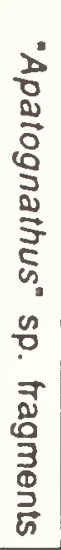 & 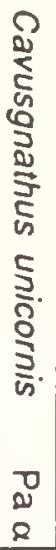 & 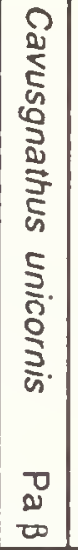 & 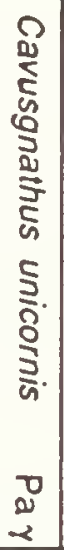 & 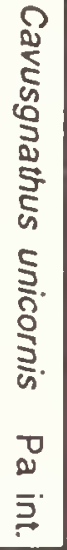 & 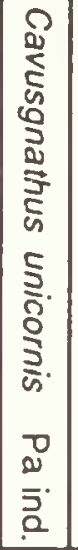 & 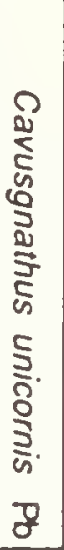 & 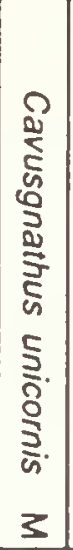 & 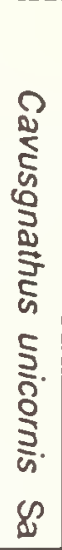 & 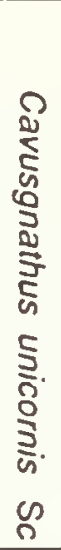 & 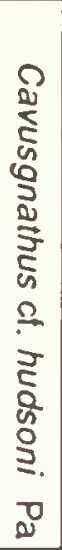 & 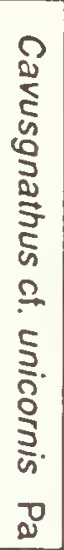 & 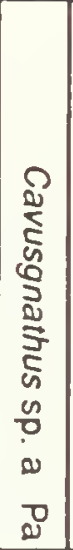 & 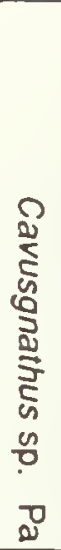 & 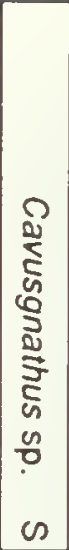 & 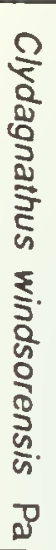 & 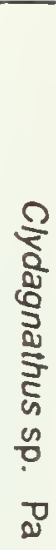 \\
\hline Lower Border & Cambeck & - & 13 & 108707 & 1.29 & 1490 & - & - & $\overline{-}$ & - & - & - & - & - & - & - & - & - & - & - & - & - & - & - & - \\
\hline Lower Border & Cambeck & Syringothyris Ls. & 13 & 108705 & 1.36 & 1427 & - & (1) & 1 & 4 & $2(2)$ & (1) & (1) & (12) & - & 5 & 1 & (1) & - & - & - & - & - & - & 一 \\
\hline Lower Border & Cambeck & - & 13 & 108704 & 122 & 1489 & - & - & - & 1 & - & - & 1 & (1) & - & - & - & - & - & - & - & - & (3) & - & - \\
\hline Lower Border & Cambeck & Whitrigg Serpula & 13 & 108702 & 140 & 1488 & - & - & - & - & - & - & - & - & - & - & - & - & - & - & - & - & - & - & (1) \\
\hline Lower Border & Cambeck & - & 13 & 108701 & 1.37 & 1487 & - & - & 1 & - & 4 & - & 2 & - & 1 & (3) & - & - & - & - & $2(1)$ & (4) & - & 5 & (1) \\
\hline Lower Border & Cambeck & - & 13 & 88776 & 1.30 & 1486 & - & - & - & 6 & - & - & 3 & $1(7)$ & (2) & 5 & 1 & - & - & - & - & - & (5) & - & - \\
\hline Lower Border & Cambeck & U Antiquatonia & 13 & 88773 & 133 & 1485 & - & - & - & - & - & 一 & - & (1) & (2) & - & - & - & - & - & - & - & - & - & 一 \\
\hline Lower Bopder & Cambeck & L Antiquatonia & 12 & LAG & 134 & 1522 & - & - & - & - & - & - & - & - & - & - & - & - & - & - & - & - & - & - & - \\
\hline Lower Border & Cambeck & L Antıquatonia & 12 & LA5 & 1.39 & 1521 & (1) & - & (1) & 1 & - & - & - & (2) & - & - & - & - & - & 1 & - & - & $(6)$ & - & - \\
\hline Lower Border & Cambeck & L Antiquatonia & 12 & LAI & 070 & 1383 & - & - & - & - & - & - & - & (1) & - & - & - & - & - & - & - & - & - & - & - \\
\hline Lower Border & MAVCAM & - & 12 & 88747 & 1.25 & 1480 & - & - & 1 & - & - & - & - & - & - & 2 & - & - & - & - & - & (1) & (8) & - & - \\
\hline Lower Border & Maın Algal & Main Algal 13 & 12 & 88744 & 1.17 & 1479 & - & - & - & - & - & - & - & - & - & - & - & - & - & - & - & - & - & - & - \\
\hline Lower Border & Main Algal & Main Algal 12 & 12 & 88743 & 1.23 & 1478 & - & - & - & - & - & - & - & - & - & - & - & - & - & - & - & - & - & - & - \\
\hline Lower Border & Main Algal & Main Algal 11 & 12 & 88740 & 1.44 & 1477 & - & - & - & - & - & - & - & - & - & - & - & - & - & - & - & - & - & - & - \\
\hline Lower Border & Main Algal & Main Algal 10 & 12 & 88735 & 1.40 & 1476 & - & - & - & - & - & 1 & 1 & - & - & $2(1)$ & (1) & - & - & - & - & - & (7) & - & - \\
\hline Lower Border & Main Algal & Main Algal 9 & 12 & 88732 & 1.36 & 1475 & - & - & - & - & 1 & - & - & (1) & 1 & 1 & - & - & - & - & - & (1) & - & - & - \\
\hline Lower Border & Main Algal & Main Algal 8 & 12 & 88729 & 144 & 1474 & - & - & - & - & - & - & - & 1 & (2) & 1 & - & - & - & - & - & - & $(8)$ & - & - \\
\hline Lower Border & Maın Algal & Burky Clough Ls. & 12 & 88727 & 1.34 & 473 & - & - & - & - & - & - & - & - & - & - & - & - & - & - & - & - & (5) & - & - \\
\hline Lower Border & Main Algal & Birky Clough Ls. & 12 & 88726 & 136 & 1472 & 2 & - & 1 & - & - & 1 & - & - & - & - & - & - & - & - & - & - & - & - & - \\
\hline Lower Border & Main Algal & Briky Clough Ls. & 12 & 88725 & 1.28 & 1471 & - & - & - & - & - & - & - & - & - & - & - & - & - & - & - & - & - & - & - \\
\hline Lower Border & Main Algal & Birky Clough Ls. & 12 & 88724 & 1.35 & 1470 & - & - & - & - & - & - & - & - & - & - & - & - & - & - & - & - & (5) & - & - \\
\hline Lower Border & Main Algal & Birky Clough LS & 12 & 88723 & 1.35 & 1469 & - & - & - & - & - & - & - & - & - & - & - & - & - & - & - & - & - & - & - \\
\hline Lower Border & Main Algal & eugh Ls. & 12 & 88722 & 1.22 & 1468 & - & - & - & - & - & - & - & - & - & - & - & - & - & - & - & - & - & - & - \\
\hline Lower Border & Main Algal & Birky Clough Ls. & 12 & 88721 & 1.36 & 1467 & - & - & - & - & - & - & - & - & - & - & - & - & - & - & - & - & - & - & - \\
\hline Lower Border & Main Algal & Main Algal 4 & 12 & 88720 & 137 & 1466 & - & - & - & - & - & - & - & - & - & - & - & - & - & - & - & - & - & - & - \\
\hline Lower Border & Main Algal & Main Algal 2 & 12 & 88718 & 1.43 & 1465 & - & - & - & - & - & - & - & - & - & - & - & - & - & - & - & - & - & - & - \\
\hline Lower Border & Main Algal & Main Algal 1 & 12 & 88717 & 134 & 1464 & - & - & - & - & 1 & 2 & 3 & - & - & - & (1) & - & - & - & - & (4) & (5) & - & - \\
\hline Lower Border & Main Algal & Main Algal 1 & 12 & 88715 & 136 & 1463 & - & - & - & - & - & - & - & - & - & - & - & - & - & - & - & - & - & - & - \\
\hline Lower Border & Bewcasile & nction Ls. & 1 & 88713 & 1.28 & 1462 & - & - & - & - & - & - & - & - & - & - & - & - & - & - & - & - & - & - & - \\
\hline Lower Border & Bewcasile & Junction Ls. & 10 & 88704 & 1.33 & 1406 & - & - & - & - & - & - & - & - & - & - & - & - & - & - & - & - & - & - & - \\
\hline Lower Border & Bewcasile & Peol LS. & 1 & 88702 & 130 & 1405 & - & - & - & - & - & - & - & - & - & - & - & - & - & - & - & 1 & - & - & - \\
\hline Lower Border & Bewcastle & Stack Cleugh Oolite & 10 & 88701 & 1.33 & 1404 (UF) & - & - & - & - & - & - & - & - & - & - & - & - & - & - & - & - & - & - & - \\
\hline Lower Border & Bewcasile & Rigghead Ls. & 10 & 1988610 & 1.29 & 1251 & - & - & (1) & - & - & - & - & - & - & - & - & - & - & - & - & - & - & - & - \\
\hline Lower Border & Bewcasile & - & 10 & 68 & 131 & 250 & - & - & - & - & - & - & - & - & - & - & - & - & - & - & - & - & - & - & - \\
\hline Lower Border & reasile & - & 1 & 188865 & 1.36 & 381 & - & - & - & - & - & - & - & - & - & - & - & - & - & - & - & - & - & - & - \\
\hline Lower Border & Bewcastle & ugh Ls. & 10 & 168863 & 132 & 1249 & - & - & - & - & - & - & - & - & - & - & - & - & - & - & - & - & - & - & - \\
\hline Lower Border & Bewcastle & Ashy Cleugh Ls. & 10 & 168861 & 1.30 & 1380 & - & - & - & - & - & - & - & - & - & - & - & - & - & - & - & - & - & - & - \\
\hline Lower Border & Bewcastle & - & 10 & 78866 & 1.17 & 1379 & - & - & - & - & - & - & - & - & - & - & - & - & - & - & - & - & - & - & - \\
\hline Lower Border & Bewcastle & - & 10 & 78864 & 1.06 & 1248 & - & - & - & - & - & - & - & - & - & - & - & - & - & - & - & - & - & - & - \\
\hline Lower Border & Bewcasile & - & 1. & & 1.31 & 342 & - & - & - & - & - & - & - & - & - & - & - & - & - & - & - & - & - & - & - \\
\hline Lower Border & rcasile & se Ls. & 1 & 62 & 143 & 1247 & - & - & - & - & - & - & - & - & - & - & - & - & - & - & - & - & - & - & - \\
\hline Lower Border & wcastle & Now House Ls & 10 & 58861 & 125 & 1378 & - & - & - & - & - & - & - & - & - & - & - & - & - & - & - & - & - & - & - \\
\hline Lower Border & Bewcasile & - & 10 & 117861 & 1.09 & 1377 & - & - & - & - & - & - & - & - & - & - & - & - & - & - & - & - & - & - & - \\
\hline Lower Border & Bewcasile & - & 10 & 87865 & 132 & 1376 & - & - & - & - & - & - & - & - & - & - & - & - & - & - & - & - & - & - & - \\
\hline Lower Border & Bewcastle & - & 10 & 87862 & 1.28 & 1375 & - & - & - & - & - & - & - & 一 & - & - & - & - & - & - & - & - & - & - & - \\
\hline Lower Border & Bewcasile & U Holmhead & 1 & 278626 & 1.32 & 1246 & - & - & - & - & - & - & - & - & - & - & - & - & - & - & - & - & - & - & - \\
\hline Lower Border & wcasile & - & 1 & 278622 & 1.11 & 1373 (UF) & - & - & - & - & - & - & - & - & - & - & - & - & - & - & - & - & - & - & - \\
\hline Lower Border & Bewcasile & L Holmhead & 10 & 278619 & 124 & 1372 & - & - & - & - & - & - & - & - & - & - & - & - & 1 & - & - & (1) & (4) & - & - \\
\hline Lower Border & Bewcastle & L Holmhead & 10 & $"$ & 123 & 1459 & - & - & - & - & - & - & - & - & - & - & - & - & - & - & - & - & - & - & - \\
\hline Lower Border & Bewcastle & Kitty Bock Ls & 10 & 278614 & 128 & 1245 & - & - & - & - & - & - & - & - & - & - & - & - & - & - & - & - & - & - & - \\
\hline Lower Border & Bewcastle & - & 10 & 3068610 & 0.91 & 1371 & - & - & - & - & - & - & - & - & - & - & - & - & - & - & - & - & - & - & - \\
\hline Lower Border & Bewcastle & - & 1 & 306868 & 1.10 & 1370 & - & - & - & - & - & - & - & - & - & - & - & - & - & - & - & - & - & - & - \\
\hline Lower Border & Bewcasile & - & 10 & 256866 & 123 & 1369 & - & - & - & - & - & - & - & - & - & - & - & - & - & - & - & - & - & - & - \\
\hline Lower Border & Bewcastle & - & 10 & 256862 & 119 & 1368 & - & - & - & - & - & - & - & - & - & - & - & - & - & - & - & - & - & - & - \\
\hline
\end{tabular}

APPENDIX IIc. Conodont elements recovered from the Bewcastle, Main Algal, and Cambeck formations, localities 10, 12, and 13. UF residue not completely picked; $\not$ cavusgnathid; $\nmid$ Hindeodus fragments?; r rare. 


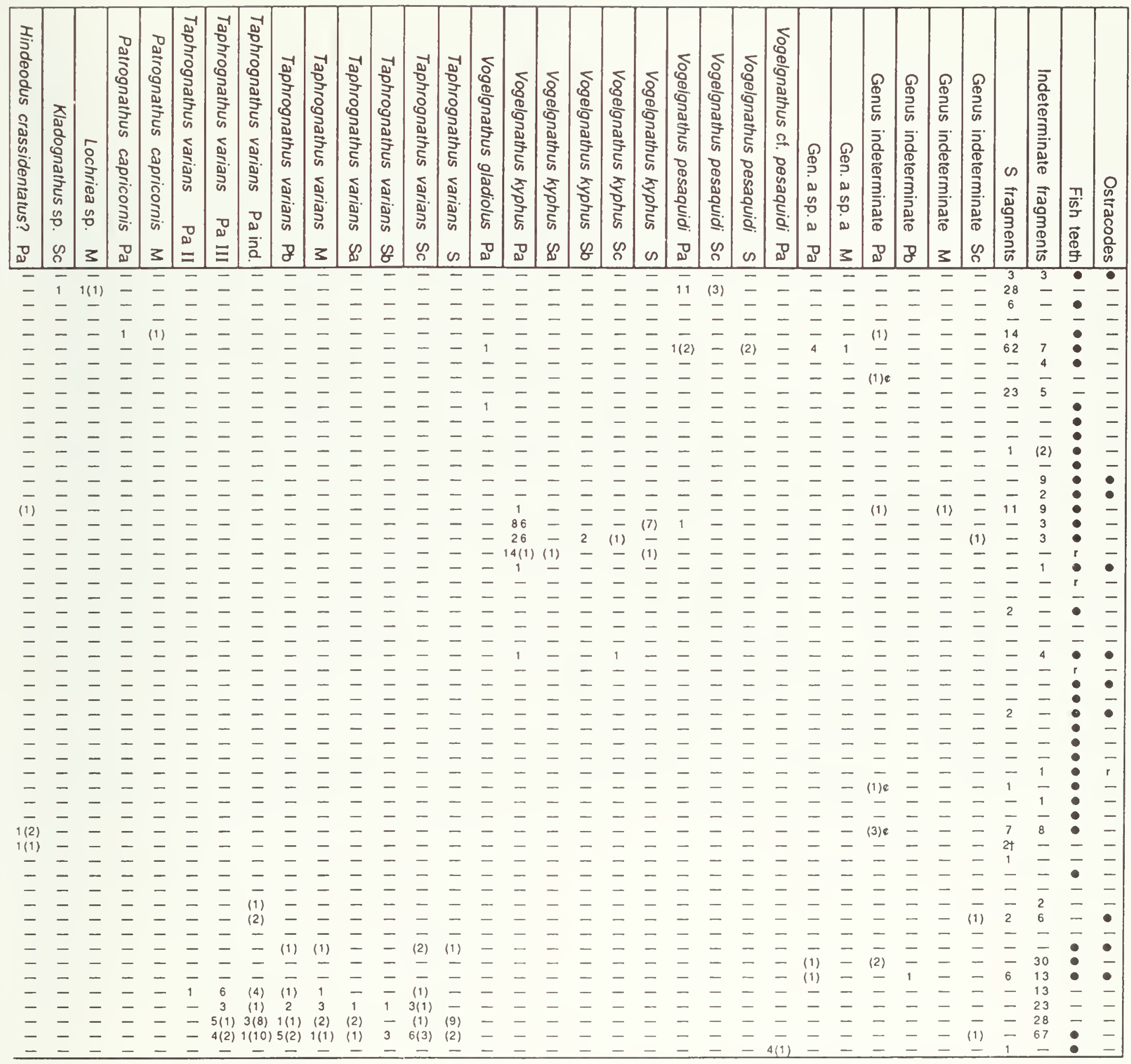




\begin{tabular}{|c|c|c|c|c|c|c|c|c|c|c|c|c|c|c|c|c|c|c|c|}
\hline $\begin{array}{l}\stackrel{\rho}{3} \\
\text { 등 }\end{array}$ & 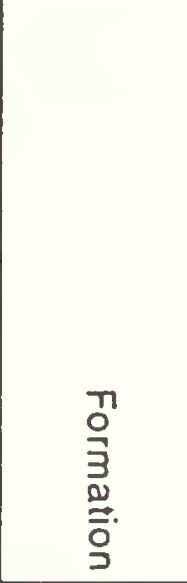 & $\begin{array}{l}5 \\
\frac{1}{3} \\
9 \\
0 \\
0\end{array}$ & $\begin{array}{l}5 \\
0 \\
0 \\
\equiv \\
\equiv\end{array}$ & 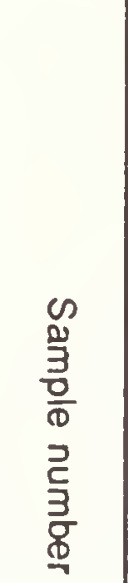 & 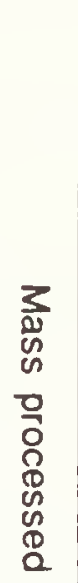 & 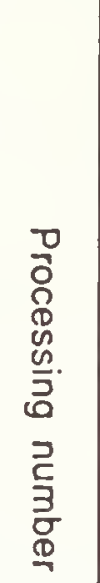 & 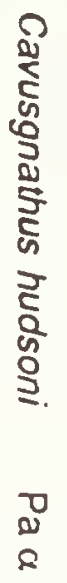 & 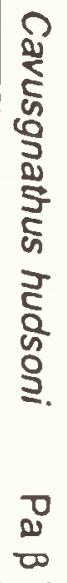 & 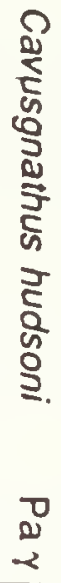 & 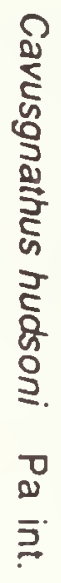 & 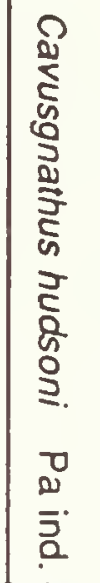 & 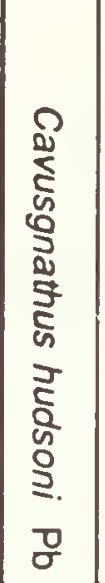 & 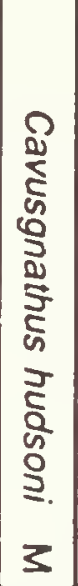 & 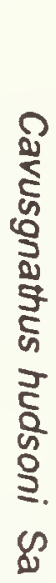 & 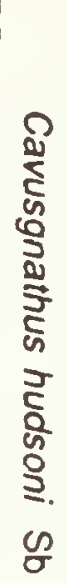 & 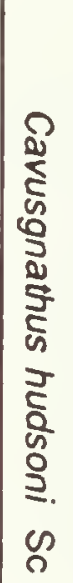 & 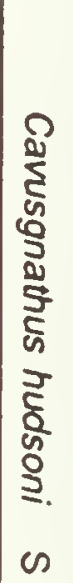 & 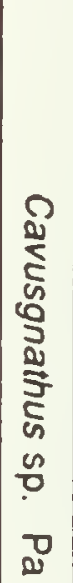 & 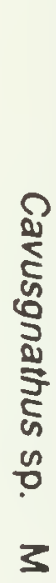 \\
\hline Lower Border & Liddel & - & 20 & 108792 & 1.44 & 1450 & - & 20 & 3 & 33 & $11(25)$ & 5 & $3(1)$ & (1) & - & - & - & - & - \\
\hline Middle Border & - & Harden & 17 & 108766 & 1.31 & 1430 & - & - & - & - & - & - & - & - & - & - & - & - & - \\
\hline Lower Border & Liddel & - & 17 & 108764 & 1.23 & 1515 & 1 & 13 & 4 & 5 & $4(16)$ & 一 & 2 & - & - & 1 & (1) & (5) & (1) \\
\hline Lower Border & Liddel & - & 17 & 108763 & 1.30 & 1514 & - & - & - & - & - & - & - & - & - & - & - & - & - \\
\hline Lower Border & Liddel & - & 17 & 108760 & 1.40 & 1512 & 1 & 2 & - & - & 一 & - & - & - & - & - & - & (5) & - \\
\hline Lower Border & Liddel & - & 17 & 108758 & 1.40 & 1511 & 5 & 16 & 4 & 16 & 8 & 10 & 2 & 3 & - & - & (7) & $1(3)$ & - \\
\hline Lower Border & Liddel & - & 17 & 108756 & 1.43 & 1509 & - & - & - & - & - & - & - & - & - & - & - & - & 一 \\
\hline Lower Border & Liddel & - & 17 & 108754 & 1.42 & 1508 & 1 & - & - & 2 & (3) & (1) & 3 & - & - & - & (7) & $(2)$ & 一 \\
\hline Lower Border & Liddel & - & 17 & 108752 & 1.49 & 1507 & - & - & - & - & - & - & - & - & - & - & - & - & - \\
\hline Lower Border & Liddel & - & 17 & 108751 & 1.43 & $1506^{\wedge}$ & 25 & 11 & - & 49 & $5(18)$ & $24(14)$ & 6 & 3 & 2 & $2(1)$ & $(10)$ & - & - \\
\hline Lower Border & Liddel & - & 17 & 108747 & 1.34 & 1505 & - & - & - & - & - & - & - & - & - & - & - & - & - \\
\hline Middle Border & - & Harden & 19 & 108745 & 1.20 & 1429 & - & - & - & - & - & - & - & - & - & - & - & - & - \\
\hline Lower Border & U Black Burn & - & 19 & 108742 & 0.86 & 1504 & - & - & - & - & 一 & - & - & - & - & - & - & - & 一 \\
\hline Lower Border & U Black Burn & - & 19 & 108739 & 0.93 & 1503 & - & - & - & - & - & - & - & - & - & - & - & - & - \\
\hline Lower Border & L Black Burn & - & 19 & 108737 & 0.96 & 1502 & - & - & - & - & - & - & - & - & - & - & - & - & - \\
\hline Lower Border & L Black Burn & - & 19 & 108735 & 1.09 & 1501 & - & - & - & - & - & - & - & - & - & - & - & - & - \\
\hline Lower Border & Arnton Foll & - & 21 & 108734 & $\begin{array}{ll}102 \\
1\end{array}$ & 1428 & - & - & - & - & - & - & - & - & - & - & - & - & - \\
\hline
\end{tabular}

APPENDIX IId. Conodont elements recovered from the Liddel, Black Burn, and Arnton Fell formations and the Harden Member, localities 17, 19-21. † juvenile; $₫$ cavusgnathid; * includes 2 juveniles; ‘ 18 anterior platform and blade fragments included in $C$. hudsoni $\mathrm{Pa}$ elements. 


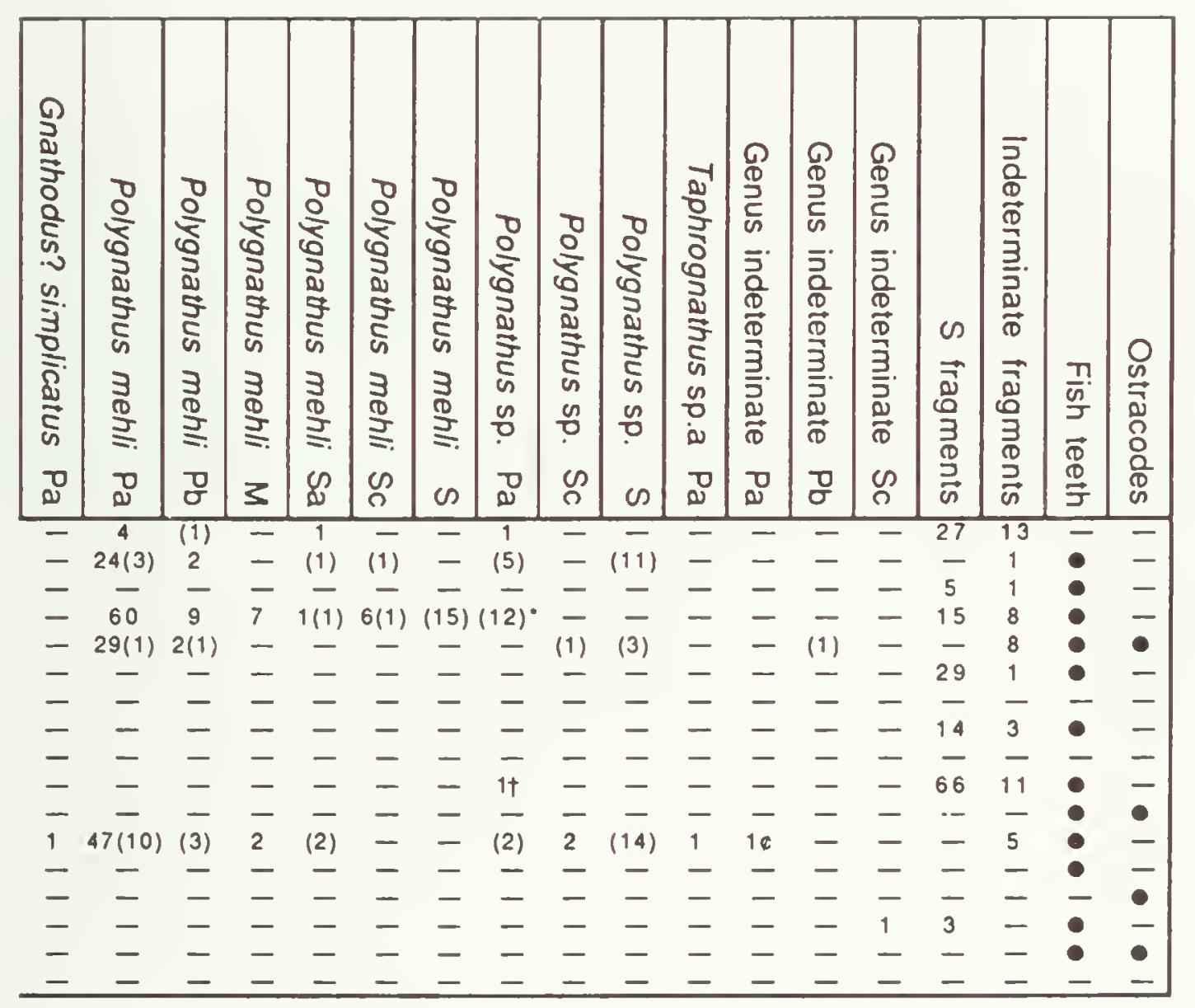




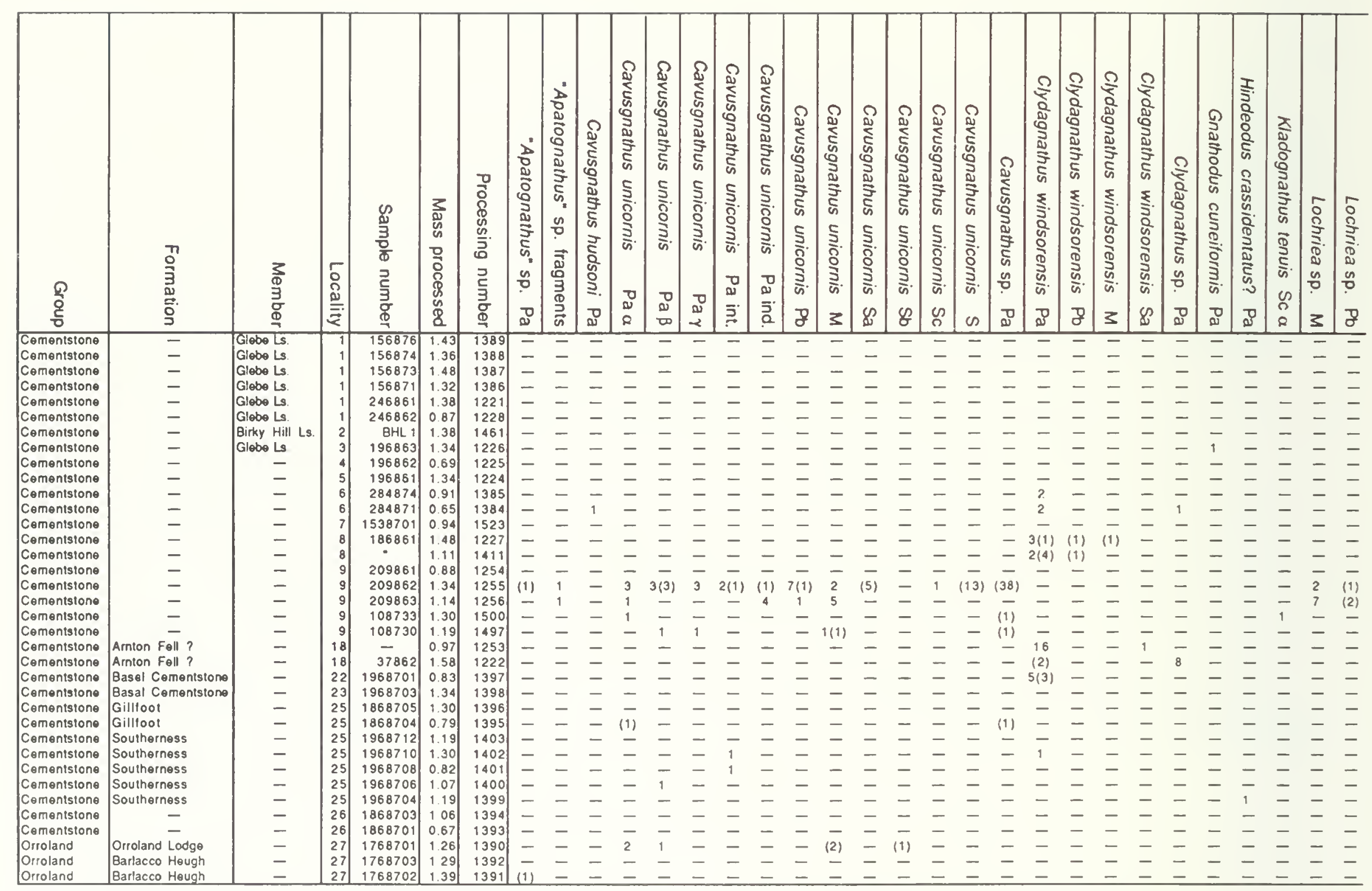

APPENDIX IIe. Conodont elements recovered from the Cementstone and Orroland groups, localities 1-9, 18, 22, 23, 25-27. 


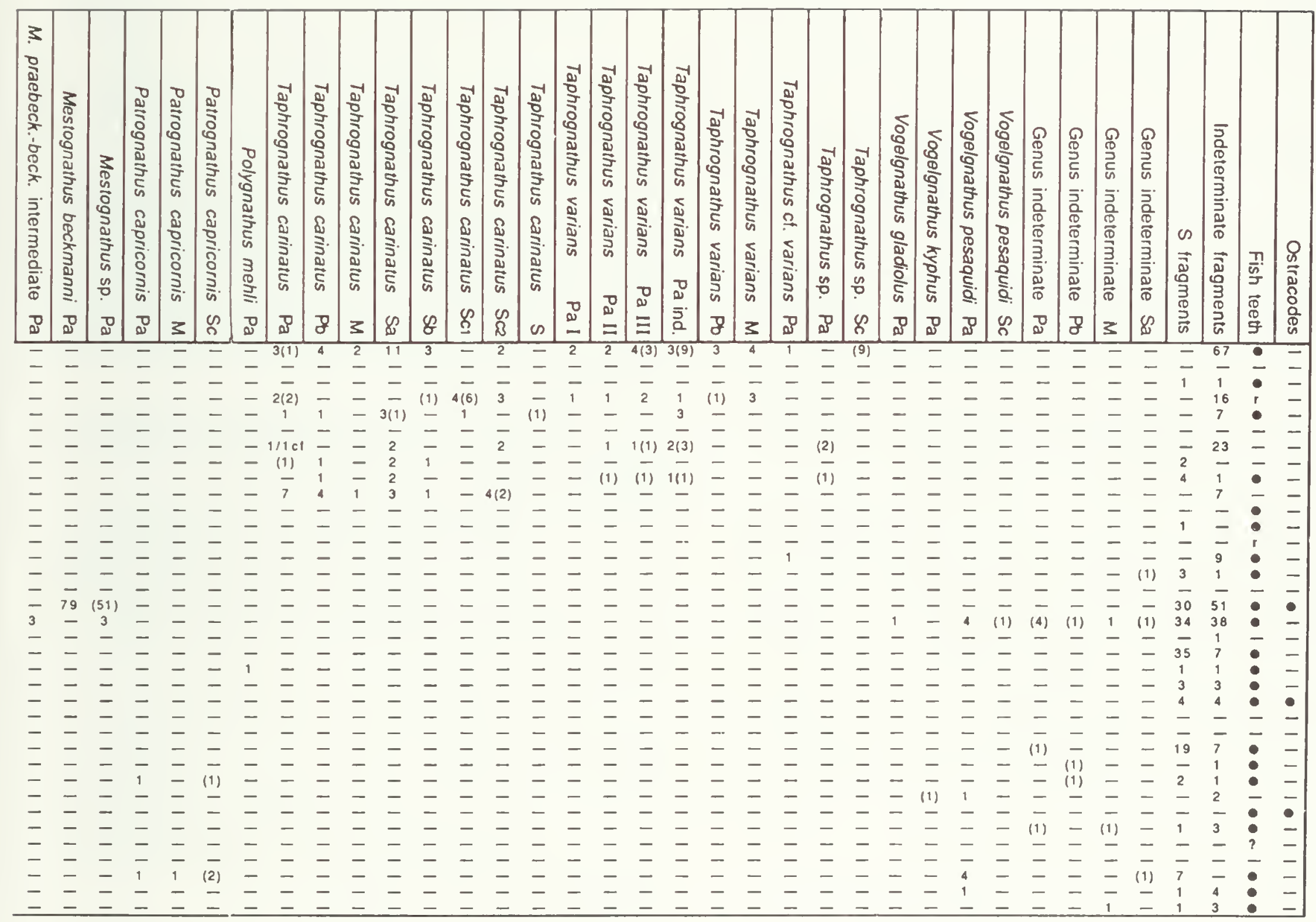




\section{Literature Cited}

ALBERCH, P., S. J. GOULD, G. F. OSTER, and D. S. WAKE

1979 Size and shape in ontogeny and phylogeny. Paleobiology 5:296-317.

ALDRIDGE, R. J.

1987 Conodont palaeobiology: a historical review. In Aldridge, R. J., ed., Palaeobiology of conodonts. Chichester, Ellis Horwood, pp. 11-34.

ALDRIDGE, R. J., D. E. G. BRIGGS, E. N. K. CLARKSON, and M. P. SMTTH

1986 The affinities of conodonts-new evidence from the Carboniferous of Edinburgh, Scotland. Lethaia 19:279-291.

ALDRIDGE, R. J., M. P. SMITH, R. D. NORBY, and D. E. G. BRIGGS 1987 The architecture and function of Carboniferous polygnathacean conodont apparatuses. In Aldridge, R. J., ed., Palaeobiology of conodonts. Chichester, Ellis Horwood, pp. 63-76.

ARMSTRONG, H. A. and M. A. PURNELL

1987 Dinantian conodont biostratigraphy of the Northumberland trough. Journal of Micropalaeontology 6:97-112.

AUSTIN, R. L 1973

1974

Phylogeny and homeomorphy of conodonts in the Lower Carboniferous. Gcological Society of America, Special Paper 141:105-116.

The biostratigraphic distribution of conodonts in Great Britain and the Republic of Ireland. International Symposium on Belgian Micropaleontological Limits, Namur, Publication 3:1-17.

AUSTIN, R. L., ed.

1987 Conodonts: investigative techniques and applications. Chichester, Ellis Horwood. 422 pp.

AUSTIN, R. L. and R. J. ALDRIDGE

1973 Conodonts from horizons with Goniatiles crenistria Phillips in North Wales and the Isle of Man. Geological Magazine 110:37-42.

AUSTIN, R. L. and R. B. DAVIES

1984 Problems of recognition and implications of Dinantian conodont biofacies in the Britis Isles. Geological Society of America, Special Paper 196:195-228.

AUSTIN, R. L. and P. J. HIL.L

1973 A Lower Avonian (K zone) conodont fauna from near Tintern, Monmouthshire, Wales. Geologica et Palaeontologica 7:123-134.

AUSTIN, R. L. and S. HUSRI

1974 Dinantian conodont faunas of County Clare, County Limerick and County Leitrim, an appendix. International Symposium on Belgian Micropaleontological Limits, Namur, Publication 3:18-69.
AUSTIN, R. L. and M. MITCHELL

1975 Middle Dinantian platform conodonts from County Fermanagh and County Tyrone, Northern Ireland. Geological Survey of Great Britain, Bulletin 55:43-54.

AUSTIN, R. L. and F. H. T. RHODES

1969 A conodont assemblage from the Carboniferous of the Avon Gorge, Bristol. Palaeontology 12:400-405.

BASSLER, R. S. 1925

Classification and stratigraphic use of conodonts. Geological Society of America, Bulletin 36:218-220. [Abstract]

BATESON, W. 1886

The ancestry of the Chordata. Quarterly Joumal of Microscopical Sciences 26:535-571.

BELKA, Z.

1985 Lower Carboniferous conodont biostratigraphy in the northeastern part of the Moravia-Silesia Basin. Acta Geologica Polonica 35:33-60.

BELT, E. S., E. C. FRESHNEY, and W. S. READ

1967 Sedimentology of Carboniferous cementstone facies, British Isles and eastern Canada. Journal of Geology 75:711-721.

BENGTSON, P.

1988 Open nomenclature. Palaeontology 31:223227.

BISCHOFF, G.

1957 Die Conodonten-Stratigraphie des rhenoherzynischen Unterkarbons mit Berücksichtigung der Wocklumeria-Stufe und der Devon/ Karbon-Grenze. Hessisches Landesamt für Bodenforschung, Abhandlungen 19:1-64.

BLACKWELDER, R. E.

1967 Taxonomy: a text and reference book. New York, John Wiley and Sons. 698 pp.

BOTT, M. H. P. 1987

Subsidence mechanisms of Carboniferous basins in northern England. In Miller, J., A. E. Adams, and V. P. Wright, eds., European Dinantian environments. Chichester, John Wiley and Sons, pp. 21-32.

BRANSON, E. B. 1938

Stratigraphy and paleontology of the Lower Mississippian of Missouri, Pt. 1. University of Missouri Studies 13:1-208. 
BRANSON, E. B. and M. G. MEHL

1934a Conodonts from the Grassy Creek Shale of Missouri. University of Missouri Studies 8:171-259.

1934b Conodonts from the Bushberg Sandstone and equivalent formations of Missouri. University of Missouri Studies 8:265-299.

1941a Caney conodonts of Upper Mississippian age. Denison University Bulletin, Journal of the Scientific Laboratories 35:167-178.

1941b Conodonts from the Keokuk Formation. Denison University Bulletin, Joumal of the Scienlific Laboratories 35:179-188.

1941c New and litule known Carboniferous conodont genera. Journal of Palcontology 15:97-106.

BRIGGS, D. E. G., E. N. K. CLARKSON, and R. J. ALDRIDGE

1983 The conodont animal. Lethaia 16:1-14.

BROWER, J. C. and W. A. BURROUGHS

1982 A simple method for quantitative biostratigraphy. In Cubith, J. M. and R. A. Reyment, eds., Quantitative stratigraphic correiation. New York, John Wiley and Sons, pp. 61-83.

BROWER, J. C. and K. M. KILE

1988 Seriation of an original data matrix as applied to paleoecology. Lethaia 21:79-93.

BURMEISTER, C. H. C.

1847 Handbuch der Entomologie. Vol. 5. Berlin, Enslin. 584 pp.

CATER, J. M. L., D. E. G. BRIGGS, and E. N. K. CLARKSON

1989 Shrimp-bearing sedimentary sequences in the Lower Carboniferous (Dinantian) Cementstone and Oil Shale Groups of northem Britain. Transactions of the Royal Society of Edinburgh (Earth Sciences) 80:5-15.

CHAUFF, K. M.

1981 Multielement conodont species from the Osagean (Lower Carboniferous) in Midcontinent North America and Texas. Palaeontographica (Abt. A) 175:140-169.

CISNE, J. L. and B. D. RABE

1978 Coenocorrelation: gradient analysis of fossil communities and its applications in stratigraphy. Lethaia 11:341-364.

CLARK, D. L. 1972

Early Permian crisis and its bearing on PermoTriassic conodont taxonomy. Geologica et Palaeontologica, SB 1:147-158.

CLARKE, W. J. 1960 Scottish Carboniferous conodonts. Geological CONWAY MORRIS, S. Society of Edinburgh, Transactions 18:1-31.

1990

Typhloesus wellsi (Melton and Scoth, 1973), a bizarre metazoan from the Carboniferous of Montana, U.S.A. Transactions of the Royal Society of London, Series B 327:545-624.
COOPER, C. L. 1939

1947 Upper Kinkaid (Mississippian) microfauna from Johnson County, Illinois. Journal of Paleontology 21:81-94.

CRAIG, G. Y. 1956

The Lower Carboniferous outlier of Kirkbean, Kirkcudbrightshire. Geological Society of Glasgow, Transactions 22:113-32.

DAVIES, R. B. 1980

DAY, J. B. W. 1970

DEAN, M. T. 1987

DEEGAN, C. E. 1973

DRUCE, E. C.

1969 Devonian and Carboniferous conodonts from the Bonaparte Gulf Basin, northern Australia and their use in international correlation. Australian Burcau of Mineral Resources, Geology and Geophysics, Bulletin 98:1-242.

1970 Lower Carboniferous conodonts from the northem Yarrol basin, Queensland, Australia. Australian Bureau of Mineral Resources, Geology and Geophysics, Bulletin 108:91-114.

1973 Upper Paleozoic and Triassic conodont distribution and the recognition of biofacies. In Rhodes, F. H. T., ed., Conodont paleozoology. Geological Society of America, Special Paper 141:191-237.

DRUCE, E. C., F. H. T. RHODES, and R. L. AUSTIN

1972 Statistical analysis of British Carboniferous conodont faunas. Journal of the Geological Society, London 128:53-70.

DZIK, J.

1976 Remarks on the evolution of Ordovician conodonts. Acta Palaeontologica Polonica 21:395455. 
FIEBER, F. X.

1866 Neue Gattungen und Arten in Homopteren (Cicadina Bur.). Verhandlungen der Zoologisch-botanischen Gesellschaft in Wien 16:497516.

FOWLER, A. 1936

1966

FROST, D. V. 1969

GARWOOD, E. J.

1931 The Tuedian beds of northern Cumberland and Roxburghshire east of the Liddel Water. Quarterly Journal of the Geological Society of London 87:97-159.

GLOBENSKY, Y.

1967 Middle and Upper Mississippian conodonts from the Windsor Group of the Atlantic Provinces of Canada. Journal of Palcontology 41:432-448.

GOULD, S. J.

1977 Ontogeny and phylogeny. Cambridge, Harvard University Press. 501 pp.

GROESSENS, E.

1971 Les conodontes du Toumaisien Supérieur de la

Belgique; note préliminaire. Belgium, Service

Géologique, Professional Paper 41:1-29.

HARRIS, R. W. and R. V. HOLLINGSWORTH

1933 New Pennsylvanian conodonts from Oklahoma. American Journal of Science, 5th series, 25:193-204.

HASS, W. H.

1953 Conodonts from the Bamett formation of Texas. United States Geological Survey, Professional Paper 243:69-94.

1959 Conodonts from the Chappel limestone of Texas. United States Geological Survey, Professional Paper 294J:365-400.

HASZELDINE, R. S.

1984 Carboniferous North Atlantic palaeogeography: stratigraphic evidence for rifting, not megashear or subduction. Geological Magazine 121:443-463.

1988 Crustal lineaments in the British Isles: their relationship to Carboniferous basins. In Besley, B. and G. Kelling, eds., Sedimentation in a synorogenic basin complex; the Upper Carboniferous of NW Europe. Glasgow, Blackie, pp. 5368 .
HIGGINS, A. C.

1961 Some Namurian conodonts from North Staffordshire. Geological Magazine 98:210 224.

1971 Conodont biostratigraphy of the Late Devonian-early Carboniferous rocks of the south central Cantabrian Cordillera. Trabajos de Geologia 3:179-192.

1975 Conodont zonation of the Late Visean-early Westphalian strata of the south and central Pennines of northem England. Bulletin of the Geological Survey of Great Britain 53:1-90.

HIGGINS, A. C. and R. L. AUSTIN, eds.

1985 A stratigraphical index of conodonts. Chichester, Ellis Horwood. 263 pp.

HIGGINS, A. C. and W. J. VARKER

1982 Lower Carboniferous conodont faunas from Ravenstonedale, Cumbria. Palaeontology 25: 145-166.

HINDE, G. J.

1879 On conodonts from the Chazy and Cincinnati Group of the Cambro-Silurian, and from the Hamilton and Genesee-Shale divisions of the Devonian, in Canada and the United States. Quarterly Joumal of the Geological Society, London 35:351-369.

1900 Notes and descriptions of new species of Scotch Carboniferous conodonts. Transactions of the Natural History Society of Glasgow 5:338-346.

HOLLAND, G. H., M. G. AUDLEY-CHARLES, M. G. BASSETT, J. W. COWIE, D. CURRY, F. J. FITCH, J. M. HANCOCK, M. R. HOUSE, J. K. INGHAM, P. E. KENT, N. MORTON, W. H. C. RAMSBOTTOM, P. F. RAWSON, D. B. SMITH, C. J. STUBBLEFIELD, H. S. TORRENS, PEIGI WALLACE, and A. W. WOODLAND

1978 A guide to stratigraphical procedure. Geological Society of London, Special Report 10:1-18.

HOROWTTZ, A. S. and C. B. REXROAD

1982 An evaluation of statistical reconstructions of multielement conodont taxa from Middle Chesterian rocks (Carboniferous) in southern Indiana. Joumal of Paleontology 56:959-969.

HUDDLE, J. W. 1934

Conodonts from the New Albany shale of Indiana. Bulletins of American Paleontology 21(72):1-136.

JENKINS, T. B. H.

1974 Lower Carboniferous conodont biostratigraphy of New South Wales. Palaeontology 17:909924.

JEPPSSON, L and G. K. MERRILL

1982 How best to designate obsolete taxonomic names and concepts: examples among conodonts. Journal of Paleontology 56:1489-1493.

JOHNSON, G. A. L.

1981 Geographical evolution from Laurasia to Pangaea. Proceedings of the Yorkshire Geological Society $43: 221-252$. 
1984

Subsidence and sedimentation in the Northumberland trough. Proceedings of the Yorkshire Geological Society 45:71-83.

JOHNSTON, I. S. 1976

The conodont biostratigraphy of some Lower Carboniferous (Courceyan Stage) rocks of Central Ireland. Ph.D. Thesis, University of Dublin.

JOHNSTON, I. S. and A. C. HIGGINS

1981 Conodont faunas from the Lower Carboniferous rocks at Hook Head, County Wexford. Journal of Earth Science (Dublin) 4:83-96.

KIMBELL, G. S., R. A. CHADWICK, D. W. HOLLIDAY, and O. C. WERNGREN

1989 1966

1971 Patrognathus and Siphonodella (Conodonta)

Structure and evolution of the Northumberland trough from new seismic reflection data and its bearing on models of continental extension. Journal of the Geological Society, London 146:775-787.

Upper Devonian and Lower Mississippian conodont zones in Montana, Wyoming and South Dakota. University of Kansas Paleontological Contributions, Paper 3:1-43. from the Kinderhookian (Lower Mississippian) of westem Kansas and southwestem Nebraska. Kansas State Geological Survey, Bulletin 202(3):1-14.

KLAPPER, G. and G. M. PHILIP

1971 Devonian conodont apparatuses and their vicarious skeletal elements. Lethaia 4:429-452.

KOZUR, H. 1976

Paleoecology of Triassic conodonts and its bearing on multielement taxonomy. Geological Association of Canada, Special Paper 15:313324.

LANE, H. R.

1967 Uppermost Mississippian and Lower Pennsylvanian conodonts from the type Morrowan region, Arkansas. Journal of Paleontology 41:920-942.

1968 Symmetry in conodont element-pairs. Journal of Paleontology 42:1258-1263.

LANE, H. R., C. A. SANDBERG, and W. ZIEGLER

1980 Taxonomy and phylogeny of some Lower Carboniferous conodonts and preliminary standard post-Siphonodella zonation. Geologica et Palaeontologica 14:117-164.

LEEDER, M. R. 1971

Initiation of the Northumberland Basin. Geological Magazine 108:511-516.

1972 Upper Old Red Sandstone-Tournaisian sedimentology and the initiation and origin of the Northumberland Basin. Ph.D. Thesis, University of Reading. 1974a The origin of the Northumberland Basin. Scottish Journal of Geology 10:283-296.

1974b Lower Border Group (Tournaisian) fluviodeltaic sedimentation and palaeogeography of the Northumberland Basin. Proceedings of the Yorkshire Geological Society 40:129-180.

1975a Lower Border Group (Toumaisian) limestones from the Northumberland Basin. Scottish Journal of Geology 11:151-167.

1975b Lower Border Group (Tournaisian) stromatolites from the Northumberland Basin. Scottish Journal of Geology 11:207-226.

1988 Recent developments in Carboniferous geology: a critical review with implications for the British Isles and N.W. Europe. Proceedings of the Geologists' Association 99:73-100.

LEEDER, M. R. and A. McMAHON

1988Upper Carboniferous (Silesian) basin subsidence in northern Britain. In Besley, B. and G. Kelling, eds., Sedimentation in a synorogenic basin complex; the Upper Carboniferous of Northwest Europe. Glasgow, Blackie, pp. 43-52.

LIPNJAGOV, O. M.

1979 Conodonts of the Ct1A and Ct1B of the Donetz Basin. Geological Survey of Belgium, Professional Paper 5(116):41-49.

LUMSDEN, G. I., W. TULLOCH, M. F. HOWELLS, and A. DAVIES

1967 The geology of the neighbourhood of Langholm. Memoir of the Geological Survey of the United Kingdom. 255 pp.

MAPES, R. H. and C. B. REXROAD

1986 Conodonts from the Imo Formation (Upper Chesterian) north central Arkansas. Geologica et Palaeontologica 20:113-123.

MARCHANT, T. R.

1978 The stratigraphy and micropalaeontology of the Lower Carboniferous (Courceyan-Arundian) of the Dublin Basin, Ireland. Ph.D. Thesis, University of Dublin.

MATTHEWS, S. C.

1973 Notes on open nomenclature and on synonymy lists. Palacontology 16:713-719.

MATTHEWS, S. C. and D. NAYLOR

1973 Lower Carboniferous conodont faunas from south-west Ireland. Palaeontology 16:335-380.

MAYR, E.

1963 Animal species and evolution. Cambridge, Harvard University Press. $797 \mathrm{pp}$.

MEHL, M. G. and L. A. THOMAS

1947 Conodonts of the Fern Glen of Missouri. Denison University Bulletin, Journal of the Scientific Laboratories 47:3-19.

MEISCHNER, D.

1970 Conodonten-Chronologie des deutschen Karbons. 6th International Congress on Stratigraphy and Carboniferous Geology, Sheffield 1967. Compte Rendu 3:1169-1180. 
METCALFE, I.

1980 Conodont faunas and age of the Raygill Quarry limestones (Embsay Limestone), Lothersdale, Yorkshire. Proceedings of the Yorkshire Geological Society 43:169-178.

1981 Conodont zonation and correlation of the Dinantian and early Namurian strata of the Craven Lowlands of northern England. Institute of Geological Sciences, Great Britain, Report 80/ 10:1-70.

MILLER, S. A. 1889

North American geology and palacontology for the use of amateurs, students and scientists. Cincinnati, Western Methodist Book Concern. 718 pp.

MOORE, R. C. and P. C. SYLVESTER-BRADLEY

1957 Suggested new article: Proposed recognition of the concept of "parataxon" and the provisions of the rules for the nomenclature of units in this category. Bulletin of Zoological Nomenclature 15(A):5-13.

MÜLLER, K. J. and E. M. MÜLLER

1957 Early Upper Devonian (Independence) conodonts from Iowa, Part 1. Journal of Palcontology 31:1069-1108.

NICOLL, R. S.

1971 Stratigraphy and conodont paleontology of the Sanders Group (Mississippian) in Indiana and adjacent Kentucky. Ph.D. Thesis, University of Iowa.

1980 The multielement genus Apatognathus from the Late Devonian of the Canning Basin, Western Australia. Alcheringa 4:133-152.

1985 Multielement composition of the conodont species Polygnathus xylus xylus Stauffer, 1940 and Ozarkodina brevis (Bischoff and Ziegler, 1957) from the Upper Devonian of the Canning Basin, Western Australia. BMR Journal of Australian Geology and Geophysics 9:133-147.

1987 Form and function of the Pa element in the conodont animal. In Aldridge, R. J., ed., Palaeobiology of conodonts. Chichester, Ellis Horwood, pp. 77-90.

NICOLL, R. S. and C. B. REXROAD

1975 Stratigraphy and conodont paleontology of the Sanders Group (Mississippian) in Indiana and adjacent Kentucky. Indiana Geological Survey, Bulletin 51:1-36.

NICOLL, R. S. and E. C. DRUCE

1979 Conodonts from the Fairfield Group, Canning Basin, Western Australia. Australian Bureau of Mineral Resources, Geology and Geophysics, Bulletin 190:1-134.

NORBY, R. D.

1976 Conodont apparatuses from Chesterian (Mississippian) strata of Montana and Illinois. Ph.D. Thesis, University of Illinois at Urbana-Champaign.
NORBY, R. D. and C. B. REXROAD

1985 Vogelgnathus, a new Mississippian conodont genus. Indiana Geological Survey, Occasional Paper 50:1-14.

ORD, D. M., H. CLEMMEY, and M. R. LEEDER

1988 Interaction between faulting and sedimentation during Dinantian extension of the Solway basin, SW Scotland. Journal of the Geological Society, London 145:249-259.

PANDER, C. $\mathrm{H}$.

1856 Monographie der fossilen Fische des silurischen Systems der russischbaltischen Gouvernements. Akademie der Wissenschaften St Petersburg. $91 \mathrm{pp}$.

PIERCE, R. W. and R. L. LANGENHEIM, Jr.

1974 Platform conodonts of the Monte Cristo Group, Mississippian, Arrow Canyon Range, Clark County, Nevada. Journal of Paleontology 48:149-169.

PLINT, H. A. and P. H. von BITTER

1986 Windsor Group (Lower Carboniferous) conodont biostratigraphy and palaeoecology, Magdalen Islands, Quebec, Canada. Canadian Journal of Earth Sciences 23:439-453.

PURNELL, M. A.

1989 Dinantian shallow shelf conodonts of the Northumberland trough. Ph.D. Thesis, University of Newcastle Upon Tyne.

PURNELL, M. A. and P. H. von BITTER

1992 Vogelgnathus Norby and Rexroad (Conodonta): new species from the Lower Carboniferous of Atlantic Canada and Northern England. Joumal of Paleontology 66:311-332.

RABIEN, A.

1954 Zur Taxionomie und Chronologie der oberdevonischer Ostracoden. Hessisches Landesamt für Bodenforschung, Abhandlungen $9.268 \mathrm{pp}$.

RAUP, D. M. and S. M. STANLEY

1978 Principles of paleontology. San Francisco, Freeman. 481 pp.

REES, J.

1987 The Carboniferous geology of the Boyne valley area, Ireland. Ph.D. Thesis, University of Dublin.

REXROAD, C. B.

1957 Conodonts from the Chester Series in the type area of southwestern Illinois. Illinois State Geological Survey, Report of Investigations 199:1-43.

1958a Conodonts from the Glen Dean Formation (Chester) of the Illinois Basin. Illinois State Geological Survey, Report of Investigations 209:1-27. 
The conodont homcomorphs Taphrognathus and Streptognathodus. Journal of Palcontology 32:1158-1159.

1981 Conodonts from the Vienna Limestone Mcmber of the Branchville Formation (Chesterian) in southern Indiana. Indiana Geological Survey, Occasional Paper 34:1-16.

REXROAD, C. B. and C. COLLINSON

1961 Preliminary range chart of conodonts from the Chester Series (Mississippian) in the Illinois Basin. Illinois State Geological Survey, Circular 319:1-11.

1963 Conodonts from the St. Louis Formation (Valmeycran Series) of Illinois, Indiana and Missouri. Illinois State Geological Survey, Circular 355:1-28.

1965 Conodonts from the Keokuk, Warsaw, and Salem formations (Mississippian) of Illinois. lllinois State Geological Survey, Circular 388:1-26.

REXROAD, C. B. and W. M. FURNISH

1964 Conodonts from the Pella Formation (Mississippian), south-central lowa. Journal of Palcontology 38:667-676.

REXROAD, C. B. and A. S. HOROWITZ

1990 Conodont paleoecology and multielement associations of the Beaver Bend Limestone (Chesterian) in Indiana. In Ziegler, W., ed., Papers on conodonts and Ordovician to Triassic conodont stratigraphy. Courier Forschungsinstitut Senckenberg 118:439-537.

REXROAD, C. B. and R. S. NICOLL.

1965 Conodonts of the Menard Formation (Chester Series) of the Illinois Basin. Indiana Geological Survey, Bulletin 39:1-28.

REXROAD, C. B. and T. L. THOMPSON

1979 A spathognathodont lineage of Mississippian conodonts. Lethaia 12:235-243.

REXROAD, C. B. and W. J. VARKER

1992 The new Mississippian conodont genus Synclydognathus. Journal of Paleontology 66:165170.

REYNOLDS, M. J.

1970 A Lower Carboniferous conodont fauna from Flintshire, North Wales. Bulletin of the Geological Survey of Great Britain 32:1-19.

RHODES, F. H. T., R. L. AUSTIN, and E. C. DRUCE

1969 British Avonian (Carboniferous) conodont faunas, and their value in local and intercontinental correlation. Bulletin of the British Museum (Natural History), Geology Supplement 5:1313.

RICHTER, R.

1948 Einführung in die Zoologische Nomenclatur. Kramer, Frankfurt a. M. 252 pp.

ROBISON, R. A., ed.

1981 Treatise on invertebrate paleontology, part W, Miscellanea, supplement 2, Conodonta. Lawrence, Geological Society of America and University of Kansas. 202 pp.
ROBSON, D. A. 1956

A sedimentary study of the Fell Sandstones of the Coquet valley, Northumberland. Quarterly Joumal of the Geological Society, London 112:241-262.

ROUNDY, P. V. 1926

Part 2, The microfauna. In Roundy, P. V., G. H. Girty, and M. I. Goldman, Mississippian formations of San Saba County, Texas. United States Geological Survey, Professional Paper 146:523.

RUPPEL, S. C. 1979

RUPPEL, S. C. and T. M. LEMMER

Conodonts from the Lower Mississippian Fort Payne and Tuscumbia formations of northern Alabama. Journal of Paleontology 53:55-70.

1986 Mississippian conodonts from the southern Texas Panhandle. University of Texas Geological Circular 86-7:1-36.

SANDBERG, C. A. and W. ZIEGLER

1979 Taxonomy and biofacies of important conodonts of Late Devonian styriacus-Zone, United States and Germany. Geologica et Palaeontologica 13:173-212.

SCOTT, A. J. and C. COLLINSON

1961 Conodont faunas from the Louisiana and McCraney formations of Illinois, Iowa and Missouri. Missouri Geology Survey, Report of Investigations 27:110-141.

SCOTT, H. W.

1942 Conodont assemblages from the Heath Formation, Montana. Journal of Paleontology 16:293-300.

SMITH, M. P.

1990 The Conodonta-palacobiology and evolutionary history of a major Palaeozoic chordate group. Geological Magazine 127:365-369.

SPRINGER, D. A. and R. K. BAMBACH

1985 Gradient versus cluster analysis of fossil assemblages: a comparison from the Ordovician of southwestern Virginia. Lethaia 18:181198.

SWEET, W. C. 1970

Uppermost Permian and Lower Triassic conodonts of the Salt Range and Trans-Indus ranges, West Pakistan. In Kummel, B. and C. Teichert, eds., Stratigraphic boundary problems: Permian and Triassic of West Pakistan. University of Kansas Department of Geology Special Publication 4:207-275.

1981a Macromorphology of elements and apparatuses. In Robison, R. A., ed., Treatise on invertebrate paleontology, part W, Miscellanea, supplement 2, Conodonta. Lawrence, Geological Society of America and University of Kansas, pp. W5-W20.

1981b Glossary of morphological and structural terms for conodont elements and apparatuses. In 
Robison, R. A., ed., Treatise on invertebrate paleontology, part W, Miscellanea, supplement 2, Conodonta. Lawrence, Geological Society of America and University of Kansas, pp. W60 W67.

1988 The Conodonta: morphology, taxonomy, paleoecology, and evolutionary history of a longextinct animal phylum. Oxford Monographs on Geology and Geophysics No. 10. Oxford, Clarendon Press. 212 pp.

THOMPSON, T. L.

1967 Conodont zonation of Lower Osagean rocks (lower Mississippian) of southwestem Missouri. Missouri Geological Survey, Report of Investigations 39:1-88.

THOMPSON, T. L. and L. D. FELLOWS

1970 Stratigraphy and conodont biostratigraphy of Kinderhookian and Osagean (Lower Mississippian) rocks of southwestern Missouri and adjacent areas. Missouri Geological Survey, Report of Investigations 45:1-263.

THOMPSON, T. L. and E. D. GOEBEL

1969 Conodonts and stratigraphy of the Meramecian Stage (Upper Mississippian) in Kansas. Kansas State Geological Survey, Bulletin 192:1-56.

TUBBS, P. K.

1986 Opinion 1415, Polygnathus bilineatus Roundy, 1926 designated as type species of Gnathodus Pander, 1856 (Conodonta). Bulletin of Zoological Nomenclature 43:262-263.

VARKER, W. J.

1967 Conodonts of the genus Apatognathus Branson and Mehl from the Yoredale Series of the north of England. Palacontology 10:124-141.

VARKER, W. J. and R. L. AUSTIN

1974 The significance of Adetognathus unicornis (Rexroad and Burton) in the Mirk Fell Beds (E2a) of the north of England. Transactions of the Leeds Geological Association 8:399-408.

VARKER, W. J. and G. D. SEVASTOPULO

1985 The Carboniferous System: part 1-conodonts of the Dinantian Subsystem from Great Britain and Ireland. In Higgins, A. C. and R. L. Austin, eds., A stratigraphical index of conodonts. Chichester, Ellis Horwood, pp. 167-210.

von BITTER, P. H.

1976 Paleoecology and distribution of Windsor Group (Visean-?Early Namurian) conodonts, Port Hood Island, Nova Scotia, Canada. Geological Association of Canada, Special Paper $15: 225-241$. von BITTER, P. H. and R. L. AUSTIN

1984 The Dinantian Taphrognathus transatlanticus conodont range zone of Great Britain and Atlantic Canada. Palaeontology 27:95-111.

von BITTER, P. H. and H. A. PLINT

1987 Conodonts of the Windsor Group (Lower Carboniferous), Magdalen Islands, Quebec, Canada. Journal of Paleontology 61:346-362.

von BITTER, P. H. and H. A. PLINT-GEBERL

1982 Conodont biostratigraphy of the Codroy Group (Lower Carboniferous), southwestern Newfoundland, Canada. Canadian Journal of Earth Sciences 19:193-221.

von BITTER, P. H., C. A. SANDBERG, and M. J. ORCHARD

1986 Phylogeny, speciation, and palaeoecology of the Early Carboniferous (Mississippian) conodont genus Mestognathus. Royal Ontario Museum, Life Sciences Contributions 143:1115.

WAGNER, R. H., A. C. HIGGINS, and S. V. MEYEN

1979 The Carboniferous of the U.S.S.R. Leeds, Yorkshire Goological Society. 247 pp.

WELLES, S. P.

1947 Vertebrates from the upper Moenkopi formation of northem Arizona. University of California, Geological Science Bulletin 27(7):241294.

WESTOLL, T. S., D. A. ROBSON, and R. GREEN

1955 A guide to the geology of the district around Alnwick, Northumberland. Proceedings of the Yorkshire Geological Society 30:61-100.

YOUNGQUIST, W. L. and A. K. MILLER

1949 Conodonts from the late Mississippian Pella Beds of south-central Iowa. Journal of Paleontology 23:617-622.

ZIEGLER, W., ed.

1975 Catalogue of conodonts, volume II. Stuttgart, E. Schweizerbart'sche Verlagsbuchhandlung. 404 pp.

1977 Catalogue of conodonts, volume III. Stuttgart, E. Schweizerbart'sche Verlagsbuchhandlung. 574 pp.

1981 Catalogue of conodonts, volume IV. Stuttgart, E. Schweizerbart'sche Verlagsbuchhandlung. $445 \mathrm{pp}$. 
Plates 
Figs. 1a, b. Hindeodus crassidentatus (Branson and Mehl)?. Lateral and upper views of Pa elenient ROM 48777, sample $78864, x 100$.

Figs. 2-14. Cavusgnathus hudsoni (Metcalfe) x60.

$2 \mathrm{a}-\mathrm{c}$. Lateral, lower, and upper views of sinistral $\mathrm{Pa} \beta$ element ROM 48778, sample 108751.

3a, b. Lateral and upper views of immature sinistral $\mathrm{Pa} \alpha$ element ROM 48779, sample 108751.

4a, b. Lateral and upper views of immature sinistral $\mathrm{Pa}$ element ROM 48780, sample 108751.

$5 \mathrm{a}-\mathrm{c}$. Lateral, upper, and lower views of sinistral $\mathrm{Pa} \alpha / \beta$ element ROM 48781, sample 108751.
6. Upper view of aberrant dextral Pa element ROM 48782 , sample 108758 .

7a, b. Lateral and upper views of variant dextral $\mathrm{Pa} \beta / \gamma$ eiement ROM 48783, sample 108764.

8. Lateral view of dextral $\mathrm{Pa} \gamma$ element ROM 48784, sample 108764.

9. Lateral view of $\mathrm{Pb}$ element ROM 48786, sample 108751.

10. Lateral view of Sc element ROM 48785, sample 88754.

11. Posterior view of Sa element ROM 48787, sample 108751.

12. Lateral view of Sc element ROM 48788, sample 108751.

13. Lateral view of Sb element ROM 48789, sample 108751.

14. Lateral view of M element ROM 48790, sample 108754. 

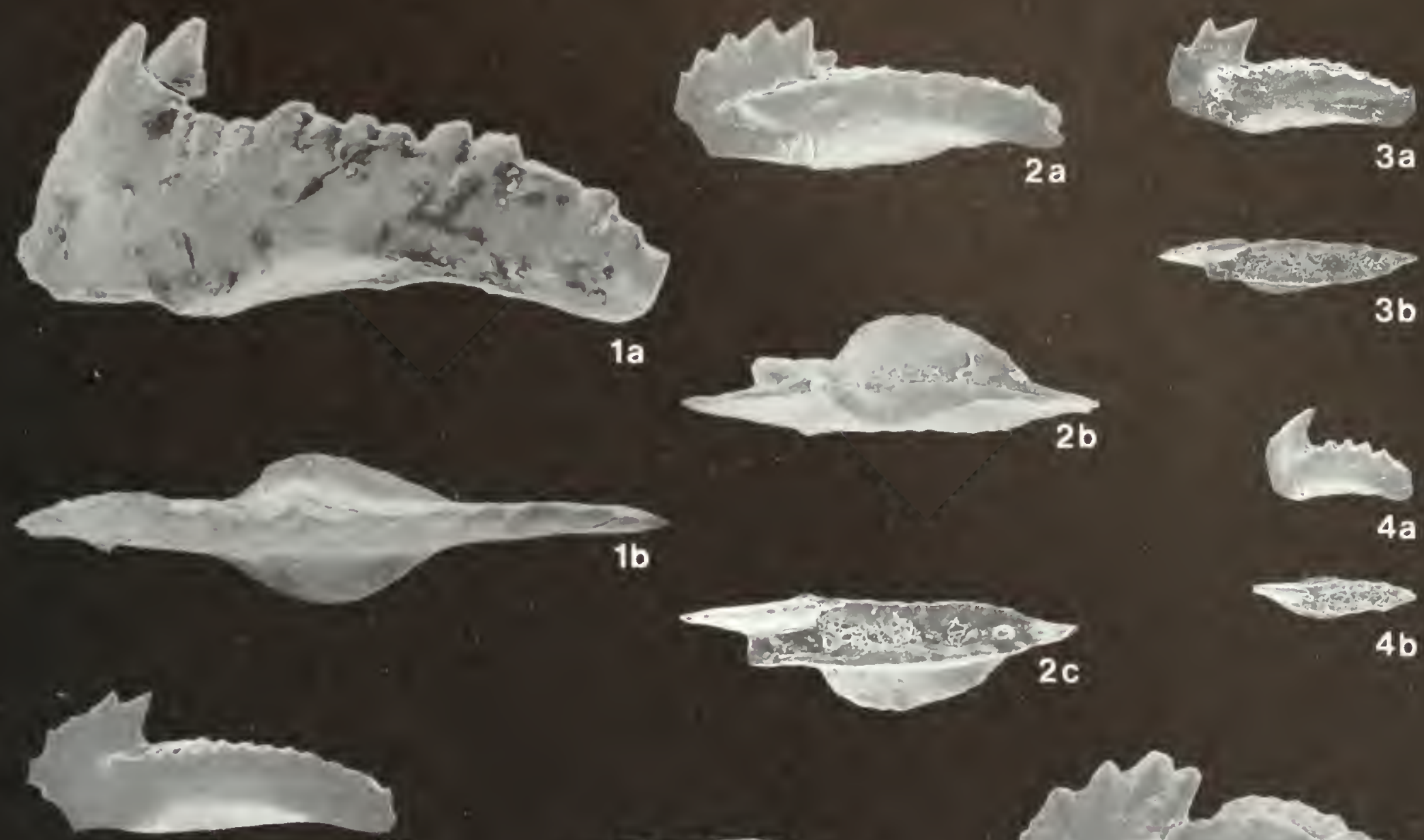

$5 a$
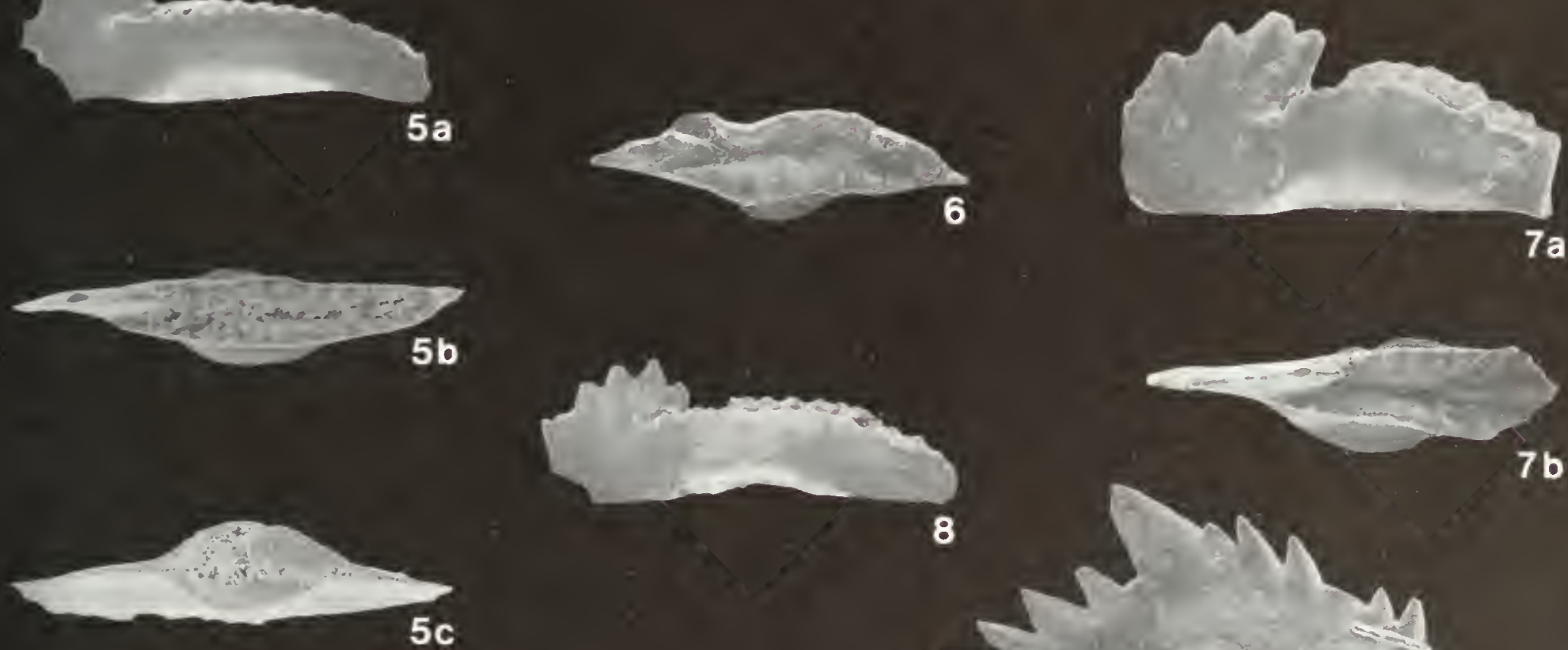

$5 c$
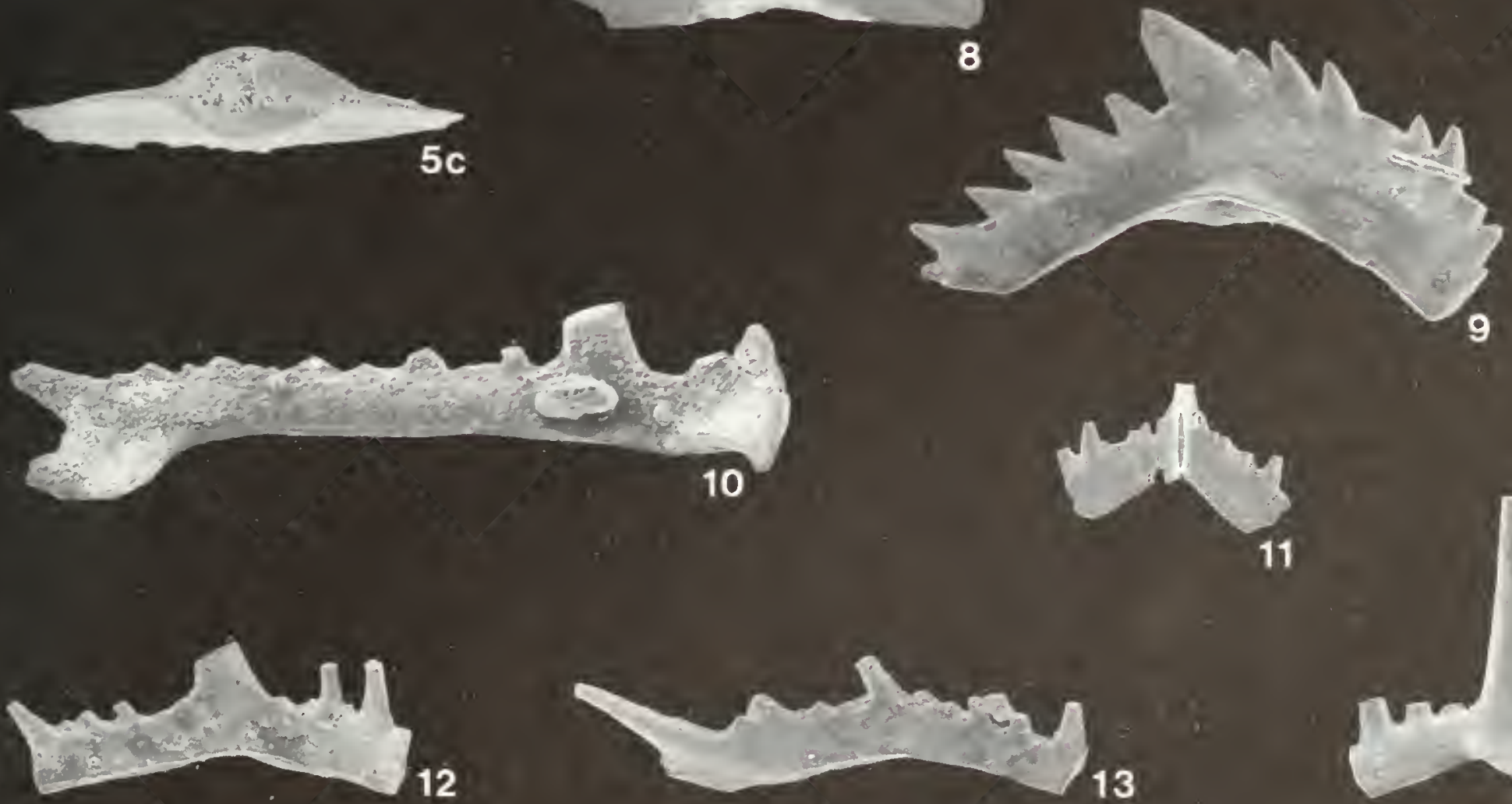
Figs. 1-5, 7. Cavusgnathus unicornis Youngquist and Miller $x 60$. $1 \mathrm{a}, \mathrm{b}$. Upper and lateral views of dextral $\mathrm{Pa} \beta / \gamma$ element $\mathrm{ROM}$ 48791, sample 88717.

2. Upper view of sinistral $\mathrm{Pa} \beta$ element $\mathrm{ROM} 48792$, sample 88776.

3. Lateral view of straight $\mathrm{Pa} \alpha$ element ROM 48793, sample 88776.

4. Lateral view of aberrant sinistral Pa element ROM 48794, sample 209862.

5. Lateral view of sinistral Pa $\gamma$ element ROM 48795, sample 209862.

7. Lateral view of M element ROM 48796, sample 209863.

Figs. 6a, b. Cavusgnathus cf. unicornis Youngquist and Miller. Upper and lateral views of dextral Pa element ROM 48797, sample LA5, x60.
Fig. 8. Cavusgnathus? sp. a. Upper view of sinistral $\mathrm{Pa}$ element ROM 48798, sample 108701, x60.

Figs. 9-15. Clydagnathus windsorensis (Globensky) x100.

9. Lateral view of dextral $\mathrm{Pa}$ element ROM 48799, sample 88758.

$10 \mathrm{a}, \mathrm{b}$. Lateral and upper views of sinistral $\mathrm{Pa}$ element ROM 48800 , sample 88757.

11. Lateral view of Pb element ROM 48801, sample 88756.

12. Lateral view of M element ROM 48802, sample 88756.

13. Posterior view of Sa element ROM 48803, sample 88756.

14. Lateral view of Sb element ROM 48804, sample 88756.

15. Lateral view of incomplete Sc element ROM 48805, sample 88756. 


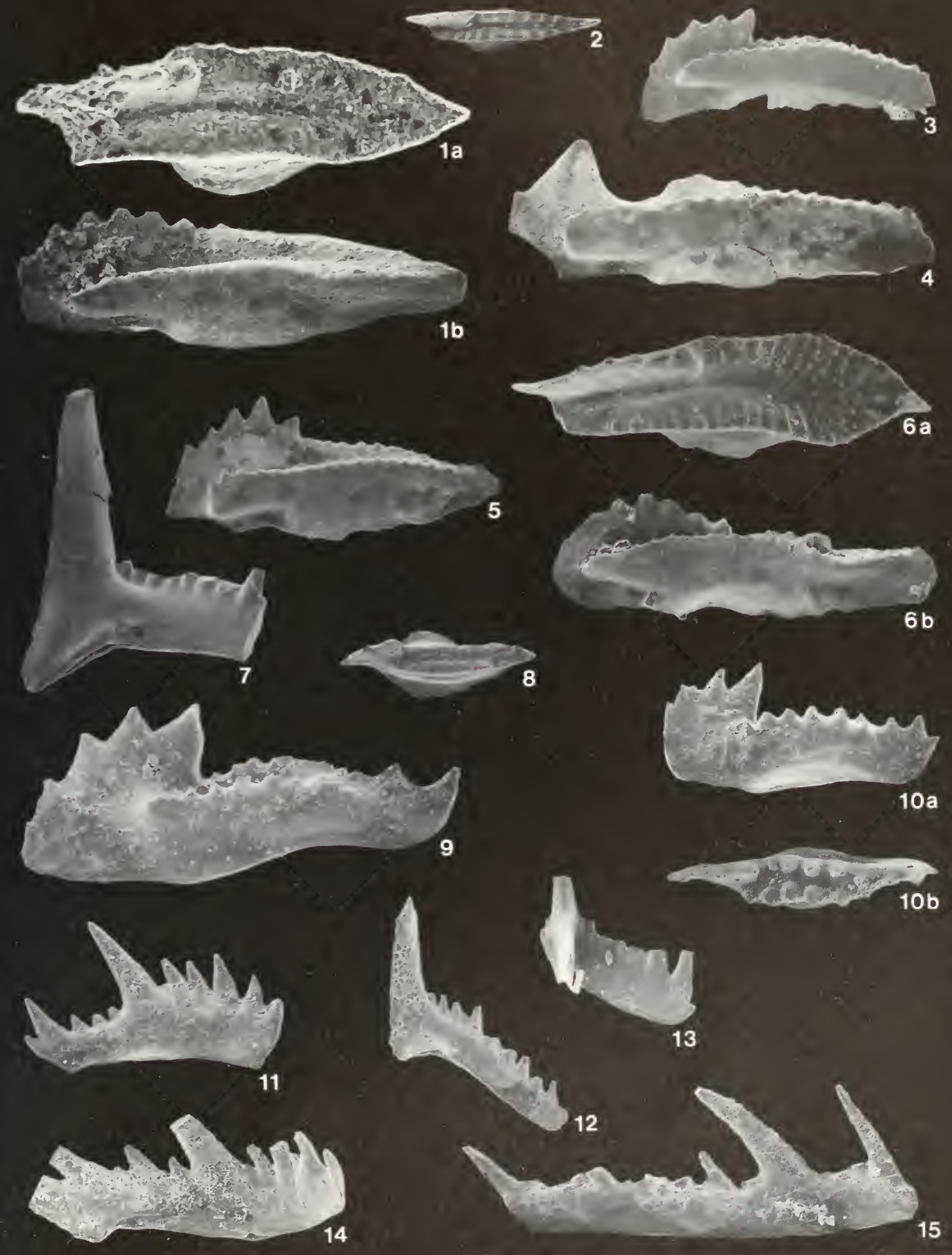


Figs. 1-9. Patrognathus capricornis (Druce) $\times 100$.

1. Lateral view of M element ROM 48806, sample 108778.

2. Upper view of Pa element ROM 48807, sample 1968710.

3a, b. Lateral and upper views of immature Pa element ROM 48813, sample 14118513.

4. Upper view of immature Pa element ROM 48814, sample 14118513.

5. Lateral view of M element ROM 48808, sample 1768701. $6 \mathrm{a}, \mathrm{b}$. Lateral and upper views of $\mathrm{Pa}$ element ROM 48809. sample 108701 .

$7 \mathrm{a}$, b. Lateral and upper views of Pa element ROM 48810 , sample 14118513.
8. Lateral view of $\mathrm{Pb}$ element ROM 48811, sample 14118517.

9. Lateral view of incomplete Sc element ROM 48812, sample 14118517.

Figs. 10-15. Taphrognathus carinatus (Higgins and Varker) $\times 80$. 10. Posterior view of Sa element ROM 48815, sample 156876. 11. Lateral view of $\mathrm{Sc}_{2}$ element ROM 48816, sample 156871.

12. Posterior/lateral view of Sb element ROM 48817, sample 196861.

13. Posterior view of Sa element ROM 48818, sample 196861. 14. Lateral view of Pb element ROM 48819, sample 196861. 15. Lateral view of M element ROM 48820, sample 196861. 


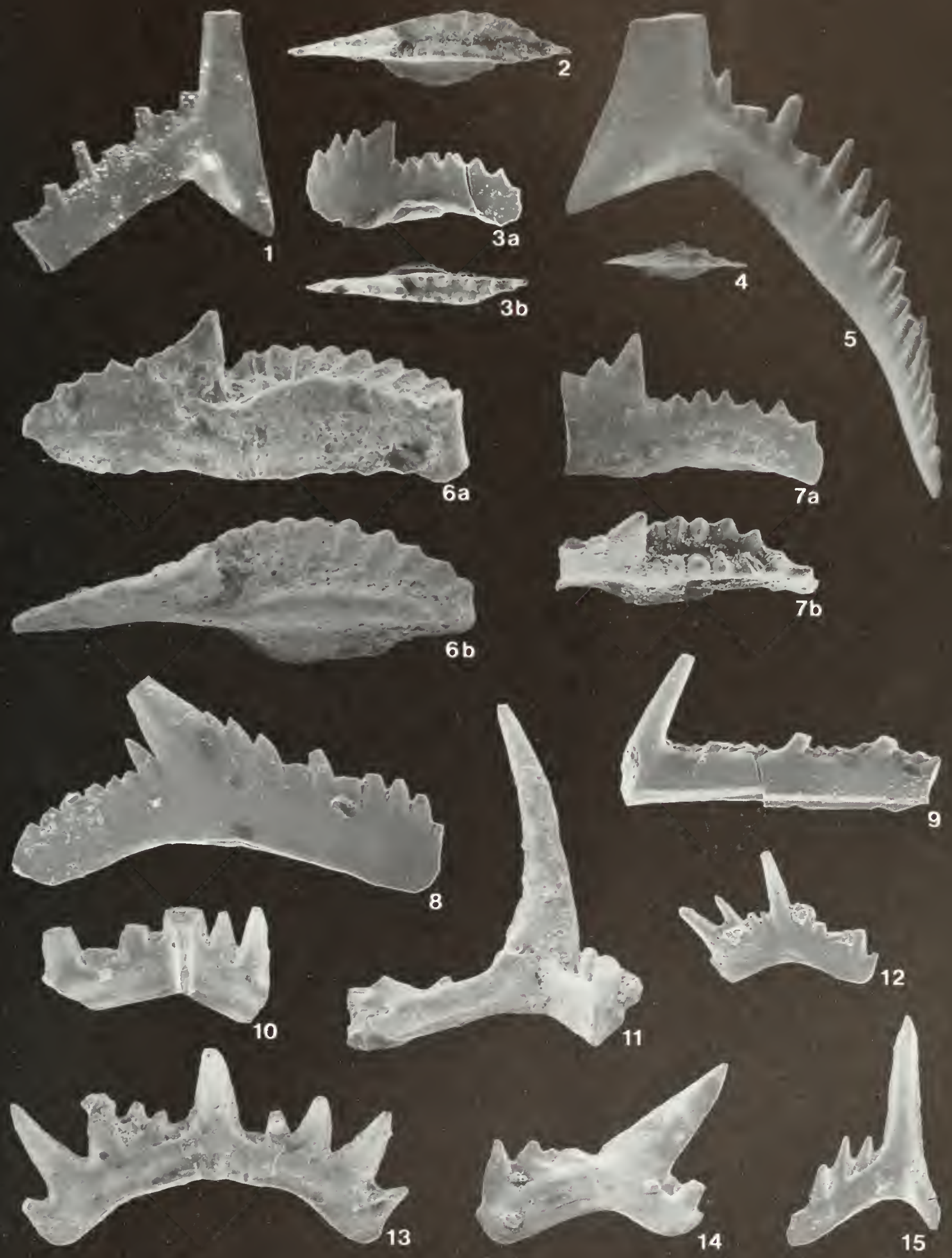


Fig. 1a, b. Taphrognathus carinatus (Higgins and Varker). Lateral and upper views of Pa element ROM 48821, sample $196861, x 80$.

Figs. 2-15. Taphrognathus varians Branson and Mehl x80.

2. Upper view of dextral morphotype II $\mathrm{Pa}$ element $\mathrm{ROM}$ 48822, sample 1768631.

3a, b. Lateral and upper views of sinistral morphotype III Pa element ROM 48823, sample 88710.

4a-c. Lateral, upper, and lower views of dextral morphotype III $\mathrm{Pa}$ element ROM 48824, sample 1768633.

5. Upper view of slightly sinuous morphotype I Pa element ROM 48825, sample 108773.

6. Upper view of dextral morphotype II/I Pa element ROM 48826 , sample 258621.
7. Upper view of immature Pa element ROM 48827, sample 1411852.

8. Lateral view of immature Pa element ROM 48828, sample 258622.

9. Upper view of dextral morphotype II Pa element ROM 48829, sample 108767.

10. Upper view of immature $\mathrm{Pa}$ element ROM 48830, sample 256866.

$11 \mathrm{a}, \mathrm{b}$. Lateral and upper views of immature $\mathrm{Pa}$ element ROM 48831, sample 258620.

12. Lateral view of $\mathrm{Pb}$ element ROM 48832, sample 1768634.

13. Lateral view of $\mathrm{Pb}$ element ROM 48833, sample 258620.

14. Lateral view of immature Pb element ROM 48834, sample 258625.

15. Lateral view of M element ROM 48835, sample 14118511. 

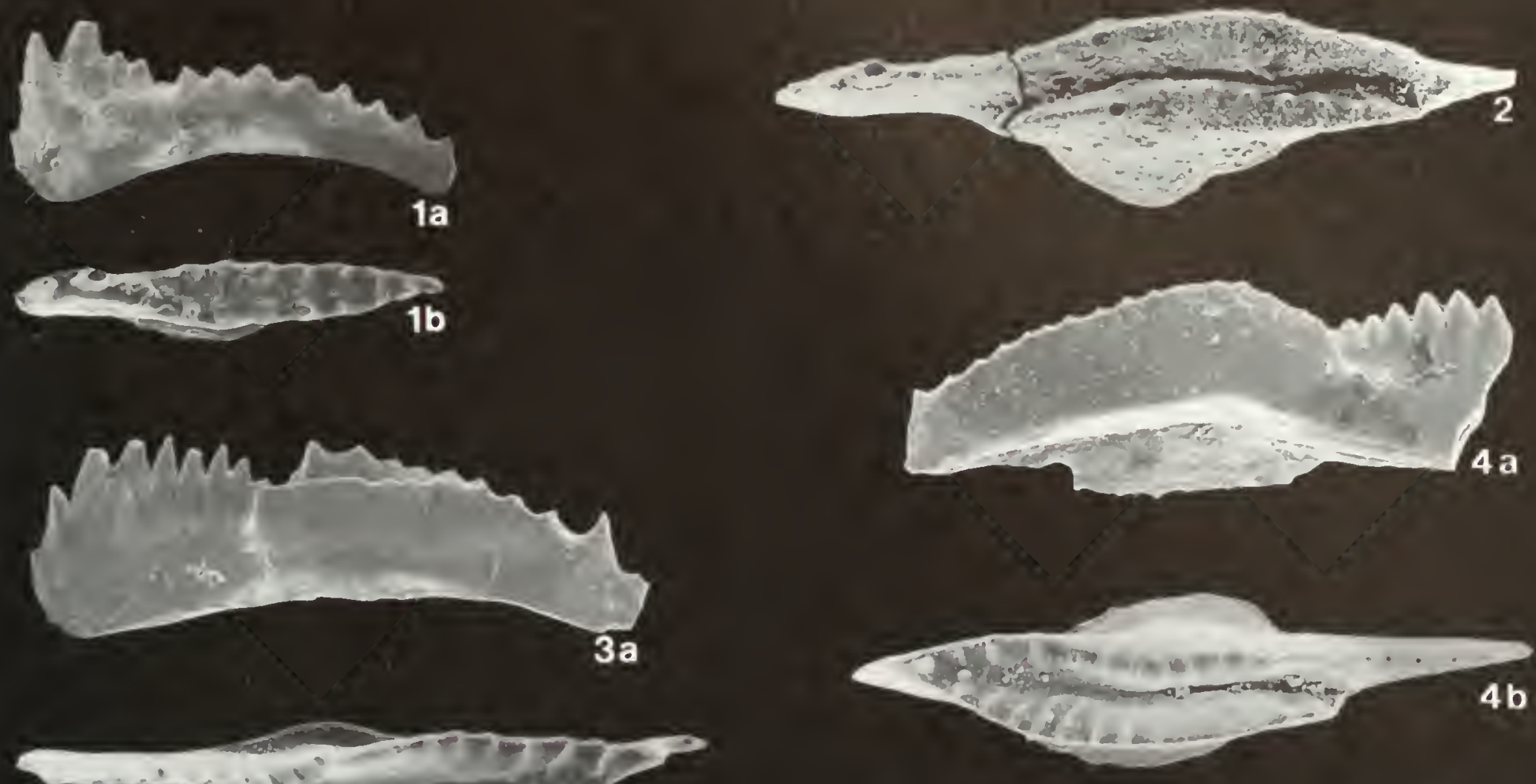

$3 b$
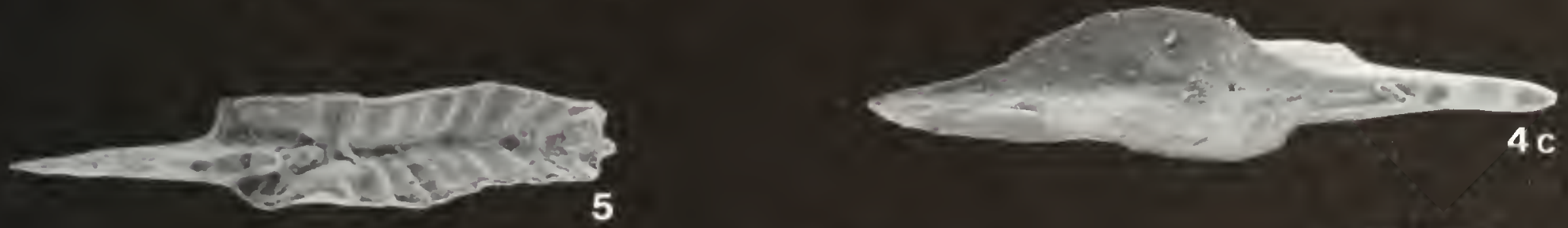

5
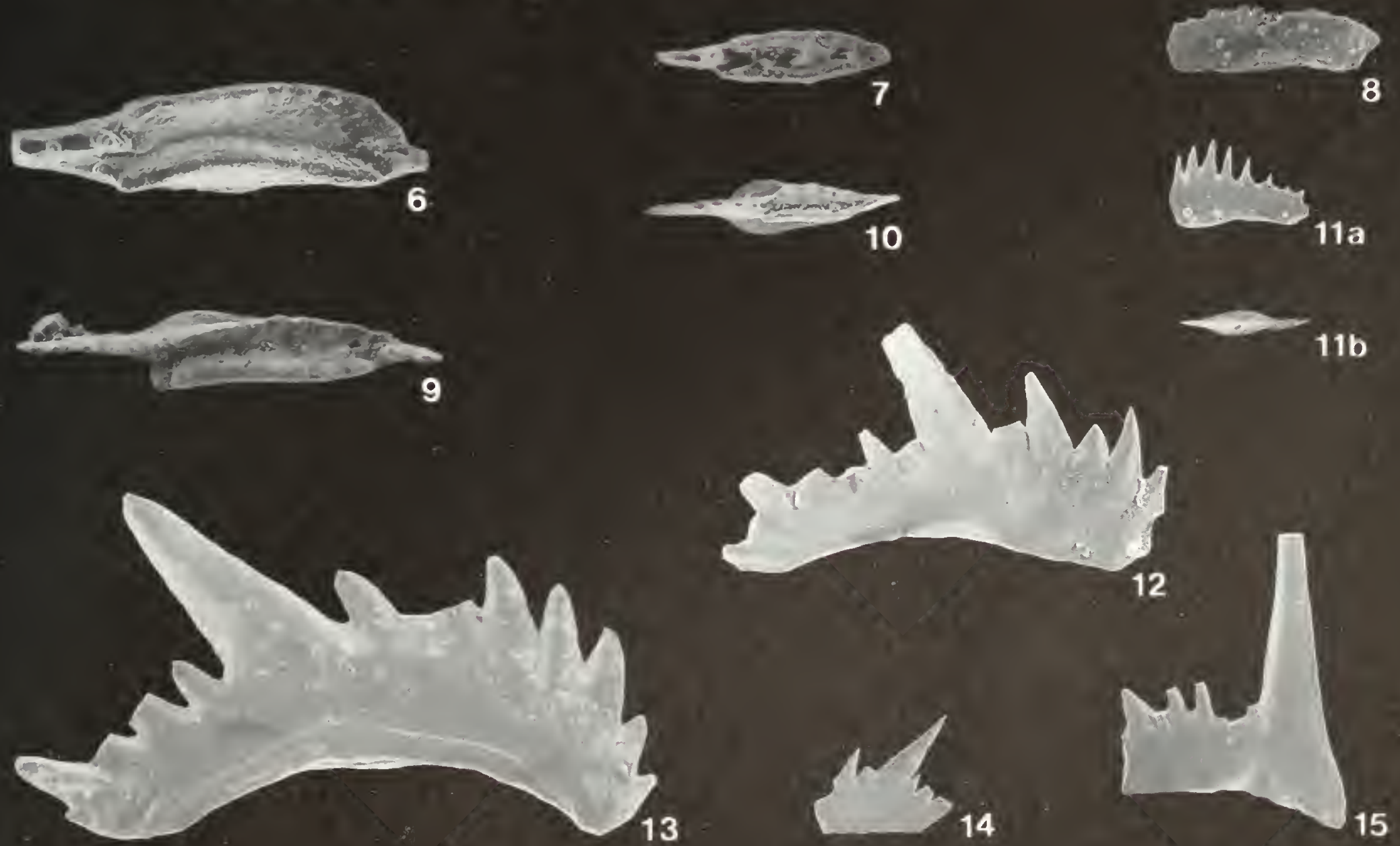
Figs. 1-3. Taphrognathus varians Branson and Mehl x80.

1. Posterior view of Sa element ROM 48836, sample 108790.

2. Lateral view of Sb element ROM 48837, sample 108790.

3. Lateral view of Sc element ROM 48838, sample 108790.

Figs. 4a, b. Taphrognathus? transatlanticus (von Bitter and Austin)?. Oblique lateral view of Pa element ROM 48839, sample 258622 , a $\times 80$, b $\times 340$.

Figs. 5a, b. Taphrognathus sp. a. Lateral and upper views of sinistral Pa element ROM 48840, sample 108745, x80.

Fig. 6. Gnathodus? simplicatus (Rhodes, Austin, and Druce). Lateral view of Pa element ROM 48841, sample 108745, x100.

Fig. 7. Gnathodus cuneiformis Mehl and Thomas. Upper view of Pa element ROM 48842, sample 196863, x100.
Figs. 8, 9. Mestognathus beckmanni Bischoff $x 60$.

$8 \mathrm{a}, \mathrm{b}$. Lower and upper views of sinistral $\mathrm{Pa}$ element ROM 48843, sample 209862.

9. Lateral view of Pb element ROM 48844, sample 258629.

Fig. 10. Mestognathus praebeckmanni Sandberg, Johnston, Orchard, and von Bitter. Oblique upper view of dextral $\mathrm{Pa}$ element ROM 48845, sample 439 of Armstrong and Pumell (1987), x60.

Figs. 11, 12. Mestognathus praebeckmanni-M. beckmanni intermediates $\times 60$.

$11 \mathrm{a}, \mathrm{b}$. Lowet and lateral views of dextral Pa element ROM 48846, sample 88750.

12a-c. Lateral, upper, and oblique lower views of dextral $\mathrm{Pa}$ element ROM 48847, sample 1768630. 

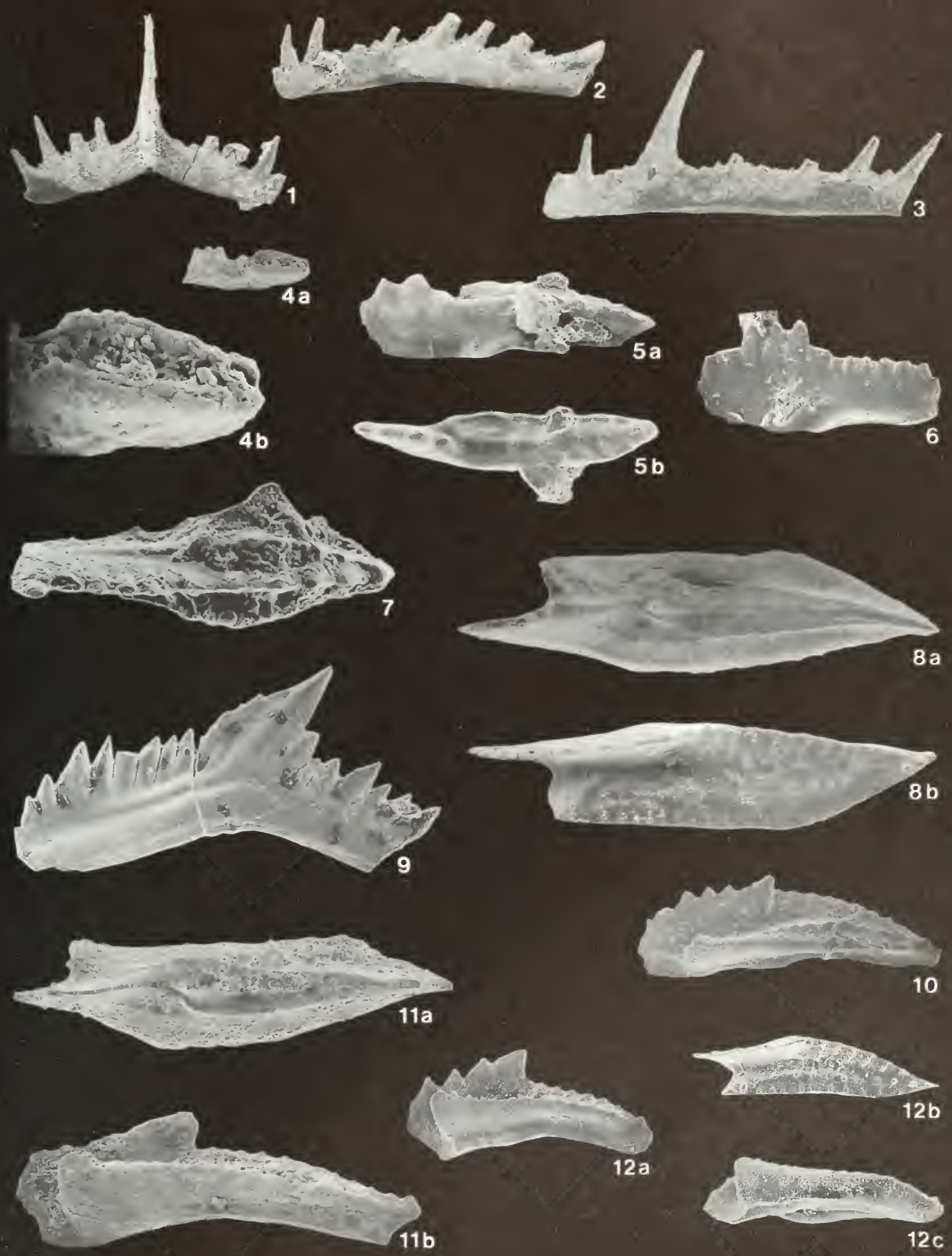
Figs. 1, 3. Polygnathus bischoffi Rhodes, Austin, and Druce $\times 80$. 1. Upper view of Pa element ROM 49848, sample 88751.

3. Lower view of Pa element ROM 48849, sample 88750.

Figs. 2, 4-7, 9-11. Polygnathus mehli Thompson $x 80$.

2. Oblique upper view of $\mathrm{Pa}$ element ROM 48850 , sample 108760.

4. Lower view of Pa element ROM 48851, sample 108745.

5. Lateral view of M element ROM 48852, sample 108763.

6. Lateral view of Pb element ROM 48853, sample 108763.

7. Lateral view of $\mathrm{Pb}$ element ROM 48854, sample 108763.

9. Lateral view of Sc element ROM 48855, sample 108763. 10a, b. Posterior and oblique lateral views of Sa element ROM 48856, sample 108763.

11. Lateral view of Sc element ROM 48857, sample 108763.

Fig. 8. Polygnathus sp. Lateral view of immature Pa element ROM 48858, sample 108745, x80.

Figs. 12a, b. Lochriea scotiaensis (Globensky). Lower and lateral views of $\mathrm{Pa}$ element ROM 48859, sample 88760, x100.

Fig. 13. Lochriea sp. Lateral view of M element ROM 48860 , sample 209863, x60. 

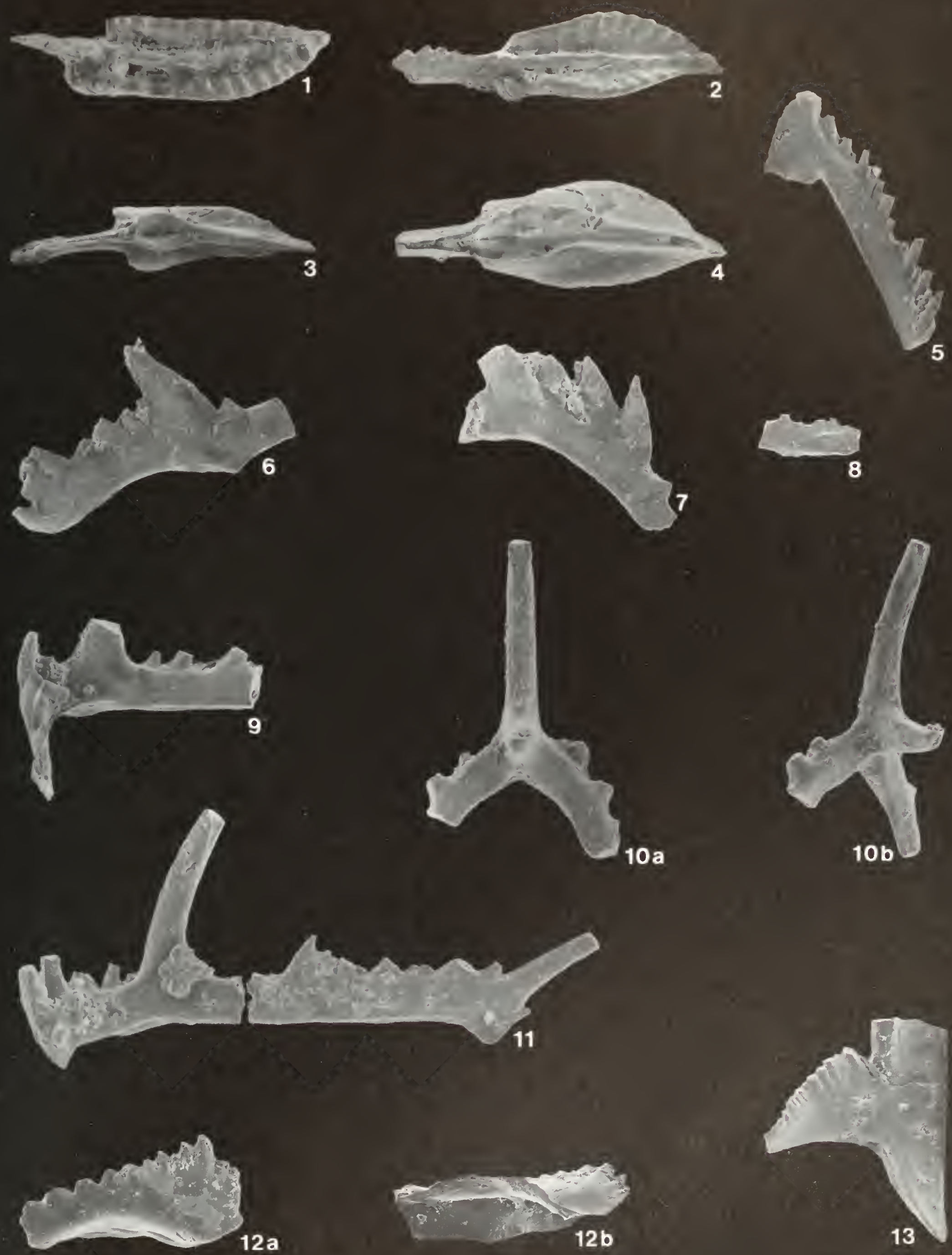
PLATE 7, FIGS. 1-12

Figs. 1-8. Vogelgnathus gladiolus Purnell and von Bitter x 180 .

1a, b. Lateral and upper views of $\mathrm{Pa}$ element ROM 48667, sample 258624.

2. Lateral view of Pa element ROM 48668, sample 258622.

3. Lateral view of variant $\mathrm{Pa}$ element ROM 48861, sample 1768636.

4. Oblique lower view of $\mathrm{Pa}$ element ROM 48669, sample 14118517.

5. Lateral view of Sb element ROM 48672, sample 1768634.

6. Lateral view of Sc element ROM 48675, sample 14118517

7. Lateral view of $\mathrm{Pb}$ element ROM 48674, sample 1768635.
8. Lateral view of M element ROM 48673, sample 258622.

Figs. 9, 10, 12. Vogelgnathus kyphus Purnell and von Bitter x180.

9. Upper view of Pa element ROM 48676, sample 88727.

$10 \mathrm{a}-\mathrm{c}$. Lateral, lower, and upper views of $\mathrm{Pa}$ element ROM 48677, sample 88725 .

12. Lateral view of Sb element ROM 48679, sample 88726.

Figs. 1la, b. Vogelgnathus pesaquidi Purnell and von Bitter. Lateral and lower views of morphotype II Pa element ROM 48683, sample $1768701, \times 180$. 

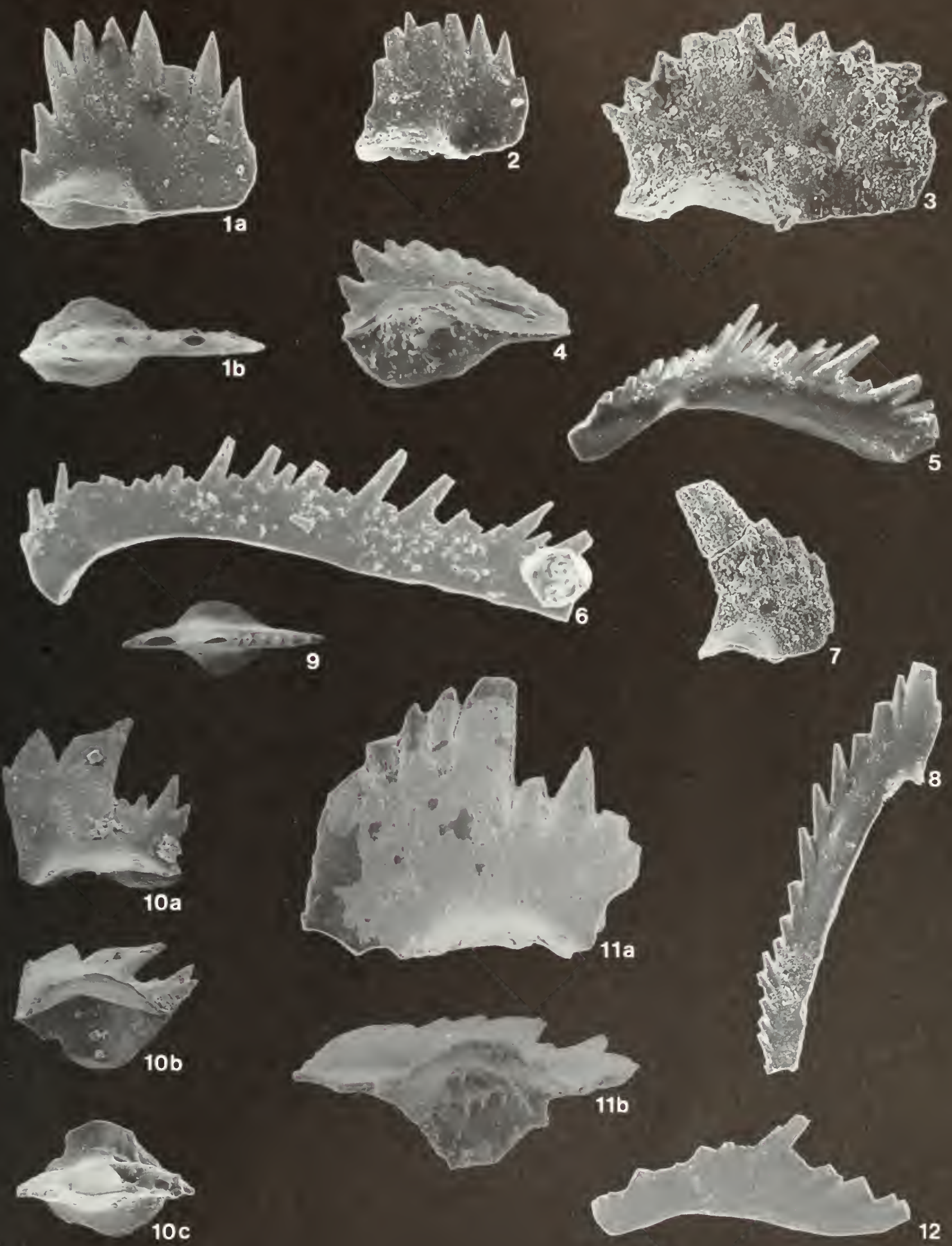
Fig. 1. Vogelgnathus cf. pesaquidi Purnell and von Bitter. Lateral view of Pa element ROM 48862, sample 256862, x180.

Figs. 2, 3. Kladognathus tenuis (Branson and Mehl) x80.

2a, b. Lower posterior and oblique lateral views of Sa element ROM 48863, sample 88754.

3. Lateral view of Sc $\alpha$ element ROM 48864, sample 88754.

Figs. 4-9. "Apatognathus" cuspidatus Varker x100.

4. Posterior? view of Sa element ROM 48865, sample 108790.

5. Posterior? view of Sa element ROM 48868, sample 108768.
6. Lateral view of Sb element ROM 48866, sample 14118513.

7. Lateral view of Sc element ROM 48867, sample 108768.

8. Lateral view of Pa element ROM 48869, sample 108767.

9. Lateral view of Pb element ROM 48870, sample 108767.

Fig. 10. "Apatognathus" sp. Lateral view of Pa element ROM 48871, sample $1768702, \times 100$.

Figs. 11, 12. Gen. a sp. a x100.

11. Lateral view of Pa element ROM 48872, sample 88776.

12. Lateral view of $M$ element ROM 48873, sample 88776. 

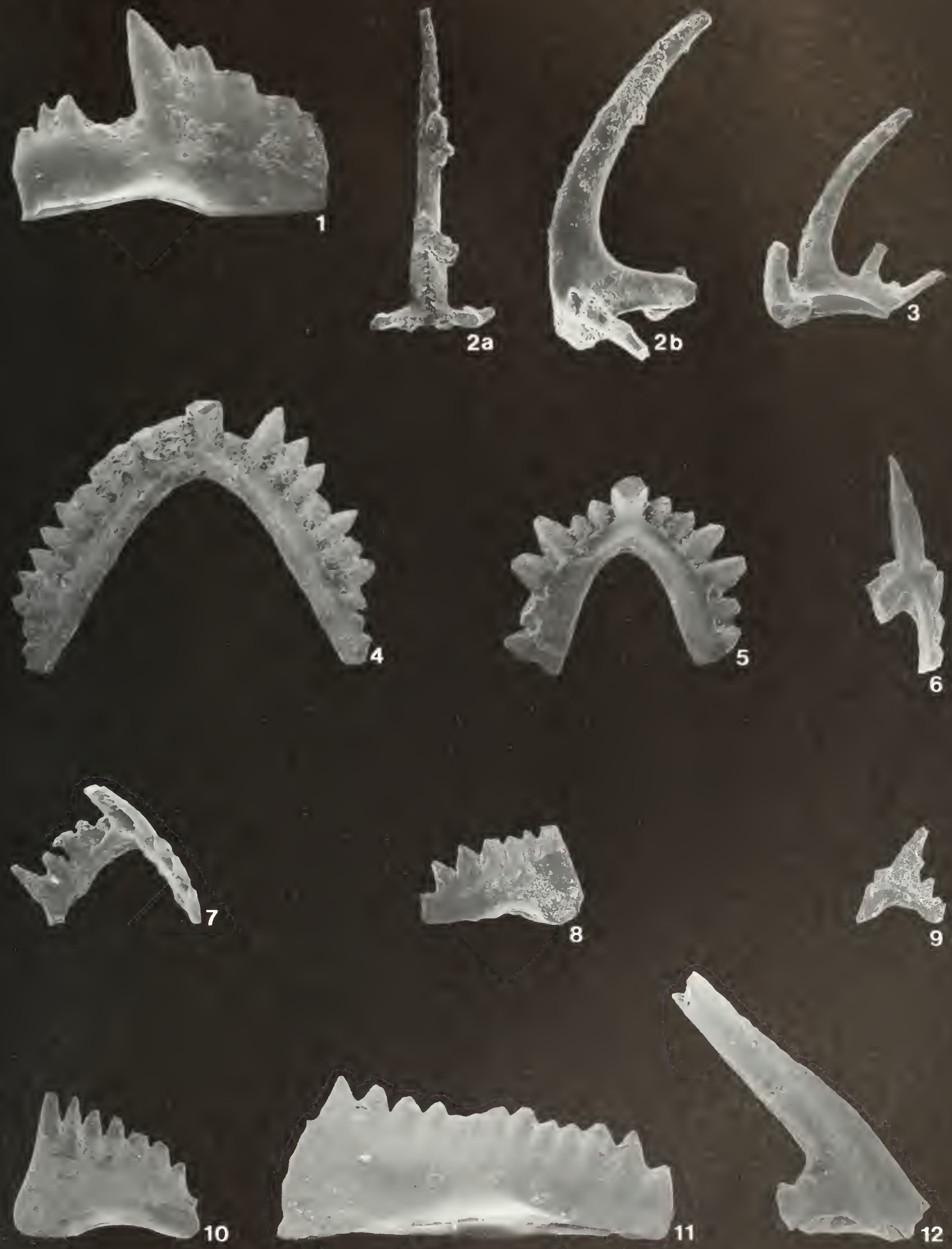


\section{ROYAL ONTARIO MUSEUM LIFE SCIENCES PUBLICATIONS INSTRUCTIONS TO AUTHORS}

Authors should prepare their manuscripts carefully according to the following instructions; failure to do so will result in the manuscript's being returned to the author for revision. All manuscripts are considered on the understanding that they are not currently offered for publication elsewhere.

1. General Papers for publication are accepted from ROM staff members and research associates, and from researchers reporting on work done with ROM collections. Monographs on the flora and/or fauna of Ontario by authors not affiliated with the ROM may be considered for publication. Financial contributions towards publication may be required. Authors are expected to write clearly and concisely and to omit any material not essential for an understanding of the main theme of the paper.

2. Format Manuscripts (including captions, synonymies, literature cited, and tables) should be typed double-spaced on standard letter-size paper with a $4-\mathrm{cm}(1)$ margin on all sides. Three photocopy copies should be submitted to the Head of Publications and Print Services; the original should be retained by the author. The submission should include a separate sheet giving the author(s) names and affiliations, the title of the publication, the series if applicable, the number of typed pages, the number of tables, and the number of plates and figures. Manuscripts should normally be organized in the following order: contents, abstract, introduction, materials and methods, results, discussion, conclusions, summary (if manuscript is long), acknowledgments, appendices, and literature cited. Authors are encouraged to include foreign-language translations of the summary, if appropriate. Main headings should be centred; subheadings should be left-justified to the text margin. The first line of the first paragraph in each new section should not be indented. Literature citations in the text should be in one of the following forms: "Jones (1972)" or "(Jones, 1972)" or "(Smith, 1960:71-79, fig. 17)."

3. Standard Sources The primary authority on questions of format and style is the Guide to Authors and Editors, available from ROM Publications and Print Services. For matters not covered in the guide, consult the CBE Style Manual. Other standard sources are as follows: for English spelling, The Concise Oxford Dictionary; for Canadian place names and coordinates, Canada Gazetteer Allas; for the spelling of geographic names, The Times Allas of the World.

4. Abstract All papers must be preceded by a short, factual abstract, about one per cent of the text in length. The abstract may be followed by four to six key words in parentheses.

5. Taxonomy The name of a taxon should be given in full in headings, at the beginnings of paragraphs, and at its first occurrence in the text. Give the authority and date, if appropriate, with the first mention of each taxon, but not thereafter. Taxonomic papers, particularly synonymies, should follow the layout in the Guide to Authors and Editors. International Codes of Biological Nomenclature must be followed.

6. Literature Cited A complete list of references, in alphabetical order of authors, must be given at the end of the paper. When two or more works of one author are cited, they should be listed chronologically. The names of journals should not be abbreviated. For correct bibliographic form, see the Guide to Authors and Editors.

7. Tables All tables should be typed on separate sheets and numbered consecutively in arabic numerals in the order of their first mention in the text. Mark the location of each table in the margin of the text.

8. Plates, Figures, and Text-figures Illustrations may be designated according to the conventions of the author's discipline; in some disciplines grouped photographs of scientific subject matter are commonly termed Plates, while line drawings and locality and other illustrations that occupy a full page or less are Text-figures. Usage must be consistent throughout the paper. A full-page illustration with its caption should be sized to fit an area of $17.3 \times 22.75 \mathrm{~cm}\left(6.8^{-} \times 9^{7}\right)$ for a Contribution; for Occasional Papers, the area is 14.1 $x 21.2 \mathrm{~cm}\left(5.5^{\circ} \times 8.3^{7}\right)$. If captions are lengthy, they may be placed on the facing page. A scale or magnification factor should be included. Authors are reminded that when illustrations are reduced, magnification factors will change, and that they are responsible for the conversion. For details, see the Guide to Authors and Editors. 


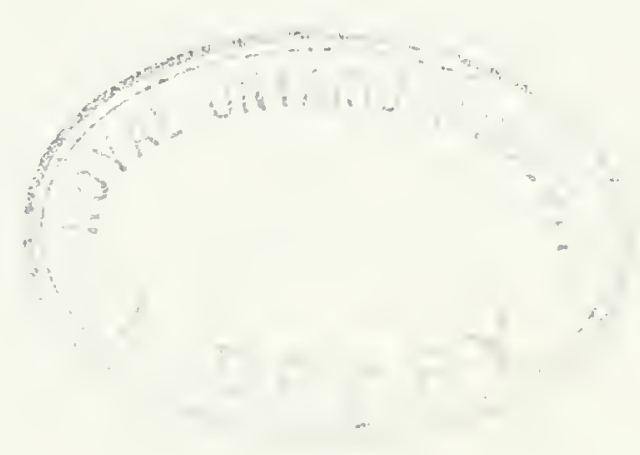




\section{ROYAL ONTARIO MUSEUM LIFE SCIENCES PUBLICATIONS}

Life Sciences Contributions are a numbered series of scientific publications of varied subject matter. Most recent contributions include the following:

155 Revision of the World Species of Spalangiopelta (Hymenoptera: Chalcidoidea: Pteromalidae: Ceinae)

D. Christopher Darling 1991, 48 pp., ill., \$11.00, ISBN 0-88854-395-6

154 Shallow-Water Hydroids of Bermuda: The Thecatae, Exclusive of

Plumularioidea

Dale R. Calder

1991, 144 pp., ill., \$24.50,

ISBN 0-88854-354-9

153 Silurian Trilobites from the Northern Yukon Territory

Rolf Ludvigsen and Ronald P. Tripp

1990, 64 pp., ill., \$12.95,

ISBN 0-88854-349-2

152 The Type Species of the Ordovician Trilobite Genus Isotelus: I. gigas Dekay, 1824

David M. Rudkin and Ronald P. Tripp 1989, 24 pp., ill., \$10.25,

ISBN 0-88854-345-X

151 The Structure of the Call Note System of the Warbling Vireo

Daryl Howes-Jones and Jon C. Barlow

1988, 40 pp., ill., \$11.00,

ISBN 0-88854-343-3

150 Late Cretaceous-Early Tertiary

Dinoflagellates and Acritarchs from the Kashi Area, Tarim Basin, Xinjiang

Province, China

Mao Shaozhi and Geoffrey Norris

1988,100 pp., ill., \$25.00,

ISBN 0-88854-334-4

149 Occurrence of the Cladid Inadunate

Crinoid Thalamocrinus in the Silurian

(Wenlockian) of New York and Ontario George C. McIntosh and Carlton E. Brett 1988, 20 pp., ill., \$7.75, ISBN 0-88854-342-5
148 Shallow-Water Hydroids of Bermuda:

The Athecatae

Dale R. Calder

1988, 112 pp., ill., $\$ 24.50$,

ISBN 0-88854-339-5

\section{Related titles published by the Royal Ontario Museum:}

The Reconstruction of Fossil Organisms Using Cluster Analysis: A Case Study from Late Paleozoic Conodonts Peter H. won Bitter and Glen K. Merrill 1990, 32 pp., ill., $\$ 8.00$, ISBN 0-88854-352-2

LSC 143 Phylogeny, Speciation, and Palaeoecology of the Early Carboniferous (Mississippian) Conodont Genus Mestognathus

Peter H. von Bitter, Charles A. Sandberg, and Michael J. Orchard 1986,120 pp., ill., $\$ 25.00$, ISBN 0-88854-319-0

LSC 136 Late Palaeozoic Species of Ellisonia (Conodontophorida):

Evolutionary and Palaeoecological Significance

Peter H. von Bitter and Glen K. Merrill 1983, 64 pp., ill., \$7.50, ISBN 0-88854-294-1

LSC 106 Conodont Ultrastructure: The Subfamily Acanthodontinae C. R. Barnes and D. J. Slack 1975, 24 pp., ill., \$3.95, ISBN 0-88854-179-1

A catalogue of ROM publications in print is available from

University of Toronto Press 10 St. Mary Street, Suite 700 Toronto, Ontario M4Y 2W8 Canada

Tel. (416) 978-2229 Fax (416) 978-4738

ISBN 0-88854-405-7 ISSN 0384-8159 